\title{
G:3 TSP
}

Estudo elínico e radiográfico

comparativo entre o Formoeresol de

Buckley a 1/5, Hidróxido de eáleio P.Al. e

Hidróxido de eáleio P.Al. preceedido por

antiinflamatório para pulpotomia em

dentes decíduos humanos

Matalino Lourence Heto

Dissertação apresentada à Faculdade de Odontologia de Bauru, da Universidade de São Paulo, como parte dos requisitos para obtenção do título de mestre em Odontologia, na área de Odontopediatria.
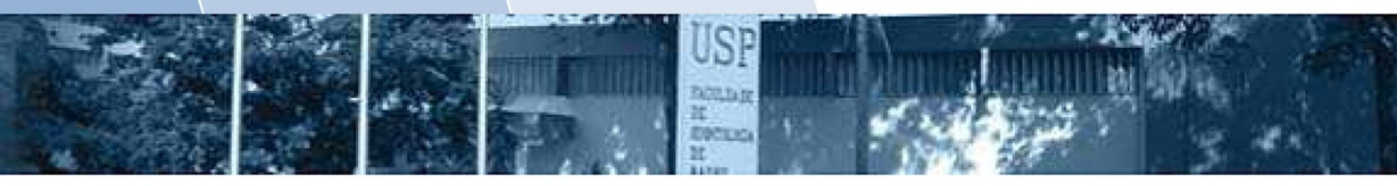


\section{G:3 TSP}

Estudo clínico e radiográfico

eomparativo entre o Formoeresol de Buekley a 1/5, Hidróxido de eáleio P.A. e Hidróxido de eáleio P.A. preeedido por antiinflamatório para pulpotomia em dentes decíduos humanos

Matalino Loureneco Heto

Dissertação apresentada à Faculdade de Odontologia de Bauru, da Universidade de São Paulo, como parte dos requisitos para obtenção do título de mestre em Odontologia, na área de Odontopediatria.

Orientador: Prof. Dr. Ruy César Camargo Abdo
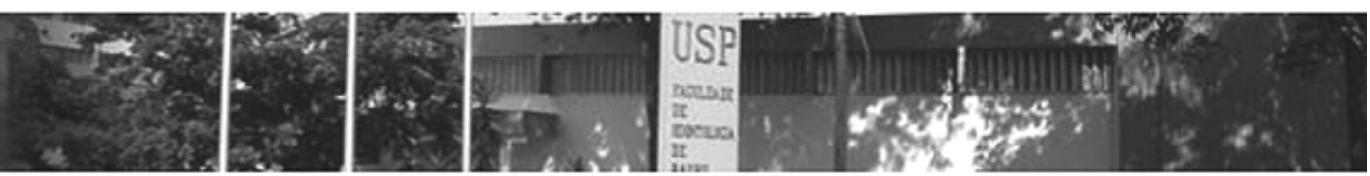


\begin{tabular}{|l} 
Lourenço Neto, Natalino \\
L934e Estudo clínico e radiográfico comparativo entre o \\
Formocresol de Buckley a 1/5, Hidróxido de cálcio P.A. \\
e Hidróxido de cálcio P.A. precedido por \\
antiinflamatório para pulpotomia em dentes decíduos \\
humanos / Natalino Lourenço Neto. -- Bauru, 2008. \\
144 p.: il. ; $30 \mathrm{~cm}$. \\
Dissertação (Mestrado) -- Faculdade de \\
Odontologia de Bauru. Universidade de São Paulo. \\
Orientador: Prof. Dr. Ruy César Camargo Abdo
\end{tabular}
Autorizo, exclusivamente para fins acadêmicos e científicos, a reprodução total ou parcial desta dissertação, por processos fotocopiadores e outros meios eletrônicos.

Assinatura:

Data:

Comitê de Ética da FOB-USP
Protocolo $\mathrm{n}^{\mathrm{0}}: 62 / 2007$
Data:30/05/2007




\section{DતADOS CURRICULARES}

\section{Matalino Lourenço Neto}

Nascimento

Naturalidade

Filiação

2003 - 2006

2007 - 2009
01 de Setembro de 1982

Bauru - SP

Natalino Lourenço J unior Alice Ferreira Lourenço

Curso de Graduação em Odontologia pela Faculdade de Odontologia de Bauru Universidade de São Paulo

Curso de Pós-graduação em Odontologia, nível de Mestrado, Área de Odontopediatria, pela Faculdade de Odontologia de Bauru - Universidade de São Paulo 


\section{AGRADECIMENTOS}

A DEUS, pela sua presença em todos os momentos durante esta nova jornada, pelo conforto encontrado na oração quando dos momentos dificeís. Pela família, saúde e príncípalmente pela vída que me concedeu.

"Abra os olhos para ver as coisas como realmente são Basta apenas acreditar em você mesmo e esperar em Deus

Considere as coisas por vários ângulos

Desistir e entregar-se jamais

Entenda a si mesmo para compreender melhor seus semelhantes

Família e amigos são tesouros escondidos, procure encontrá-los e desfrutar de suas riquezas

Ganha mais quem faz e doa."

Autor Desconhecido

Aos meus yaís, Natalino Junior e Alice, que me deram a vída e os ensinamentos de caráter e de como vivê-la com dignídade. verdadeíras luzes no caminho e exemplos a ser seguído. País que se doaram ao máximo para que maís essa realização em mínha vída fosse alcançada. Mínha gratídão yor vocês não tem tamanho. Obrigado pelo amor incondicional que vocês têm por mím.

"Os passos apoiados na infância, os conselhos proferidos na adolescência são esses os ensinamentos de toda a Vida."

Publílio Siro 
Ao meu querído írmão, Rogério, você é e sempre será meu "corneta", suas bríncadeíras e amizade são muíto importantes em minha vída. Contínue sempre sendo esse írmão maravilhoso.

"O afeto conduz a alma, como os pés conduzem o corpo."

Santa Catarina de Siena

A minha noivva, Mariana, seu amor e carínho são as forças eternas que tereí jara seguír qualquer que seja a jornada. Ter você ao meu lado como companheíra é saber que conto com uma pessoa forte e maravilhosa para seguír. Obrigado pelas inúmeras vezes que me escutou com um colo amoroso e me incentívou a seguír.

"Por você ter gostado de mim

Do jeito que sou...

Por ter me aceitado

Com meus defeitos

E por saber também

Elogiar minhas virtudes.

Por me ensinar

Que a cada dia

Podemos recomeçar

Por me fazer sentir

Um alguém diferente

E por eu saber

Que sempre contigo

Poderei contar."

Autor Desconhecido

Amo Você!!! 
Aos meus amigos, em especial Marcelo Zanín, Matheus, Mario, Augusto, Octavio, Tiago (Camarão) e Marina, yela verdadeíra amizade e companheírismo em todos os momentos. Valeu pelas conversas e incentívos a seguír com força essa jornada.

"Eu poderia suportar, embora não sem dor, que tivessem morrido todos os meus amores, mas enlouqueceria se morressem todos os meus amigos."

Vinícius de Moraes

Aos meus colegas de mestrado, Adriana, carla, cristiane, Junia, Marco Aurélio, Tatíana e Ana Paula, a convivêncía com vocês durante esses anos me trouxe inúmeras experiêncías novas e positivas, que me acompanharam pela vída toda. Cada um de vocês contribuíu de alguma forma para a conclusão desse trabalho.

Um agradecimento especial ao amigo desde a graduação Marco Aurélio, pela convivêncía maís próxima e pelo ombro amígo sempre ao meu dispor para ajudar. Valeu parceíro!!

"Todo meu patrimônio são meus amigos"

Emily Dickinson

Aos colegas do doutorado, Vivien, Thaís, Tiza, Thiago, Juliana e claudia, obrigado gela amizade e por estarem sempre presentes com seu conhecimento maís apurado a ajudar um novato.

Um agradecimento especial a hoje Professora Tiza, que me iniciou neste trabalho, guíando minha mão nas prímeíras pulyotomías.

"A única maneira de ter um amigo é sendo um."

Ralph Waldo Emerson 
Aos professores da Dísciplina de Odontopediatría da FOB - USP, obrigado por serem verdadeíros mestres e amigos.

Prof $^{\natural}$ Dr $^{\natural}$ Salete Moura Bonifácio da Sílva - Dedicada, sua dedicação para com os alunos e pacientes é invejável.

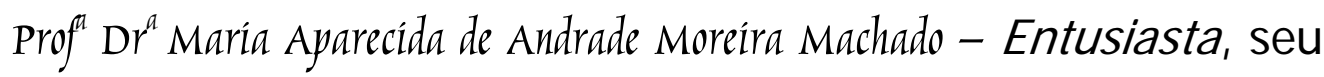
entusiasmo e crença no futuro melhor da Odontologia é contagiante. Você sabe como motivar as pessoas! Prof $^{\natural}$ Dr $^{a}$ Daníela Ríos - Esforçada, seu constante esforço na pesquisa e agora na docência são exemplos a serem seguidos.

Prof Dr José Eduardo de oliveíra Lima - Desafiador, seus conceitos daquilo que parecem exato desafiam e nos levam sempre a refletir.

Meus especiais agradecimentos ao meu orientador, Prof Dr Ruy César Camargo Abdo, obrigado por me aceitar como seu orientado, um garoto recém-formado, obrigado por realmente me orientar dentro do mundo da Odontología. Nossas conversas e seus ínúmeros conselhos ficarão na memóría para sempre. Seu exemplo de determínação sabedoría e caráter, príncípalmente como pai foí, são e serão ínesquecíveís em minha vída. Sem notar, do seu jeíto simples, você fez parte do meu amadurecimento, e tenho certeza que ganhei um grande amigo.

"No que diz respeito ao desempenho, ao compromisso, ao esforço, à dedicação, não existe meio termo. Ou você faz uma coisa bemfeita ou não faz."

Ayrton Senna 
Meu muíto obrigado aos funcionáríos do Departamento de Odontopediatría, Lía, Liliam, Estela, Fátíma, por toda a doação e auxílio com meus yacientes, apoío e boas íntenções. A dedícação, paciêncía e boa vontade demonstrada por essa equípe, sempre sorríndo, é inigualável. Essa conquista é de vocês também. Obrigado pelo convívio diárío e pela amizade.

Ao Prof Dr José Roberto Pereira Lauris, da discíplina de Saúde coletiva da FOB - USP, pelo auxílio na realização da análise estatística. Obrigado yor me atender fora de hora...

Aos Funcionários da Bíblioteca e do Servíço de Documentação da FOB - USP, sempre prontos a ajudar e por toda a atenção durante todos esses anos.

Aos Funcionáríos da Pós-Graduação FOB - USP, pelo auxílio nos problemas e assuntos burocrátícos.

A todas as pessoas que direta ou indiretamente e de maneíra não menos ímportante colaboraram yara a realização deste trabalho. 


\title{
Agradecimentos Institucionaís
}

\begin{abstract}
À Faculdade de Odontología de Bauru, Uníversídade de São Paulo, FOB - USP, representada pelo diretor Prof Dr Luís Fernando Pegoraro.
\end{abstract}

À comissão de Pós-Graduação da Faculdade de Odontología de Bauru, Univversidade de São Paulo, FOB - USP, representada pela presidente Prof ${ }^{\mathfrak{a}} \mathrm{Dr}^{\mathfrak{a}}$ María Aparecida de Andrade Moreira Machado. 
As verdadeirras conquistas, as únícas de que nunca nos arrependemos,

são aquelas que fazemos contra a ígnorâncía.

Albert Einstein 


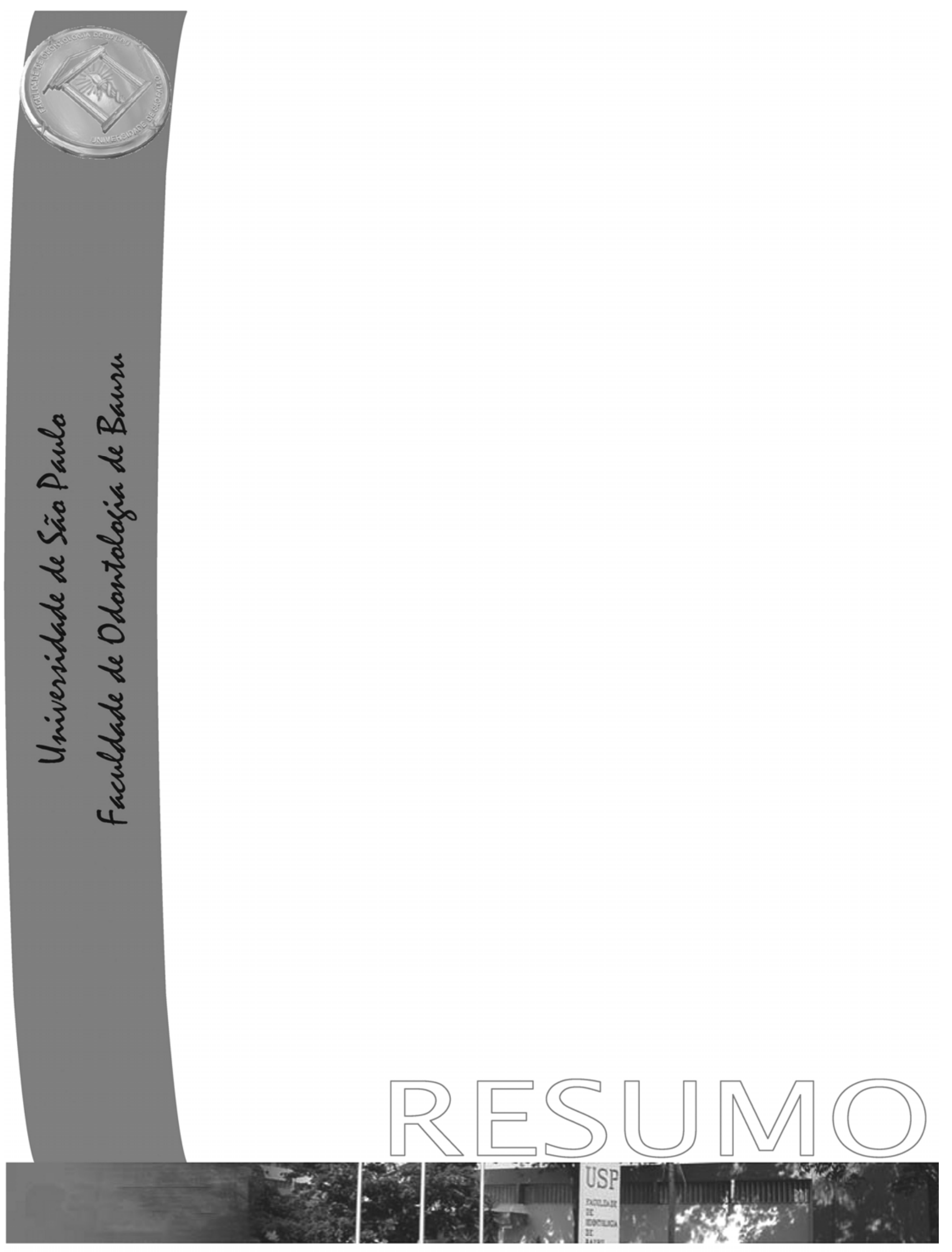




\section{RESUIHO}

O objetivo deste estudo foi comparar a eficácia clínica e radiográfica do formocresol de Buckley diluído a 1/5, do Hidróxido de cálcio e do Hidróxido de cálcio precedido de um medicamento antiinflamatório o Otosporin ${ }^{\circledR}$ como agentes capeadores pulpares em dentes decíduos humanos acometidos por cárie extensa. Quarenta e cinco molares decíduos inferiores de 35 crianças com idades entre 5 e 9 anos foram criteriosamente selecionados. Os dentes foram aleatoriamente divididos nos grupos formocresol, hidróxido de cálcio ou hidróxido de cálcio precedido de antiinflamatório e tratados pela técnica convencional de pulpotomia em uma única sessão. Após a remoção da polpa coronária e hemostasia, no grupo do formocresol, uma bolinha de algodão embebida na solução foi colocada por 5 minutos sobre o remanescente pulpar e então a câmara pulpar preenchida com óxido de zinco e eugenol. Para o grupo hidróxido de cálcio, o pó foi acomodado sobre o remanescente pulpar com o auxílio de um porta amálgama estéril. No terceiro grupo uma bolinha de algodão embebida em Otosporin ${ }^{\circledR}$ foi colocada por 5 minutos sobre o remanescente pulpar e em seguida o pó de hidróxido de cálcio foi acomodado sobre o remanescente pulpar com o auxílio de um porta amálgama estéril. Todos os dentes foram restaurados com uma base de óxido de zinco e eugenol reforçado (IRM) e cimento de ionômero de vidro modificado por resina $\left(\right.$ Vitremer $\left.^{\circledR}\right)$. As avaliações clínicas e radiográficas foram realizadas nos períodos de 3, 6 e 12 meses do pós-operatório. Dos 45 dentes apenas 43 foram avaliados nos períodos de 3 e 6 meses, devido a desistência de 2 crianças, e aos 6 meses 2 dentes do grupo hidróxido de cálcio necessitaram ser extraídos devido falha clínica. Aos 12 meses, 7 dentes não puderam ser avaliados (3 dentes esfoliaram naturalmente e 4 dentes necessitaram ser extraídos devido falha clínica). Nenhum sinal de falha clínica ou radiográfica foi observado no grupo formocresol em todos os períodos avaliados. Os demais grupos estudados apresentaram reabsorções internas já aos 3 meses de controle pós-operatório, assim como a presença de barreira dentinária também foi observada já nesse período, e o grupo hidróxido de cálcio foi o único a apresentar falhas clínicas. O uso de um antiinflamatório parece auxiliar para um maior índice de sucessos clínicos quando do uso de hidróxido de cálcio em pulpotomias de dentes decíduos, pois esta se mostrou uma técnica extremamente sensível.

Palavras-chave: Pulpotomia. Dente decíduo. Formocresol. Hidróxido de cálcio. Antiinflamatório 


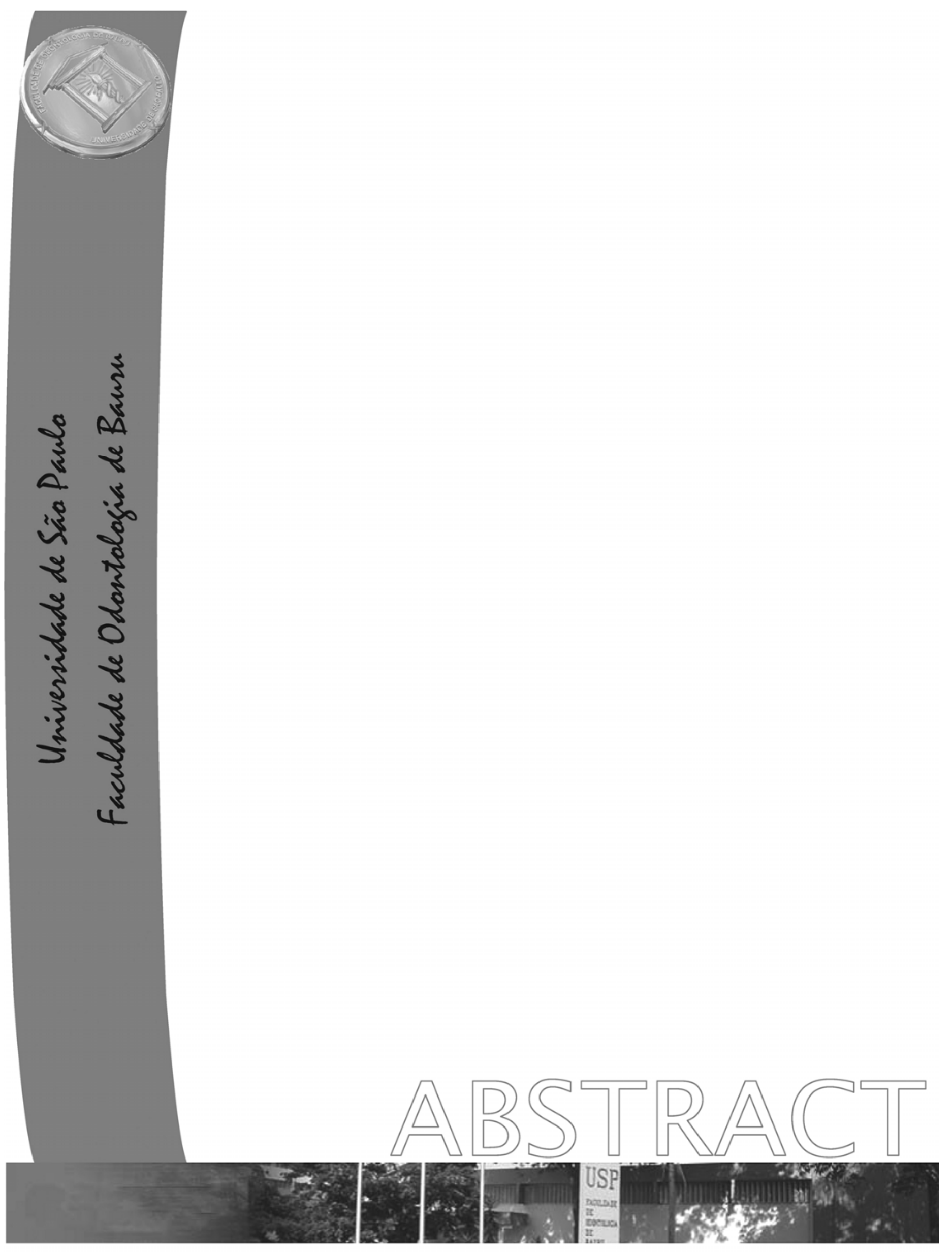




\section{ABSTRACT}

\section{Clinical and radiographic study on 1:5 dilution of Buckley's formocresol, calcium hydroxide and calcium hydroxide preceded by an anti-inflammatory medicine used for pulpotomias of human primary teeth}

The aim of this study was to compare the clinical and radiographic effectiveness of formocresol, calcium hydroxide and calcium hydroxide preceded by an anti-inflammatory medicine: Otosporin ${ }^{\circledR}$ as pulp dressing agents in carious primary teeth. Forty-five primary mandibular molars of 35 children between 5 and 9 years old were carefully selected. The teeth were randomly assigned to formocresol, calcium hydroxide or calcium hydroxide proceeded of anti-inflammatory medicine groups, and treated by a conventional pulpotomy technique in a single session. After coronal pulp removal and hemostasia, in formocresol group, a cotton pellet, soaked in the solution, was placed for 5 minutes over the pulp stumps and the chamber was filled with zinc oxide-eugenol paste. For the group of calcium hydroxide, the powder was accommodated over the pulp stumps with the aid of a sterile door amalgamation. In the third group a cotton pellet, soaked in Otosporin ${ }^{\circledR}$ was placed for 5 minutes over the pulp stumps and then the calcium hydroxide powder was accommodated over the pulp stumps with the aid of a sterile door amalgamation. All the teeth were restored with reinforced zinc oxide-eugenol base and resin modified glass ionomer cement $\left(\right.$ Vitremer $\left.{ }^{\circledR}\right)$. Clinical and radiographic evaluations were recorded at 3, 6 and 12-month follow-up. Only 43 of 45 teeth were available for 3 and 6 month follow-up due to withdrawal of 2 children. But at 6 month follow-up 2 teeth of the calcium hydroxide group need to be extracted because clinical failure. At 12 month follow-up, 7 teeth could not be assessed (3 teeth naturally exfoliate and 4 teeth need to be extracted because clinical failure). No sign of clinical or radiographic failure was observed in the formocresol group in all periods. The other groups of the study revealed internal resorption already at 3 month follow-up, as well as the presence of dentin barrier was also observed that time already, and calcium hydroxide group was the only one to show clinical failure. The use of an anti-inflammatory medicine seems to help a larger index of clinical success when the use of calcium hydroxide for pulpotomies in primary teeth, because this seems to be a extremely sensitive technique.

Keywords: Pulpotomy. Primary teeth. Fomorcresol. Calcium hydroxide. Anti-inflammatory medicine. 


\section{LISTA DE ILUISTRAÇÕES}

- QUADROS

Quadro 1 - Distribuição dos dentes e idade dos pacientes no momento da realização das pulpotomias.

\section{- FIGURAS}

Figura 1 - Fluxograma com a seqüência de procedimentos clínicos realizados.

Figura 2 - Fluxograma dos pacientes e dentes pulpotomizados até 12 meses..

Figura 3 - Pulpotomia do dente 84 com Formocresol (sucesso radiográfico)......

Figura 4- Pulpotomia do dente 75 com Formocresol (sucesso radiográfico)

Figura 5 - Pulpotomia do dente 74 com Hidróxido de cálcio (sucesso radiográfico).

Figura 6 - Pulpotomia do dente 84 com Hidróxido de cálcio (insucesso radiográfico) e pulpotomia do dente 85 com Formocresol (sucesso radiográfico).

Figura 7 - Pulpotomia do dente 74 com Hidróxido de cálcio precedido de antiinflamatório - Otosporin ${ }^{\circledR}$ (sucesso radiográfico)......

Figura 8 - Pulpotomia do dente 84 com Hidróxido de cálcio precedido de antiinflamatório - Otosporin ${ }^{\circledR}$ (insucesso radiográfico) 


\section{LISTA DE TABELAS}

Tabela 1 - Porcentagem de sucesso (S) e falha (F), observados clínica e radiograficamente para os grupos Formocresol, Hidróxido de cálcio e Hidróxido de cálcio precedido de antiinflamatório (Otosporin $^{\circledR}$ ), aos 3, 6 e 12 meses.

Tabela 2 - $\quad$ Média geral de sucesso e insucesso dos medicamentos...................

Tabela 3 - Reabsorção interna observada radiograficamente para pulpotomias com Formocresol, Hidróxido de cálcio e Hidróxido de cálcio precedido de antiinflamatório (Otosporin ${ }^{\circledR}$ ), aos 3, 6 e 12 meses de acompanhamento.

Tabela 4 - Lesão de furca observada radiograficamente para pulpotomias com Formocresol, Hidróxido de cálcio e Hidróxido de cálcio precedido de antiinflamatório (Otosporin ${ }^{\circledR}$ ), aos 3, 6 e 12 meses de acompanhamento.

Tabela 5 - Mobilidade observada clinicamente para pulpotomias com Formocresol, Hidróxido de cálcio e Hidróxido de cálcio precedido de antiinflamatório (Otosporin ${ }^{\circledR}$ ), aos 3, 6 e 12 meses de acompanhamento.

Tabela 6 - Fistula/abscesso observados clinicamente para pulpotomias com Formocresol, Hidróxido de cálcio e Hidróxido de cálcio precedido de antiinflamatório (Otosporin ${ }^{\circledR}$ ), aos 3, 6 e 12 meses de acompanhamento.

Tabela 7 - Barreira dentinária observada radiograficamente para pulpotomias com Formocresol, Hidróxido de cálcio e Hidróxido de cálcio precedido de antiinflamatório (Otosporin ${ }^{\circledR}$ ), aos 3, 6 e 12 meses de acompanhamento. 


\section{LISTA DE ABREVIATTURAS E SIGLATS}

\begin{tabular}{|c|c|}
\hline$\%$ & Porcentagem \\
\hline${ }^{0} \mathrm{C}$ & Graus Celsius \\
\hline $\mathbf{c m}$ & Centímetros \\
\hline CIV & Cimento de Ionômero de Vidro \\
\hline CIVmr & Cimento de Ionômero de Vidro modificado por resina \\
\hline FC & Formocresol \\
\hline HC & Hidróxido de cálcio \\
\hline $\mathrm{Ca}(\mathrm{OH})_{2}$ & Hidróxido de cálcio \\
\hline $\mathbf{H}$ & Hora \\
\hline in vitro & Em Laboratório \\
\hline in vivo & No Ser Humano \\
\hline IRM & Material Restaurados Intermediário \\
\hline MTA & Agregado Trióxido Mineral \\
\hline mm & Milímetro \\
\hline ml & Mililitro \\
\hline $\mathrm{n}^{\mathbf{0}}$ & Número \\
\hline OZE & Óxido de Zinco e Eugenol \\
\hline ph & Potencial Hidrogênico \\
\hline $\mathbf{p}$ & Nível de Significância \\
\hline $\mathbf{R X}$ & Raios - X \\
\hline SF & Sulfato Férrico \\
\hline$\mu \mathrm{m}$ & Micrometro \\
\hline$\mu g$ & Micrograma \\
\hline${ }^{14} \mathrm{C}$ & Isótopo Radioativo do Elemento Carbono \\
\hline${ }^{14} \mathrm{CO}_{2}$ & Isótopo Radioativo do Gás Carbônico \\
\hline
\end{tabular}




\section{SUMAরRRIO}

1 Introdução

2 Revisão de Literatura

2.1 Formocresol

2.2 Hidróxido de cálcio

2.3 Antiinflamatório

3 Proposição

3. 1 Hipóteses

4 Material e Métodos

4.1 Comitê de ética

4.2 Seleção da amostra e determinação dos grupos

4.3 Procedimentos clínicos

80

4.4 Análise clínica e radiográfica aos 3, 6 e 12 meses

82

4.5 Análise estatística

5 Resultados

6 Discussão

7 Conclusão

Referências

Anexos 


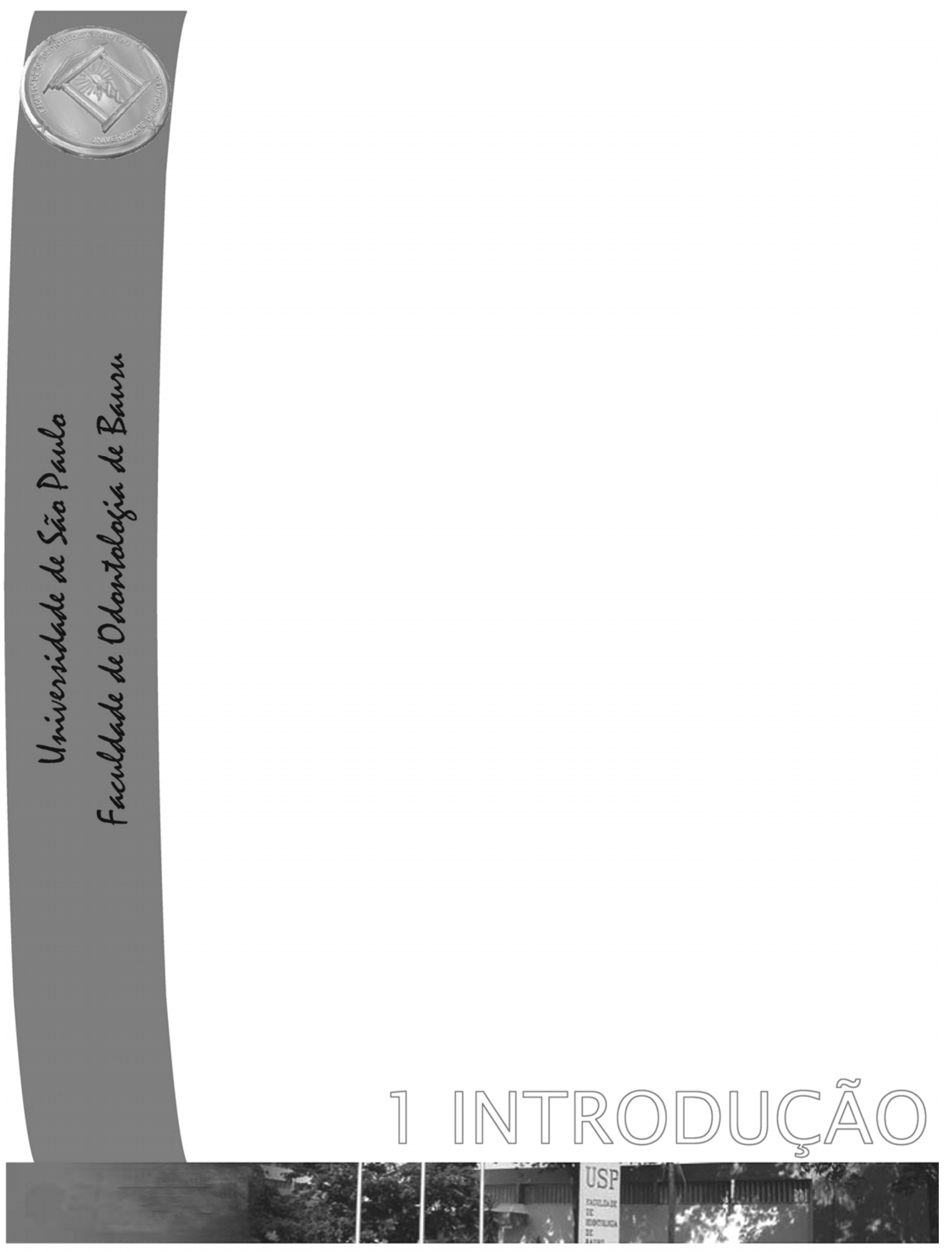




\section{INTRODUÇत̃ก}

Os atuais progressos nas filosofias de prevenção e o conhecimento cada vez mais amplo sobre a etiologia da cárie dentária, somado a um melhor controle sobre os fatores relacionados ao seu aparecimento, traz uma nova proposta de trabalho que envolve não só o diagnóstico precoce como também a realização de tratamentos menos invasivos.

A aplicação destes princípios na clínica odontopediatrica ganha destaque, pois a manutenção da dentição natural na cavidade bucal, sem perdas prematuras, auxiliam na manutenção do comprimento do arco, na prevenção de hábitos deletérios e na preservação do equilíbrio estético-muscular (ABDO et al. 1981; PASTOR 1986; CASTRO 2005), e a perda precoce desses dentes tem uma forte repercussão no crescimento e desenvolvimento esquelético e dentário, trazendo desordens fonéticas e maloclusões (FUCKS 2000).

Para situações clínicas que envolvam direta ou indiretamente o órgão pulpar, é importante primeiramente tentar evitar o tratamento endodôntico convencional, sendo assim dispõe-se da pulpotomia em dentes decíduos, que é uma técnica conservadora de terapia pulpar, amplamente utilizada em Odontopediatria (ARAÚJO et al. 2004).

Esta técnica é bastante indicada, pois consiste da amputação da porção coronária e proteção do remanescente radicular com um material que seja capaz de mantê-lo biologicamente saudável, totalmente envolvido por uma camada odontoblástica e ao mesmo tempo induzir à formação de uma ponte de dentina contínua e espessa, preservando saudável e vital a polpa radicular, o que evita a perda prematura dos dentes (KRAMER; FARACO JÚNIOR; FELDENS 2000; STRANGE et al. 2000; CASTRO 2005) e a aceleração da rizólize (HUNTER 2003; ESTRELA 2004).

Apesar de ser uma técnica estudada há muitos anos, e rotineiramente utilizada em Odontopediatria, ainda hoje causa muitas controvérsias e discussões com relação à falta de medicamentos eficazes e a biocompatibilidade destes, além das dificuldades e falhas no correto diagnóstico da condição pulpar, que é de fundamental importância para o sucesso do tratamento. Sinais clínicos como sangramento de coloração normal, consistência do tecido pulpar ao corte e facilidade de hemostasia sugerem condições favoráveis do tecido (FUCKS 2000; ROCHA et al. 2000; EIDELMAN; HOLAN; FUCKS 2001; BERNABÉ; HOLLAND 2004).

Mesmo com o avanço da ciência e o estudo de novos materiais, não existe ainda hoje um material ideal para procedimentos conservadores da vitalidade do órgão pulpar remanescente. Segundo Pereira (2004) tal material deveria apresentar os seguintes requisitos: 
ser biologicamente compatível com o complexo dentino pulpar; estimular a recuperação das funções biológicas da polpa, culminando com a formação de barreira de tecido mineralizado; possuir propriedades bactericidas e bacteriostáticas; vedar as margens cavitárias; ser adesivo às estruturas dentárias; apresentar boa resistência mecânica para suportar a mastigação; ser bom isolante térmico e elétrico; ser insolúvel no meio bucal. Porém os inúmeros materiais disponíveis hoje no mercado e utilizados em pulpotomias de dentes decíduos não preenchem esses requisitos, o que gera muita discussão sobre a escolha de um medicamento ideal. E conseqüentemente muito se pesquisa sobre medicamentos para a pulpotomia em dentes decíduos, visando conhecer o mecanismo de ação das drogas, sua indicação para uso clínico, bem como as vantagens e desvantagens dos mesmos (GIRO et al. 1991; NADIN et al. 2003; PEREIRA 2004).

Nos últimos 60 anos, o formocresol tem sido o medicamento de escolha para a realização de pulpotomias de dentes decíduos (FUCKS et al. 1997a). Seu uso foi preconizado por Buckley em 1904. E em 1975 Morawa propôs a utilização da fórmula original diluída a $1 / 5$, o que atualmente tem sido preferido por demonstrar a mesma efetividade, porém com menos efeitos tóxicos (ABDO 1976; ABDO et al. 1981; BENGSTON; GUEDES-PINTO; BENGSTON 1986; VONO et al. 1991; BURNETT; WALKER 2002; RIVIERA et al. 2003).

$\mathrm{O}$ alto índice de sucesso clínico e radiográfico em pulpotomias em dentes decíduos utilizando o formocresol já foi demonstrado em vários estudos até hoje (VONO et al. 1991; PUPPIN-ROTANI; POSSOBON; KASSAWARA 1999; WATERHOUSE; NUNN; WHITWORTH 2000; STRAGE et al. 2001; DEAN et al. 2002). Entretanto, atualmente muito se questiona com relação à absorção sistêmica, a citotoxicidade e ao potencial carcinogênico e mutagênico do formocresol (MYERS et al. 1978; PASHLEY et al. 1980; RANLY 1985; ZARZAR 2003; CASAS et al. 2005; SRINIVASAN; PATCHETT; WATERHOUSE 2006; FORNETTI 2007; MORETTI 2008). Pois, a Agência Internacional de Pesquisa do Câncer (International Agency of Research on Câncer - IARC) classificou, em junho de 2004, o formaldeído (um dos componentes do formocresol de Buckley) como substância carcinogênica, com suficientes evidências de desenvolvimento de câncer nasofaríngeo em humanos (SRINIVASAN; PATCHETT; WATERHOUSE 2006).

$\mathrm{Na}$ luz dos fatos, um número crescente de pesquisas por substâncias mais biocompatíveis, alternativas ao formocresol para o uso nos tratamentos pulpares de dentes decíduos, dentre eles o hidróxido de cálcio (MASSARA 1996; WATERHOUSE; NUNN; WHITWORTH 2000a) o glutaraldeído (GIRO et al. 1991; SHUMAYRIKH; ADENUBI 1999) o sulfato férrico (FUCKS et al. 1997a; FUCKS et al. 1997b; BURNETT; WALKER 
2002) e, mais recentemente o agregado trióxido mineral ou MTA (ROCHA et al. 2000; CUISIA et al. 2001; EIDELMAN; HOLAN; FUCKS 2001; AGAMY et al. 2004; MAROTO et al. 2005; AEINEHCHI et al. 2007, MORETTI et al.) e as proteínas morfogenéticas ou BMPs (SOVIERO; SOUZA; GAMA 1991).

O hidróxido de cálcio é um material já bastante utilizado em terapias pulpares de dentes permanentes, e agora vem ganhando espaço nas terapias de dentes decíduos. Em Odontologia esse material, que se apresenta como um sal cristalino, branco e suavemente solúvel, ganhou bastante campo devido suas propriedades antimicrobianas e pela capacidade de induzir a formação de tecido duro (WITHERSPOON et al. 2006). As propriedades mineralizadoras e antimicrobianas do hidróxido de cálcio são explicadas pela ação dos íons provenientes da dissociação iônica do hidróxido de cálcio em íons cálcio $\left(\mathrm{Ca}^{+2}\right)$ e hidroxila $\left(\mathrm{OH}^{-}\right)$(LAW 1956; FOREMAN e BARNES 1990; WATERHOUSE; NUNN; WHITWORTH 2000).

Além dos materiais a serem utilizados para o capeamento do remanescente pulpar após a pulpotomia, quando está é realizada em dentes permanentes, preconiza-se a utilização de medicamentos que estimulem o potencial de defesa do organismo, e esta técnica constitui uma alternativa viável e perfeitamente indicada para dentes decíduos. A literatura reporta que um curativo com a utilização de uma associação de corticóide-antibiótico auxilia no processo de reparação da polpa, atenuando a intensidade da reação inflamatória provocada devido à evolução da lesão de cárie e também pelo ato cirúrgico, reduzindo o aumento da pressão pulpar interna, o que poderia vir a prejudicar o reparo da polpa remanescente, pois existe uma relação entre a intensidade da reação inflamatória e o resultado do tratamento (ESTRELA, 2004).

Certamente, a busca por novas alternativas para o tratamento pulpar é uma constante nos dias de hoje, pois ainda existem muitas duvidas quanto ao material biologicamente mais indicado e modificações na técnica a ser utilizado em pulpotomias de dentes decíduos. Sendo assim, visando dar continuidade a esse campo de pesquisa das diferentes terapêuticas para manter a vitalidade da polpa radicular e, conseqüentemente, o ciclo biológico do dente decíduo, é que esta pesquisa foi desenvolvida, comparando técnicas já comprovadas na literatura, com medicamentos eficazes na terapêutica de dentes permanentes e promissores para a técnica de pulpotomia em dentes decíduos. 


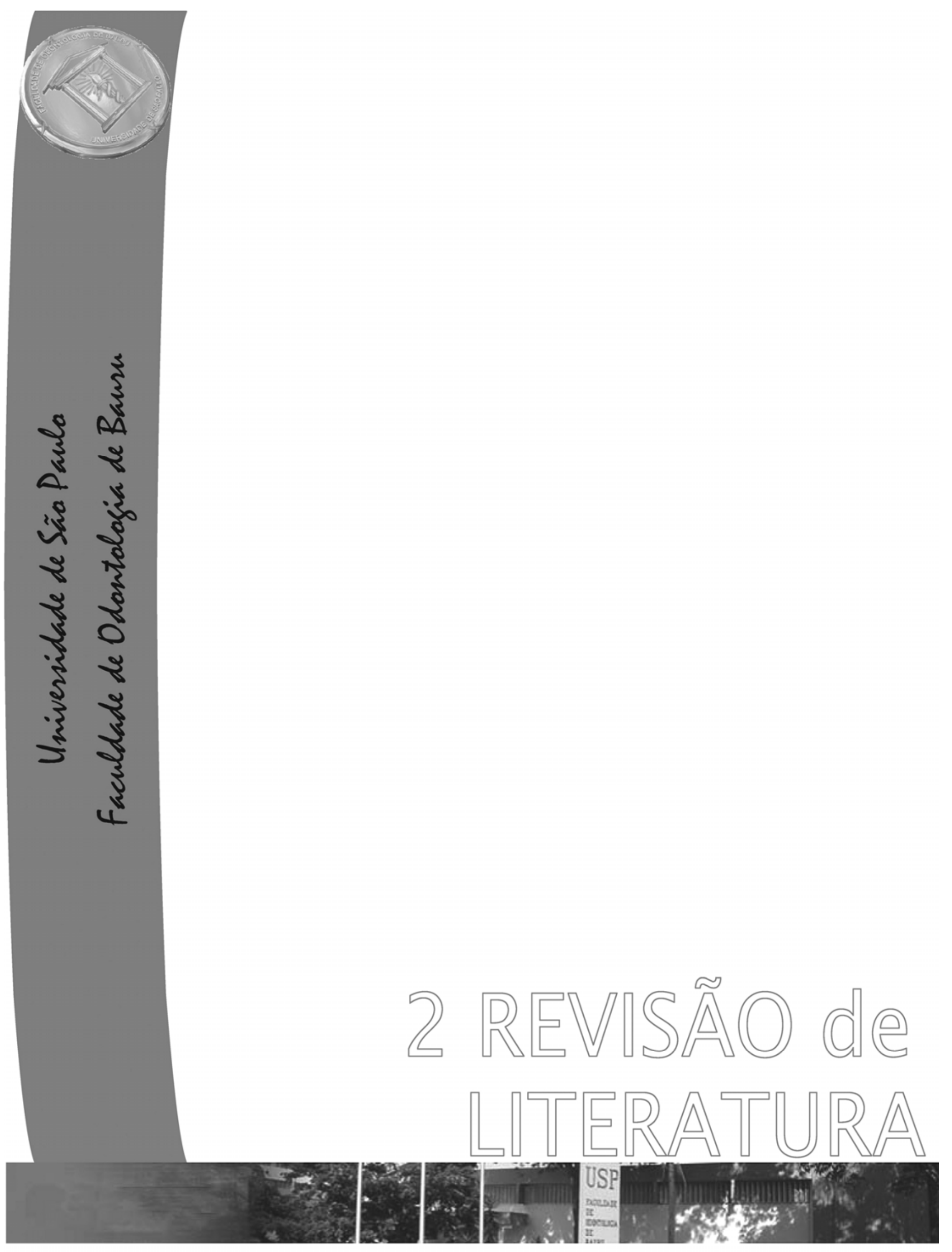




\section{REVISন̃̄O DE LITERATURA}

\subsection{Formocresol}

O formocresol foi introduzido como medicamento odontológico por Buckley em 1904, e só proposto para o uso em dentes decíduos em 1930 por Sweet. Em 1975 Morawa propôs o uso da fórmula original diluída a 1/5 e a partir daí vários estudos tem sido realizado comparando-se as duas fórmulas. Atualmente há uma grande preocupação por parte dos pesquisadores, com relação ao potencial citotóxico, mutagênico e carcinogênico do formocresol, observado em estudos com animais (WATHERHOUSE, 1995).

ABDO, em 1976, comparou os efeitos das duas fórmulas, o formocresol original de Buckley e a versão diluída a 1/5, sobre a polpa e os tecidos periapicais de dentes decíduos de cães. Para tanto 36 molares de cães foram empregados, sendo que 16 dentes do hemiarco direito foram pulpotomisados e tratados com formocresol em sua versão diluída. Nos 16 molares do lado oposto foi utilizada a fórmula original de Buckley. Os animais foram divididos em dois grupos, um primeiro sacrificado aos 15 dias de pós-operatório e o segundo aos 30 dias do pós-operatório, em seguida foram preparadas as peças para análise histológica. A partir da avaliação dos resultados concluiu-se que ambas as fórmulas provocam alterações pulpares destrutivas e irreversíveis, bem como alterações inflamatórias nos tecidos periapicais de dentes decíduos de cães, incluindo os folículos dentários. A fórmula diluída a 1/5 mostrou danos e alterações mais atenuados do que a fórmula original de Buckley.

PRUHS; OLEN; SHARMA, em 1977, avaliaram clínica e radiograficamente a relação existente entre pulpotomias de dentes decíduos realizadas com formocresol de Buckley e a ocorrência de defeitos no esmalte dos dentes permanentes sucessores. Vinte e cinco pré-molares foram avaliados sendo que os defeitos de esmalte foram definidos como qualquer anormalidade na morfologia ou na coloração da coroa. Foram considerados para o grupo controle os vinte e cinco pré-molares antagonistas aos lados tratados. Os resultados indicaram positiva a relação entre pulpotomias de dentes decíduos com formocresol e defeitos de esmalte em seus permanentes sucessores. Para os autores, esta informação deveria ser considerada antes da decisão de se utilizar formocresol em pulpotomias de dentes decíduos. 
MYERS et al., em 1978, investigaram se ocorre a captação de ${ }^{14} \mathrm{C}$-formaldeído pela circulação sistêmica após uma pulpotomia utilizando formocresol como medicamento. Utilizou-se formocresol contendo ${ }^{14} \mathrm{C}$-formaldeído como medicamento para as pulpotomias, realizadas em molares decíduos e permanentes de 5 macacos resus. Foi observada a taxa de ${ }^{14} \mathrm{C}$-formaldeído no plasma e na urina por um período de 2 horas. Decorridos 5 minutos da exposição do tecido pulpar ao ${ }^{14} \mathrm{C}$-formaldeído observou-se uma absorção sistêmica de aproximadamente $1 \%$ da dose aplicada no dente, porém após o período de 2 horas não houve nenhum aumento dessa absorção. Porém quando realizadas pulpotomias múltiplas e seqüências em um mesmo animal havia uma alta absorção sistêmica do ${ }^{14} \mathrm{C}$-formaldeído. Tecidos pulpares previamente tratados com formocresol apresentaram uma absorção moderada de ${ }^{131}$ I quando aplicado sobre eles, enquanto que tecidos não tratados apresentam uma absorção maior, o que indica que o formocresol compromete a microcirculação da polpa dentária. Uma grande concentração do ${ }^{14} \mathrm{C}$-formaldeído pode ser observada no ligamento periodontal, osso, dentina e polpa após a análise da auto-radiografia. E a análise da urina mostrou uma excreção substancial do ${ }^{14} \mathrm{C}$-formaldeído, o que indica que o mesmo foi filtrado pelos glomérulos e sem permanecer ligado às proteínas em sua totalidade. Diante desta absorção sistêmica que ocorre após a aplicação de medicamentos sobre a polpa vital, os autores enfatizam uma escolha criteriosa das substâncias.

PASHLEY et al., em 1980, se propuseram a determinar a distribuição sistêmica do ${ }^{14} \mathrm{C}$-formaldeído a partir dos locais de pulpotomia. Os resultados demonstraram que esta droga é absorvida sistemicamente e aparece na circulação. Uma parte do ${ }^{14} \mathrm{C}$-formaldeído é metabolizada em ${ }^{14} \mathrm{CO}_{2}$ embora isso represente uma fração muito pequena do total da dose absorvida sistemicamente. Outra parte foi encontrada em maior quantidade no fígado e em menor proporção nos músculos. Uma alta quantidade de ${ }^{14} \mathrm{C}$ na bile está correlacionada com os altos valores tecido-plasma no fígado e demonstram a concentração de formaldeído pelo sistema biliar. Os valores tecido-plasma relativamente altos nos rins também se correlacionaram com a limpeza renal do ${ }^{14} \mathrm{C}$ que indica uma reabsorção do formaldeído filtrado. Estes resultados demonstram que o formocresol é absorvido e distribuído rápida e amplamente pelo corpo em poucos minutos após ser colocado no local da pulpotomia.

RANLY, em 1985, testou a distribuição sistêmica e a toxicidade do formaldeído após pulpotomias em ratos, bem como após a injeção do ${ }^{14} \mathrm{C}$-formaldeído na veia jugular destes animais, pois os efeitos mutagênicos e carcinogênicos do formaldeído, principal constituinte 
do formocresol, eram questionáveis. A comparação entre as doses, tanto a aplicada sobre a polpa quanto a injetada na veia jugular sugere que aproximadamente que $30 \%$ do formaldeído pipetado na câmara pulpar foram distribuídos sistemicamente em 5 minutos. Estes resultados foram derivados da comparação dos valores do plasma, fígado e rins. Os pulmões e músculos do grupo que recebeu a injeção na veia jugular apresentou porcentagens mais baixas, sugerindo que a administração venosa do formaldeído permite um metabolismo mais rápido e expiração do ${ }^{14} \mathrm{CO}_{2}$.

BENGTSON, GUEDES-PINTO E BENGTSON, em 1986, realizaram um estudo no qual avaliaram, clínica e radiograficamente, oitenta e quatro dentes decíduos cariados submetidos à pulpotomia com formocresol de Buckley diluído a 1/5. As avaliações se deram em períodos de 3 a 8 meses, 9 a 12 meses e 13 a 18 meses. Os resultados mostraram sucesso de 95\% no período de 3 a 8 meses, 93\% de 9 a 12 meses e 100\% de 13 a 18 meses. Na soma de todos os dentes em todos os tempos, o resultado evidenciou apenas três falhas, portanto, 96,4\% de sucesso na avaliação total. Diante destes dados os autores afirmaram ser viável o uso do formocresol diluído a 1/5 em pulpotomias de molares decíduos.

Com o objetivo de estudar a ação do ácido sulfossalicílico-cresol (ácido sulfossalicílico 50\% em glicerol e cresol 35\%) e do formocresol (formol 19\%, cresol 35\% e água glicerinada q.s.p. 100\%), nos tecidos pulpar e periapical de dentes decíduos de cão, ARAÚJO et al., em 1987, realizaram um experimento com 40 molares decíduos de cães com idades variando entre 70 e 90 dias. Vinte molares do hemiarco inferior esquerdo foram submetidos à pulpotomia e tratamento da polpa remanescente com formocresol (aplicação com bolinha de algodão sobre os cotos pulpares por cinco minutos). Nos molares do lado oposto foi empregada a solução do ácido sulfossalicílico-cresol obedecendo ao mesmo critério da técnica. Os animais foram sacrificados aos 7, 15 e 30 dias do pós-operatório e as peças preparadas para estudo histológico. A análise dos resultados permitiu observar que o ácido sulfossalicílico-cresol, na concentração utilizada, provocou alterações pulpares caracterizadas por necrose de coagulação, inflamação e reabsorção dentinária interna. As alterações foram semelhantes às provocadas pelo formocresol na fórmula original da Buckley. Ainda, tanto o ácido sulfossalicílico-cresol quanto o formocresol de Buckley não determinaram alterações nos tecidos periapicais e folículos dentários do dente permanente sucessor. 
MULDER, AMEROGEN VAN E VINGERLING, em 1987, compararam clínica e radiograficamente 278 pré-molares divididos igualmente em grupo teste (tratados com formocresol) e grupo controle (dentes contralaterais), visando estudar o desenvolvimento de lesões de esmalte em dentes permanentes sucessores de dentes decíduos tratados por pulpotomias com formocresol. Estes dentes foram analisados por dois examinadores que avaliaram as lesões do esmalte em opacidade e hipoplasia. Não existiu diferença significante no número de dentes com lesão em esmalte entre no grupo teste e o grupo controle. Comparações separadas de opacidade e hipoplasia também não mostraram diferença significante, mesmo quando relatada a idade da criança no momento em que a pulpotomia foi realizada. A pulpotomia com formocresol não exerceu nenhuma influência no tamanho das lesões de esmalte encontradas nos dentes permanentes sucessores. As conclusões gerais frente aos resultados evidenciaram que a pulpotomia de dentes decíduos com formocresol pode ser considerada satisfatória, sem relação existente entre o emprego deste medicamento e defeitos de esmalte nos dentes permanentes sucessores.

ALACAM, em 1989, comparou clinica, radiográfica e histologicamente os efeitos do formocresol, do glutaraldeído com hidróxido de cálcio e do glutaraldeído com óxido de zinco e eugenol quando utilizados em pulpotomias de dentes decíduos. Setenta e um molares decíduos foram submetidos à pulpotomias e divididos em três grupos: GI- aplicação de glutaraldeído a $2 \%$ por 5 minutos + pasta de glutaraldeído-óxido de zinco e eugenol; GIIaplicação de glutaraldeído a 2\% por 5 minutos + pasta de glutaraldeído-hidróxido de cálcio; GIII- aplicação de formocresol por 5 minutos + pasta de formocresol-óxido de zinco e eugenol. Todos os grupos receberam uma camada de OZE (presa rápida) e foram devidamente restaurados. As avaliações foram realizadas em um período de 12 meses. Os resultados demonstraram um sucesso clínico e radiográfico, respectivamente, de 96\% e 92\% para GI; de $90,4 \%$ e $76,1 \%$ para GII e de $91,3 \%$ e $82,6 \%$ para GIII. Ainda, a análise histológica também mostrou melhores resultados no GI. Sendo assim, este estudo evidenciou que a combinação de glutaraldeído-óxido de zinco e eugenol pode apresentar vantagens sobre o glutaraldeído-hidróxido de cálcio e o formocresol quando empregados em pulpotomias de dentes decíduos, embora o autor não tenha descartado a necessidade de mais estudos para que esta recomendação possa ser feita.

VONO et al., em 1991, avaliaram clínica e radiograficamente pulpotomias realizadas em molares decíduos bem como a relação desses tratamentos com defeitos estruturais de 
esmalte em seus dentes permanentes sucessores. A amostra constituiu de 61 crianças que nas idades entre 3 e 8 anos tiveram 93 molares decíduos tratados com a técnica convencional de pulpotomia usando formocresol diluído a 1/5. O período de observação variou de 24 a 54 meses. Os resultados demonstraram que dos 35 dentes examinados, 32 molares decíduos com restauração satisfatória apresentaram sucesso clínico de 100\% e radiográfico de 85,72\%. Dos 52 pré-molares sucessores, 17,31\% apresentaram leve alteração de esmalte. Os autores relataram o sucesso clínico e radiográfico do formocresol quando empregado em pulpotomias de dentes decíduos além de não associarem seu uso com defeitos estruturais de esmalte em dentes permanentes sucessores.

Na revisão de literatura realizada por KETLEY E GOODMAN, em 1991, levou-se em consideração a toxicidade do formocresol e algumas evidências sobre a utilização do hidróxido de cálcio e do glutaraldeído em pulpotomias de molares decíduos vitais. Os autores concluíram que mais trabalhos deveriam ser realizados antes da indicação definitiva de substitutos para o formocresol, entretanto, sugerem que neste meio tempo, o formocresol diluído a 1/5 da solução original deveria ser empregado, porém sem ser incluído na pasta subbase de cimento de óxido de zinco e eugenol.

PEREIRA, em 1993, avaliou microscopicamente os efeitos do glutaraldeído a 2\% e do formocresol diluído a $1 / 5$, buscando por melhores medicamentos a serem utilizados como agentes capeadores pulpares em pulpotomias de dentes decíduos. Noventa e seis molares de ratos foram divididos em 4 grupos e após serem submetidos ao procedimento de pulpotomia com remoção da polpa coronária e hemostasia, tiveram seus remanescentes pulpares tratados pela seguintes técnicas: G I - pasta de óxido de zinco e eugenol + glutaraldeído a $2 \%$ após curativo prévio de glutaraldeído a 2\% por 5 minutos; G II - pasta de óxido de zinco e eugenol após curativo prévio de glutaraldeído a $2 \%$ por 5 minutos; G III - pasta de óxido de zinco e eugenol + formocresol a 1/5 após curativo prévio de formocresol a 1/5/ por 5 minutos; G IV pasta de óxido de zinco e eugenol após curativo com formocresol a 1/5 por 5 minutos. Após os períodos experimentais de 7, 15 e 30 dias, os animais foram sacrificados e as peças preparadas para análise histológica. Todos os materiais provocaram respostas inflamatórias degenerativas e/ou involutivas, porém com intensidades variáveis. A região periapical apresentou aspectos de normalidade, em todos os períodos observados, apenas nos grupos tratados com glutaraldeído. A presença de hiperemia com infiltrado inflamatório na região periapical foi mais discreta quando o formocresol não foi incorporado à sub-base. Após estas 
verificações, o autor concluiu que com relação à ação dos medicamentos, as técnicas empregadas nos grupo I e IV apresentaram menor agressividade tecidual.

FUKS et al., em 1997a, compararam os efeitos do sulfato férrico a 15,5\% (SF) e do formocresol diluído a 1/5(FCD), quando utilizados como agentes capeadores pulpares em pulpotomias de molares decíduos. Noventa e seis molares decíduos, de setenta e duas crianças foram tratados pela técnica convencional de pulpotomia. Em cinqüenta e oito dentes, o sulfato férrico foi aplicado por 15 segundos, lavado e uma pasta de óxido de zinco e eugenol (OZE) colocada como base. Em outros trinta e oito dentes, o formocresol foi aplicado por 5 minutos, removido e uma base de OZE acomodada na câmara pulpar. Os dentes de ambos os grupos receberam uma segunda camada de um material restaurador intermediário (IRM) e foram restaurados com coroa de aço. Avaliações clínicas e radiográficas foram realizadas em um período de 6 a 34 meses. Quatro dentes foram excluídos do estudo devido ao não comparecimento dos pacientes nas avaliações. Taxas de sucesso de 92,7\% para o SF e de 83.8\% para o FCD não foram significantemente diferentes. Quatro dentes $(7,2 \%)$ no grupo SF e dois (5,4\%) no grupo FCD apresentaram reabsorção interna. Radiolucência interradicular foi observada em dois dentes no grupo SF e três no FCD, que posteriormente também apresentaram lesões periapicais. O índice de sucesso de ambos os grupos mostrou similaridade com estudos prévios que utilizaram o formocresol de Buckley tradicional.

Com o objetivo de avaliar o efeito do formocresol diluído a $1 / 5$, do sulfato férrico e do IRM $^{\circledR}$ em pulpotomias de dentes decíduos de macacos, FUCKS et al., em 1997b, utilizaram 79 dentes decíduos de 4 macacos com idade entre 1,5 a 2 anos. Os dentes foram divididos em três grupos: 32 receberam pulpotomia com formocresol, 32 dentes com sulfato férrico e 15 dentes com IRM ${ }^{\circledR}$, e todos os dentes da pesquisa foram restaurados com IRM ${ }^{\circledR}$. Decorridos 4 e 8 semanas de pós-operatório os animais foram sacrificados e as peças preparadas para análise histológica. Os resultados mostraram que 60\% dos dentes tratados com o sulfato férrico apresentaram polpa normal, resultados semelhantes aos dos dentes tratados com formocresol. A presença de barreira dentinária também foi um achado comum para os 3 grupos estudados.

LEWIS, em 1998, realizou uma extensa revisão de literatura sobre a história e o uso do formaldeído em odontologia, para tanto alguns artigos de pesquisadores fora da área odontológica foram incluídos, em especial aqueles que demonstravam a mutagênicidade e a 
carcinogênicidade do formaldeído. O autor não discorda da capacidade antibacteriana do formocresol (medicamento que contém formaldeído), porém enfatiza o seu potencial carcinogênico e mutagênico. Relata ainda que independente desses inconvenientes, muitas universidades no mundo todo ainda preconizam o us desse medicamento em pulpotomias de dentes decíduos. Após pesquisar com químicos e com o presidente de uma indústria fabricante do formocresol, o autor relata não haver uma padronização nas formulações desse medicamento. E finaliza afirmando que o formocresol, na revisão de literatura realizada, apresenta efeito tóxico, mutagênico e carcinogênico, além de efeitos sobre o sistema imune. No final de sua revisão o autor ainda sugere que mais pesquisas devam ser realizadas nesse campo, buscando novos e mais eficientes medicamentos para pulpotomias agora sem os efeitos tóxicos.

Através de uma retrospectiva de 36 meses, PUPPIN-RONTANI, POSSOBON E KASSAWARA, em 1999, avaliaram o sucesso clínico e radiográfico do formocresol quando empregado em pulpotomias de dentes decíduos. Cinqüenta e cinco pulpotomias foram examinadas clínica e radiograficamente quanto à presença ou ausência de alterações patológicas. Quando da ausência do dente decíduo, o permanente sucessor irrompido foi analisado através de exame clínico e comparado com o seu antímero quanto à presença de hipoplasias e/ou giroversões. O sucesso da terapêutica foi considerado na ausência de alterações clínicas e radiográficas nos dentes decíduos e de hipoplasias e/ou giroversões nos permanentes já irrompidos. A terapia empregada apresentou uma taxa de 64,5\% de sucesso em média para a amostra, e a porcentagem mais alta foi encontrada nos primeiros 12 meses do tratamento (80,9). A faixa etária que exibiu melhores resultados estava situada entre 9 e 11 anos de idade (83\%), mostrando uma relação diretamente proporcional com o aumento da faixa etária. Para os autores, o uso do formocresol em pulpotomias deveria ser revisado, principalmente em relação a crianças com idade inferior a 5 anos, nas quais os autores reforçaram o emprego do formocresol diluído a 1/5 ou do hidróxido de cálcio como droga de eleição.

SMITH, SEALE E NUNN, em 2000, coletaram dados clínicos e radiográficos de tabelas de pacientes que receberam pulpotomia com sulfato férrico, em clínicas privadas, no período retrospectivo de 5 anos e compararam com dados publicados com a técnica de pulpotomia formocresol.Os dados foram obtidos de 242 molares decíduos de 171 crianças com tempo de acompanhamento de 4 a 57 meses (média de 19 meses). A taxa de sucesso 
radiográfico para o sulfato férrico foi de 74 a 80\%. A aparência radiográfica de polpa normal diminuiu com o tempo e a resposta pulpar freqüentemente observada foi calcificação metamorfósica (6-33\%) e reabsorção interna (7-18\%). A taxa de sucesso clínico para o sulfato férrico foi de 99\%. No geral, as taxas de sucesso neste estudo foram menores que as relatadas em estudos prévios com sulfato férrico em pulpotomias de dentes decíduos, mas são comparáveis aos resultados relatados para a técnica de pulpotomia com formocresol diluído a $1 / 5$.

IBRICEVIC E AL-JAME, em 2000, compararam o sulfato férrico e o formocresol quando utilizados como agentes pulpares em pulpotomias de molares decíduos. Setenta dentes com cáries extensas, sem sintomatologia clínica e qualquer sinal de reabsorção radicular em crianças com idades entre 3 e 6 anos foram tratados pela técnica convencional de pulpotomia. Uma solução de sulfato férrico a 15,5\% foi aplicada por 15 segundos em 35 dentes enquanto que outros 35 receberam a aplicação de formocresol (solução concentrada de Buckley) por cinco minutos. Ambos os grupos tiveram a câmara pulpar preenchida com óxido de zinco e eugenol e foram restaurados com coroa de aço. As avaliações clínicas foram realizadas a cada três meses enquanto que as análises radiográficas se deram aos 6 e 20 meses após o tratamento. Neste período, os resultados revelaram 100\% de sucesso clínico para ambos os grupos. Radiograficamente o sucesso foi de 97,2\%, também para ambos os grupos, sendo que 2,8\% dos casos apresentaram reabsorção interna. Os autores consideraram o sulfato férrico capaz de produzir os mesmos resultados que o formocresol em pulpotomias de dentes decíduos.

Na tentativa de reduzir a exposição ao formocresol em pulpotomias de dentes decíduos, STRANGE et al., em 2001, investigaram o sucesso de uma técnica na qual o formocresol foi incorporado a pasta sub-base de OZE, porém sem a aplicação prévia do medicamento por cinco minutos sobre o remanescente pulpar. Ainda compararam as taxas de sucesso radiográfico quando a reabsorção interna foi ou não considerada como falha do tratamento. Dados clínicos e radiográficos foram coletados de pacientes com pelo menos 1 molar tratado pela técnica de pulpotomia com formocresol apenas na sub-base, entre os anos de 1985 e 1996. Clinicamente, 99\% dos dentes tratados apresentaram sucesso sendo que apenas 2 dentes foram extraídos devido a combinação de sintomatologia clínica e alterações radiográficas patológicas. Através da análise radiográfica tradicional, o índice de sucesso foi de $79 \%$, contra $99 \%$ de sucesso pela análise alternativa na qual a reabsorção interna foi 
excluída como falha. Diante dos resultados encontrados, os autores indicaram que a técnica de pulpotomia com formocresol empregada neste estudo foi satisfatória na terapia pulpar de molares decíduos.

EIDELMAN; HOLAN; FUKS, em 2001, compararam o efeito do MTA e do formocresol quando utilizados como agentes capeadores pulpares em molares decíduos submetidos à pulpotomia após exposição por cárie. Quarenta e cinco molares decíduos de 26 crianças foram tratados pela técnica convencional de pulpotomia e aleatoriamente divididos em 2 grupos: controle com formocresol e experimental com MTA. Após a remoção da polpa coronária e hemostasia, no grupo controle, foi colocado sobre os remanescentes pulpares uma bolinha de algodão com formocresol por 5 minutos; no grupo experimental, sobre os remanescentes pulpares foi acomodado o MTA. Ambos os grupos foram então cobertos com uma pasta de óxido de zinco-eugenol, e restaurados com coroa de aço. Dezoito crianças retornaram para os controles e 32 dentes foram submetidos à avaliação clínica-radiográfica durante 6 a 30 meses. Os resultados das avaliações demonstraram apenas um caso de reabsorção interna no grupo do formocresol, insucesso detectado após 17 meses do procedimento. Nenhum dente do grupo MTA apresentou qualquer patologia clínica ou radiográfica. A obliteração do canal radicular foi observada em 9 dos 32 dentes avaliados, sendo 2 entre os 15 tratados com formocresol (13\%) e 7 entre os 17 tratados com MTA (41\%). Diante dos resultados, os autores concluíram que o MTA mostrou-se um material capeador de sucesso quando utilizado em pulpotomias de molares decíduos, podendo ser considerado um possível substituto para o formocresol.

CUISA et al., em 2001, compararam os efeitos do formocresol e do MTA em pulpotomias de molares decíduos humanos expostos por cárie e que apresentavam vitalidade pulpar. O estudo incluiu 30 pares de molares decíduos de 22 crianças saudáveis com idades entre 2 e 8 anos com pelo menos dois molares necessitando de pulpotomia. Cada criança teve um molar tratado com MTA e o outro com formocresol. Os pacientes foram acompanhados clínica e radiograficamente por 3 e 6 meses do pós-operatório para a comparação de ambos os medicamentos. A avaliação clínica de 3 meses revelou, no grupo do formocresol, 2 dentes com excessiva mobilidade e 1 com abscesso que resultou em extração do elemento do dentário. Para o grupo do MTA, apenas 1 dente apresentou mobilidade e nenhum caso de abscesso foi encontrado. Aos 6 meses, a avaliação clínica não revelou nenhum achado adicional daquela realizada aos 3, para ambos os grupos. Radiograficamente, aos 6 meses 7 
dentes do grupo formocresol e 2 do MTA apresentaram anormalidades consistindo em calcificação degenerativa, espessamento do ligamento periodontal, radiolucência periapical, reabsorção patológica ou envolvimento de furca. Embora o sucesso radiográfico tenha sido de 94\% para o MTA contra 77\% para o formocresol, os achados clínicos e radiográficos de ambos os materiais testados não apresentaram diferenças estatisticamente significantes dentro do período experimental proposto.

Com o objetivo de comparar duas técnicas de pulpotomia, uma com eletrocirurgia e outra utilizando formocresol, DEAN et al., em 2002, realizaram um estudo com 50 crianças, onde cada uma recebeu 1 pulpotomia. Os 50 dentes foram divididos randomicamente em 2 grupos de 25 dentes cada: grupo pulpotomia com eletrocirurgia e grupo pulpotomia com formocresol. Após aproximadamente 5 meses da realização dos tratamentos, os dentes foram avaliados clínica e radiograficamente. As taxas de sucesso clínico e radiográfico para o grupo das pulpotomias com eletrocirurgia foi de $96 \%$ e $84 \%$ respectivamente; e de $100 \%$ e $92 \%$ para o grupo de pulpotomias com formocresol. Os autores relatam que o estudo não pode afirmar qual tratamento foi melhor, já que não houve diferença estatística significante entre os 2 grupos.

HOLAN, FUKS e KELTZ, em 2002, realizaram um estudo retrospectivo com objetivo de comparar a taxa de sucesso de pulpotomias com formocresol em molares decíduos restaurados com coroa de aço ou com amálgama. Trezentos e quarenta e um dentes foram avaliados radiograficamente por um período entre 6 e 103 meses. Foi considerada falha quando os seguintes aspectos radiográficos foram observados: reabsorção radicular interna ou externa; presença de áreas radiolúcidas periapicais ou na região de furca. Obliteração do canal radicular não foi considerada falha. Dos 14\% de casos definidos como "falha” 13\% haviam sido restaurados com coroa de aço e $20 \%$ restaurados com amálgama, sendo que não existiu diferença significante entre os grupos. Das falhas dos dentes restaurados com amálgama, a maioria envolvia mais de uma face dentária. O sinal radiográfico mais observado em todos os dentes com falha foi reabsorção interna. As falhas foram observadas inicialmente após uma média de avaliações de 27 a 29 meses para os dentes restaurados com coroa de aço e amálgama, respectivamente. Obliteração do canal radicular foi detectada em $80 \%$ dos casos , com taxas similares em ambos os grupos. Os autores concluíram que restaurações de amálgama em dentes que receberam pulpotomias podem ser realizadas, desde que envolvam 
apenas 1 face do dente e que esse deva permanecer na cavidade bucal por até 2 anos, até sua esfoliação fisiológica.

Também para avaliar o sucesso clínico e radiográfico de pulpotomias com formocresol em molares decíduos, QUEIROZ et al., em 2002, examinaram pacientes atendidos na clínica de Odontopediatria da Universidade Federal da Paraíba. Dezoito molares decíduos submetidos à pulpotomia com formocresol foram observados no período de 1998 a 2001, em 13 pacientes atendidos por graduandos. O sucesso clínico foi considerado na ausência de mobilidade anormal, alterações gengivais e/ou fístula e na presença de restauração satisfatória. O sucesso da avaliação radiográfica foi considerado na ausência de reabsorção interna e/ou externa, lesão de furca, rarefação óssea difusa e migração do germe dentário permanente. Constatou-se $78 \%$ de sucesso clínico e radiográfico indicando que a realização de pulpotomias com formocresol em molares decíduos pode ser considerada uma técnica aceitável. Em decorrência dos maiores índices de insucesso nos primeiros seis meses após a realização do tratamento, os autores ressaltaram a importância da proservação do elemento dentário após a realização da terapia pulpar.

GUELMANN et al., em 2002, realizaram um estudo retrospectivo avaliando a taxa de sucesso de pulpotomias realizadas no setor de emergência de uma Universidade. Os dados relativos a 216 pulpotomias com formocresol foram obtidos nesse setor, os quais incluíam: intervalo entre a realização da pulpotomia de emergência e a restauração definitiva, tipo de dente, gênero e idade das crianças. Para que os dentes fossem incluídos nesse estudo, esses deveriam ter recebido pulpotomia com formocresol e restauração temporária com óxido de zinco e eugenol reforçado. Num período de 2 anos, 64 dentes foram avaliados. Uma taxa de $53 \%$ de sucesso foi observada quando os dentes foram avaliados e restaurados com restauração definitiva nos primeiros 90 dias após a realização das pulpotomias. Uma taxa de 31\% foi verificada após 365 dias. Os autores concluíram que a baixa taxa de sucesso observada durante os primeiros 3 meses após o tratamento de emergência poderia ser atribuída a uma inflamação pulpar subclínica não diagnosticada. Já as falhas observadas em longo prazo poderiam estar associadas à microinfiltração do material restaurador provisório.

Ao apresentar um caso clínico de esfoliações prematuras de molares decíduos, possivelmente associadas ao uso de formocresol como medicamento em pulpotomias, HUNTER, em 2003, descarta as causas sistêmicas e relaciona o fato à capacidade do 
formocresol em se difundir e atravessar o ápice radicular afetando os tecidos periapicais, principalmente quando grandes quantidades do medicamento são empregadas. Embora este seja um caso isolado, o autor não descartou a possibilidade de que o formocresol tenha sido o agente causador das esfoliações precoces dos molares tratados previamente com a substância.

RITWIK et al., em 2003, comparou os materiais formocresol e MTA como agentes capeadores em pulpotomias de dentes decíduos. Em seu estudo 60 molares decíduos de 22 crianças foram tratados ou com MTA ou com formocresol e os dentes restaurados com coroa de aço. As avaliações clínicas e radiográficas foram realizadas após 6 meses e 3 anos, porém os resultados de 3 anos ainda não foram divulgados. Clinicamente foi avaliado: presença de dor, mobilidade, sensibilidade à percussão e presença de fístula e abscesso. Radiograficamente foi avaliado: degeneração cálcica da polpa, espessamento do ligamento periodontal, radiolucidez periapical e de furca e reabsorção patológica. Os resultados obtidos aos 6 meses foram: 2 dentes do grupo formocresol e 1 dente do grupo MTA apresentaram sinais clínicos de insucesso, enquanto que 7 do grupo formocresol e 2 do grupo MTA apresentaram sinais radiográficos de falha. Os autores não encontraram diferença entre os 2 materiais aos 6 meses de observação. Segundo os autores, os dados de 3 anos deverão ser ainda divulgados.

RIVERA et al., em 2003, avaliaram clínica e radiograficamente 80 molares decíduos de crianças com idades entre 4 e 7 anos, com pelo menos 2 molares decíduos necessitando de terapia pulpar. Foram excluídos os dentes que apresentaram um mais dos sinais e sintomas clínico e/ou radiográfico: mobilidade, sensibilidade à percussão, fistula, drenagem via sulco, reabsorção interna ou apical, odor fétido e comprometimento de furca. Também foram excluídos os pacientes portadores de diabetes, cardiopatias e alterações renais. Após a realização de pulpotomia com formocresol diluído a 1/5 e com eletrocirurgia, foram feitas avaliações no período de 1, 3 e 6 meses do pós-operatório. Os resultados não mostraram nenhuma diferença significante entre as técnicas em todos os períodos estudados. Entretanto, a eletrocirurgia demonstrou ser uma técnica de aplicação mais rápida, além de dispensar o uso do formocresol e, conseqüentemente, os riscos inerentes aos seus efeitos adversos.

ZARZAR et al., em 2003, investigaram a mutagenicidade do formocresol de Buckley, na concentração original, em cultura de linfócitos obtidos do sangue de crianças com idades entre 5 e 10 anos que receberam pulpotomia nos molares decíduos empregando-se esta 
substância. As amostras dos sangues foram coletadas antes da pulpotomia (grupo controle) e 24 horas após o tratamento (grupo teste). Os linfócitos foram analisados quanto a ocorrência de aberrações cromossômicas. A análise citogenética foi realizada em um teste cego. Os resultados não demonstraram diferenças estatisticamente significantes entre os grupos. No entanto, o formocresol de Buckley foi mutagênico para um paciente, levantando dúvidas sobre o seu emprego em pulpotomias de crianças. Diante dos resultados, o formocresol apresentou-se não mutagênico. Contudo, os autores consideraram a importância de mais investigações, principalmente em crianças que necessitem de mais de uma pulpotomia, na intenção de verificar se um aumento na quantidade da droga aumentaria também as aberrações cromossômicas.

Com o objetivo de estudar e comparar clínica radiográfica e histologicamente três diferentes materiais como capeadores pulpares em pulpotomias de dentes decíduos, AGAMY et al., em 2004, selecionaram 24 crianças, cada uma com pelo menos 3 molares decíduos necessitando de pulpotomia, para a parte clínica e radiográfica de seu estudo, e outros 15 dentes decíduos cariados com planejamento de extração seriada foram selecionados para a parte histológica. Os dentes foram divididos em 3 grupos, segundo o material a ser utilizado como capeador, e as pulpotomias realizadas. As avaliações clínica e radiográfica foram realizadas periodicamente por 12 meses (1, 3, 6 e 12 meses). Os dentes tratados para o estudo histológico foram monitorados periodicamente e extraídos 6 meses do pós-operatório. Doze dentes pulpotomizados não puderam ser avaliados devido ao não comparecimento dos pacientes nos retornos. Um dente (MTA cinza) esfoliou normalmente e 6 dentes (4 do MTA branco; 2 do formocresol) falharam devido a presença de abscesso. Dos 53 dentes restantes, todos apresentaram sucesso clínico e radiográfico nos 12 meses de proservação. A obliteração do canal pulpar foi encontrada 11 dentes tratados com MTA cinza 1 tratado com MTA branco. Na análise histológica, ambos os MTAs induziram a formação de barreira dentinária no local da amputação pulpar, enquanto que o formocresol induziu apenas a formação de uma dentina fina e pobremente calcificada. Os dentes tratados com MTA cinza demonstram arquitetura pulpar o mais próxima da polpa normal através da preservação da camada odontoblástica e delicada matriz fibrocelular, e ainda com poucas células inflamatórias. Os dentes tratados com MTA branco mostraram um padrão de fibrose denso, com calcificações isoladas no tecido pulpar ao longo da formação de dentina secundária. Os autores concluíram que o MTA cinza foi superior ao MTA branco e ao formocresol quando empregados em pulpotomias de dentes decíduos. 
JABBARIFAR; KHADEMI; GHASEMI, em 2004, compararam o sucesso clínico e radiográfico do formocresol com o MTA em pulpotomias de molares decíduos humanos. Sessenta e quatro dentes, aleatória e igualmente divididos em 2 grupos, foram pulpotomizados com MTA e com formocresol. A falha no tratamento foi definida quando do aparecimento de um ou mais eventos, tais como reabsorção interna e/ou externa, radiolucência na região de furca e/ou periapical, dor, edema, mobilidade, abscesso e extração prematura do dente tratado. Todos os tratamentos com ausência dos eventos acima citados foram considerados como sucesso. Após 6 e 12 meses do pós-operatório, o índice de sucesso e de falha foi de 93,7\% e 6,3\% para o MTA e de 90,2\% e 8,4\% para o formocresol, respectivamente. Um dente no grupo do MTA e 3 no formocresol apresentaram reabsorção interna. No total, 60 dentes (92,8\%), de ambos os grupos, foram considerados como sucesso, uma vez que nenhum deles apresentou qualquer sinal ou sintoma clínico e/ou radiográfico. As diferenças entre o MTA e o formocresol, no método empregado, não foram estatisticamente significante, sugerindo aos autores que o MTA pode ser uma alternativa ao formocresol no procedimento de pulpotomia em dentes decíduos.

Na busca por substâncias alternativas ao formocresol para utilização como medicamento nos procedimentos de pulpotomia, FARSI et al., em 2005, compararam cínica e radiograficamente o MTA e o formocresol (FC) quando utilizados em pulpotomias de molares decíduos humanos. A amostra foi constituída de 120 molares decíduos, igualmente divididos em 2 grupos (MTA e formocresol), que foram tratados pela mesma técnica convencional de pulpotomia. Após o período de avaliação clínica e radiográfica de 24 meses, 74 molares (36 FC e 38 MTA) foram analisados. Os resultados mostraram que nenhum dente tratado com MTA apresentou alterações clínicas ou radiográficas, evidenciando 100\% de sucesso neste grupo. No grupo do formocresol, foi observado um sucesso clínico e radiográfico de 98,6\% e $86,8 \%$ dos casos, respectivamente. As diferenças entre os dois grupos foram estatisticamente significantes apenas para os resultados radiográficos. Concluiu-se que o MTA pode ser um possível substituto ao formocresol, especialmente em crianças com necessidades de pulpotomias múltiplas em dentes decíduos.

HOLAN, EIDELMAN e FUKS, em 2005, avaliaram o efeito do agregado trióxido mineral (MTA) como agente capeador após pulpotomia em molares decíduos com polpa exposta por cárie e compararam com o formocresol (FC). Uma amostra de 62 molares decíduos tratados por pulpotomia convencional foram divididos em 2 grupos: 33 dentes para o 
grupo MTA e 29 dentes para o grupo FC. As pulpotomias foram avaliadas por um período médio de 38 meses, sendo que 29 dentes foram avaliados até sua esfoliação normal. A taxa de sucesso foi de $97 \%$ para o grupo MTA (1 falha) e 83\% para o FC (5 falhas). Oito dentes apresentaram reabsorção interna. Quatro deles (2 de cada grupo), tiveram o processo de reabsorção interna paralisado, sendo que houve substituição por um tecido calcificado radiopaco. Obliteração do canal radicular foi observada em 58\% para o MTA e 52\% para o FC. O MTA mostrou uma taxa maior de sucesso (sem diferença estatística) em relação ao FC. Os autores recomendam o uso do MTA como substituto ao FC em pulpotomias de dentes decíduos, já que o MTA, ao contrário do FC, não induz respostas indesejáveis.

NAIK e HEGDE, em 2005, avaliaram a eficácia do MTA como medicamento para pulpotomia em dentes decíduos. 50 dentes decíduos com lesões de cárie e assintomáticos foram divididos em 2 grupos com 25 dentes cada: Grupo Formocresol (controle) e grupo MTA (experimental). Após a realização das pulpotomias, os dentes foram avaliados clinica e radiograficamente após 1, 3 e 6 meses. Nenhuma alteração clínica e radiográfica patológica foi encontrada nos períodos de avaliação. Somente foram encontradas alterações de cor nos dentes tratados com MTA. Os autores concluíram que a taxa de sucesso do MTA nesse estudo foi bastante elevada. Sugerem mais estudos com avaliações por períodos mais longos e com análise histológica dos dentes.

O objetivo do estudo retrospectivo de VARGAS e PACKHAM, em 2005, foi avaliar os achados radiográficos com relação à perda precoce de dentes submetidos à pulpotomias com formocresol ou com sulfato férrico. As pulpotomias feitas por 4 dentistas da Faculdade de Odontologia da Universidade de Lowa no período entre 1992 e 2002 foram avaliadas retrospectivamente. Ointenta e cinco dentes, com acompanhamento entre 6 e 61 meses, foram incluídos no estudo. Desses, 15 tratados com sulfato férrico, 23 tratados com formocresol e 5 tratados com a combinação de sulfato férrico e formocresol apresentaram ausência de patologia radiográfica. No total, $13 \%$ dos dentes pulpotomizados apresentaram perda prematura devido à presença de abscesso e necessitaram de aparelho para manutenção do espaço, sendo que o tipo de alteração mais freqüente relacionada à perda do dente decíduo foi reabsorção interna. Os autores concluíram que tanto o formocresol como o sulfato férrico pode levar a uma perda precoce do dente decíduo pulpotomizado, com a subseqüente necessidade de colocação de um aparelho ortodôntico para manutenção do espaço. Os autores 
ressaltam a importância da avaliação radiográfica periódica em dentes submetidos à pulpotomias.

CASAS et al. 2005, publicaram um artigo sobre a necessidade ou não do uso do formocresol em odontologia. Com o intuito de investigar qual o medicamento para pulpotomia em dentes decíduos é preconizado aos alunos de graduação, uma entrevista foi realizada com os diretores de programas de Odontopediatria de universidades do Canadá. O formocresol concentrado ou diluído foi relatado ser o mais utilizado, porém muitos programas de graduação oferecerem instruções didáticas alternativas ao formocresol, pouco menos de 1/3 oferecem alternativas que não sejam de métodos aldeídos. Apenas um programa não inclui o formocresol como treinamento clínico e didático para os alunos de graduação. Os autores relatam que os dentistas que argumentam que o formocresol não causa dano à saúde humana desconhecem o relato da Agência Internacional de Pesquisa com Câncer sobre a reclassificação do formaldeído como carcinogênico em humanos. Os autores ainda fornecem dados de medicamentos alternativos ao formocresol, com taxas de sucesso iguais ou superiores, como o MTA e o Sulfato férrico.

PENG et al., em 2006, realizaram uma meta-análise na qual compararam os efeitos clínicos e radiográficos do MTA e do formocresol quando utilizados em pulpotomias de molares decíduos humanos. Diante da análise de seis estudos selecionados através de critérios de inclusão, os autores encontraram diferença significante entre os dois materiais. O MTA mostrou melhores resultados clínicos e radiográficos além de menos respostas indesejáveis do que quando o formocresol foi utilizado, levando os autores a indicarem o uso do MTA em substituição ao formocresol como material de capeamento pulpar em pulpotomias de molares decíduos.

NEAMATOLLAHI e TAJIK, em 2006, compararam a taxa de sucesso do formocresol, sulfato férrico e MTA em pulpotomias de dentes decíduos. Foram selecionadas crianças com idade entre 3 e 6 anos, estas foram randomicamente divididas em 3 grupos: grupo fomocresol, grupo sulfato férrico e grupo MTA, totalizando 135 segundos molares decíduos. Após as pulpotomias, todos os dentes foram restaurados com amálgama. Os dentes foram avaliados clínica e radiograficamente com 3 e 12 meses do pós-operatório. A taxa de sucesso clínico para o grupo MTA foi 82,1\% após um ano de acompanhamento, a qual foi menor que a taxa de $100 \%$ observada no grupo formocresol. As maiores e menores taxas de 
sucesso radiográfico foram observadas, após 12 meses, para os grupos formocresol e MTA, respectivamente. Os autores recomendam o sulfato férrico como alternativa ao formocresol.

AEINEHCHI, et al., em 2007, compararam os resultados da aplicação de formocresol e MTA um pulpotomias de dentes molares decíduos após um período de proservação de 3 e 6 meses. Fizeram parte deste estudo crianças com idades entre 5 e 9 anos e com pelo menos 1 molar necessitando de pulpotomia. Após a divisão aleatória dos pacientes, os dentes foram tratados pela técnica convencional de pulpotomia. Um grupo (75 dentes) recebeu o formocresol por 5 minutos e em seguida teve a câmara pulpar preenchida com Zonalin. No outro grupo (51 dentes), uma camada de MTA (1mm) foi acomodada sobre os cotos pulpares. Ambos os grupos foram restaurados definitivamente com amálgama ou cimento de ionômero de vidro. Vinte e seis pacientes não retornaram para as avaliações, totalizando 100 dentes avaliados (57/formocresol e 43/MTA). Nenhum sinal de falha clínica foi observado em ambos os grupos após os períodos de 3 e 6 meses. Radiograficamente, as diferenças entre os grupos, aos 3 meses, não foram significantes. Entretanto, aos 6 meses, 6 dos 57 dentes tratados com formocresol apresentaram reabsorção interna e 4 alterações no tecido de suporte. Tais achados não foram encontrados em nenhum dos casos do grupo MTA. Diante dos resultados, os autores indicaram o MTA como material alternativo ao formocresol na realização de pulpotomias de dentes decíduos.

Com relação ao potencial de distribuição sistêmica do formaldeído, principal componente do formocresol, CORTÉS et al., em 2007, realizaram estudo com objetivo de determinar o risco de desenvolvimento de lesões no fígado de ratos após injeções endovenosas de formaldeído, simulando a quantidade dessa droga usada em pulpotomias. Trinta e dois ratos machos foram divididos em 4 grupos. No grupo 1 (controle), os ratos receberam injeção endovenosa de solução fisiológica; no grupo 2, receberam injeção endovenosa de formaldeído equivalente a 10 pulpotomias; no grupo 3, receberam injeção endovenosa de formaldeído equivalente a 20 pulpotomias e no grupo 4, equivalente a 100 pulpotomias. Foram feitas análises bioquímicas de transferases pelas amostras de sangue colhidas após 12 e 24 horas do início do experimento, bem como amostras do tecido hepático dos animais, após a eutanásia dos mesmos. O exame histológico mostrou que não houve dano ao tecido hepático e que esse se apresentava sem sinais de infiltrado inflamatório ou necrose em todos os grupos avaliados. A análise bioquímica mostrou que os níveis de transferases não foram diferentes entre o grupo controle e os grupos experimentais, 12 e 24 horas após a 
injeção endovenosa de formaldeído. Os autores concluíram que doses elevadas de formaldeído (maiores que em várias pulpotomias em uma única sessão) não foram danosas ao tecido hepático de ratos.

Também na busca de materiais que possam substituir com sucesso o formocresol, FORNETTI, em 2007, comparou o formocresol de Buckley em sua fórmula diluída a 1/5 com o cimento Portland em pulpotomias de dentes deíduos. Para tanto foram selecionadas 52 crianças entre 5 e 9 anos, totalizando 68 dentes. Estes foram divididos em 2 grupos conforme o material que foi utilizado como agente capeador na pulpotomia. Os dentes foram avaliados clínica e radiográficamente nos perídos de 3, 6 e 12 meses do pós-operatório, para análise do comportamento dos materiais. Os resultados do estudo mostraram que ambos os materiais são eficientes, sendo o cimento Portland um bom substituto para o formocresol.

PENG et al., em 2007, apresentaram uma revisão sistemática sobre os efeitos do formocresol e do sulfato férrico quando usados como medicamentos e pulpotomias de dentes decíduos. A lista de artigos que compuseram esta revisão foi obtida pela busca nas bases de dados MEDLINE, the Cochrane Library, EMBASE e SCI. Foram incluídos na pesquisa somente artigos que apresentavam critérios de inclusão, totalizando 11 estudos clínicos, dos quais 4 estudos clínicos randomizados, 4 estudos clínicos controlados e 3 estudos retrospectivos. Os resultados da meta-análise de 6 estudos clínicos prospectivos sugerem que os 2 medicamentos usados em pulpotomias de dentes decíduos não apresentaram diferença significativa em termos de resultados clínicos e radiográficos, prevalência de destruição óssea na área apical e de furca, reabsorção interna e obliteração radicular. No geral, a taxa de sucesso clínico e radiográfico para o sulfato férrico foi, respectivamente de $78 \%$ a $100 \%$ e de $42 \%$ a $97 \%$. Os autores concluíram que pulpotomias com formocresol ou com sulfato férrico apresentam resultados clínicos e radiográficos semelhantes. Ainda relatam que o sulfato férrico pode ser considerado um bom substituto ao formocresol em pulpotomias de dentes decíduos.

Com o objetivo de examinar as atitudes e práticas de Dentistas em Wales (Inglaterra) com relação ao medicamento usado em pulpotomias de dentes decíduos HINGSTON, PARMAR e HUNTER, em 2007, realizaram uma pesquisa por meio de questionários enviados pelo correio, 18 meses após a Agência Internacional de Pesquisa em Câncer liberar uma monografia re-classificando o formaldeído como cancerígeno em humanos. Dos 
questionários enviados, 78,2\% retornaram. Desses, uma amostra de 65 dentistas relataram utilizar a técnica de pulpotomia em seus consultórios. Os medicamentos mais utilizados por eles foram o formocresol (concentrado - 20,0\% ou diluído - 12,3\%), o paraformaldeído (32,2\%) e o sulfato férrico (29,2\%). Quarenta e sete dentistas (41,5\%) manifestaram preocupação com relação ao medicamento utilizado e 26,2\% consideraram uma possível mudança de técnica de pulpotomia. Além disso, somente 1 dentista entrevistado realiza exame radiográfico pré-operatório de rotina; somente 3 dentistas realizam acompanhamento radiográfico das pulpotomias. Somente $67,7 \%$ usam anestesia local para realização do tratamento, sendo o amálgama o material restaurador de escolha. Os autores sugerem, pelos resultados obtidos, que os dentistas em Wales necessitam de cursos de atualização profissional.

\subsection{Hidróxido de Cálcio}

Originalmente o hidróxido de cálcio apresenta-se como um sal cristalino, branco e suavemente solúvel. Em solução se dissocia em íons cálcio e íons hidroxila, de onde derivam suas propriedades biológicas e antimicrobianas, devido à ação desses íons sobre os tecidos, além de exibir uma alta alcalinidade ( $\mathrm{pH}$ 11). Em odontologia, o hidróxido de cálcio é usado por suas propriedades antimicrobianas e pela sua habilidade de induzir formação de tecido duro (WITHERSPOON et al., 2006).

A propriedade antibacteriana do hidróxido de cálcio está relacionada ao seu alto ph, este por sua vez promove a criação de um ambiente indesejável para o crescimento bacteriano. Existem 3 mecanismos pelos quais o hidróxido de cálcio induz a lise bacteriana: os íons hidroxila destroem fosfolipídeos e desta forma, destroem a membrana celular; - a alta alcalinidade promove a desnaturação das proteínas bacterianas; - os íons hidroxila reagem com o DNA bacteriano, inibindo sua replicação (FOREMAN e BARNES, 1990).

Atualmente são aceitas diversas teorias para explicar a formação de tecido duro pelo hidróxido de cálcio, entre elas podemos citar uma que sugere que a alta alcalinidade do material (ph 11), cria um ambiente favorável para a fosfatase alcalina, uma enzima envolvida no processo de mineralização. Esta enzima estimula a liberação dos íons fosfato, a partir dos ésteres de fosfato do organismo, que ao reagirem com os íons cálcio, se precipitam na forma de hidroxiapatita (ESTRELA, 1995). 
Outra teoria bastante aceita atualmente supõe que o hidróxido de cálcio, através de seus íons $\mathrm{Ca}^{2+}$ e $\mathrm{OH}^{-}$, apresenta um efeito na redução da permeabilidade de novos capilares, resultando em menor extravasamento de plasma e maior captura de cálcio da corrente sangüínea, favorecendo a resposta calcificante nos tecidos envolvidos. A presença dessa alta concentração de cálcio pode, também, aumentar ação da pirofosfatase, a qual é íons cálciodependente, favorecendo os mecanismos de defesa e reparo (FOREMAN e BARNES, 1990; CHACKO e KURIKOSE, 2006; WITHERSPOON et al., 2006). O esquema adaptado de Foreman e Barnes (1990) exemplifica a indução de mineralização pelo hidróxido de cálcio:

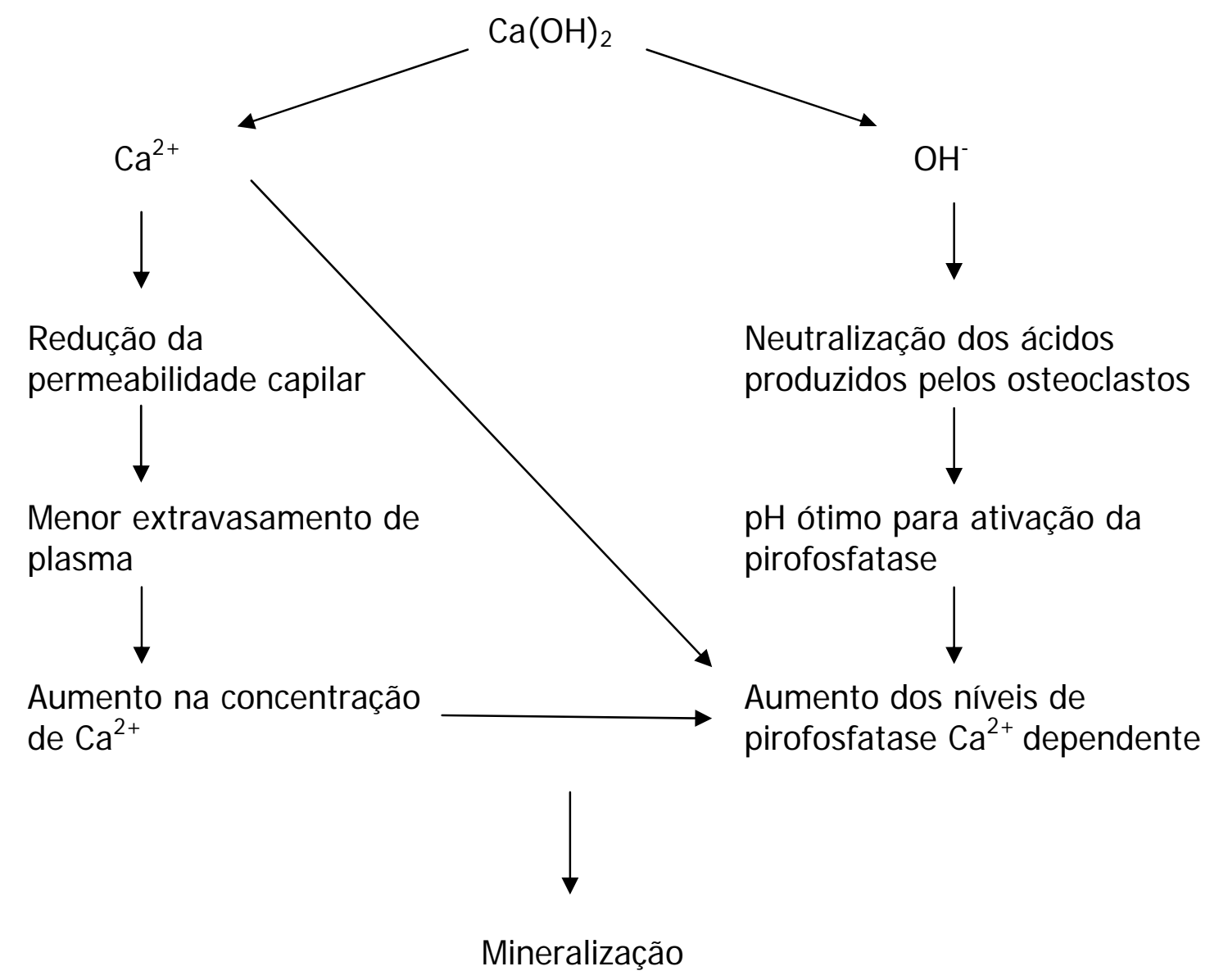


O objetivo do estudo de HEILIG, em 1984, foi de avaliar o efeito de duas diferentes soluções para controle da hemorragia em pulpotomias com hidróxido de cálcio. Uma amostra contendo 17 molares decíduos inferiores foi dividida em 2 grupos: Grupo I - pulpotomia com cimento de hidróxido de cálcio precedida por solução de água estéril como agente hemostático; e grupo II - pulpotomia com cimento de hidróxido de cálcio precedida por solução de cloreto de alumínio como agente hemostático. Os dentes foram avaliados clínica e radiograficamente após 6 semanas, 3, 6 e 9 meses. Os achados radiográficos foram mais favoráveis no grupo II. Ao final do estudo, 15 dentes apresentaram sucesso clínico e radiográfico, sendo que 2 dentes do grupo controle (grupo I) apresentaram insucesso radiográfico (1 aos 6 meses e 1 aos 12 meses). As falhas foram demonstradas por reabsorção interna e alterações no trabeculado ósseo. Os autores sugerem que o cloreto de alumínio pode ser usado em pulpotomias com hidróxido de cálcio, porém ressaltam a importância de mais estudos em longo prazo, além de estudos histológicos para confirmar essa sugestão.

FADAVI e ANDERSON, em 1996, avaliaram a resposta de cicatrização pulpar ao osso endurecido congelado humano (FDB). Para tanto, 36 dentes decíduos não cariados de 2 macacos foram divididos aleatoriamente em 3 grupos, nos quais foram realizadas pulpotomias com FDB, hidróxido de cálcio e IRM ${ }^{\circledR}$, em seguida todos os dentes foram restaurados com amálgama. Um animal foi sacrificado com 6 semanas e o outro com 6 meses de pósoperatório. Os dentes foram extraídos e preparados para análise histológica. Os resultados mostraram que 100\% dos dentes tratados com FDB apresentavam polpa vital quando comparados com 75\% dos dentes tratados com hidróxido de cálcio após 6 semanas. Barreira dentinária estava presente em 87,5\% dos dentes do grupo FDB comparados com 75\% do grupo hidróxido de cálcio. Células inflamatórias estavam ausentes ou em pequenas quantidades em 100\% dos dentes tratados com FDB comparados com 75\% dos tratados com hidróxido de cálcio. Após 6 meses, 83,3\% dos dentes tratados com FDB apresentavam polpa vital comparados com os tratados com hidróxido de cálcio, os quais apresentaram necrose pulpar em 100\%. A barreira dentinária estava presente em 100\% dos dentes do grupo FDB e em $50 \%$ dos dentes do grupo hidróxido de cálcio. Os dentes tratados com IRM ${ }^{\circledR}$ mostraram necrose pulpar após 6 meses. Os autores concluíram que o FDB foi superior ao hidróxido de cálcio quando utilizados em pulpotomias de dentes decíduos em macacos.

PITT FORD et al., em 1996, examinaram a resposta pulpar de dentes de macaco ao MTA e ao hidróxido de cálcio, usados como materiais para capeamento pulpar. Polpas de 12 
incisivos inferiores foram expostas com broca esférica e as mesmas foram capeadas com MTA ou hidróxido de cálcio. Após cinco meses, os autores verificaram ausência de inflamação em 5 de 6 amostras capeadas com MTA, e completa formação de barreira dentinária em todas as amostras deste grupo. Em contraste, todas as polpas capeadas com hidróxido de cálcio mostraram reação inflamatória e a barreira dentinária ocorreu somente em 2 casos. Os autores concluíram que o MTA possui potencial para ser utilizado como material capeador em terapias de polpas vitais.

SOARES, em 1996, avaliou por meio de um estudo histológico a resposta pulpar de dentes de cães, ao MTA comparada ao hidróxido de cálcio. Para tanto foram realizadas 12 pulpotomias onde as polpas foram capeadas com pasta de hidróxido de cálcio em propileno glicol (Grupo I) e 28 pulpotomias, as quais foram capeadas com MTA (Grupo II). Sobre o material capeador foi colocado uma camada de cimento de hidróxido de cálcio e os dentes foram restaurados com amálgama. Após 90 dias, os animais foram sacrificados e as peças removidas e processadas para análise histológica. Quanto à formação de barreira de tecido mineralizado, a autora observou valores de 91,66\% e 96,43\% para os grupos hidróxido de cálcio e MTA, respectivamente. Os percentuais de casos que apresentaram, simultaneamente, barreira de tecido mineralizado e tecido pulpar normal foi de 66,66\% para os espécimes tratados com hidróxido de cálcio, e de 82,14 para os tratados com MTA. A autora concluiu que existe semelhança entre os 2 materiais testados quanto ao comportamento frente ao tecido pulpar.

Visando comparar duas diferentes técnicas de pulpotomia (Formocresol de Buckley diluído a 1/5 e hidróxido de cálcio puro), WATERHOUSE, NUNN e WHITWORTH, em 2000, realizaram avaliações clínicas e radiográficas durante um período de 24 meses. Participaram do estudo crianças entre 3 e 12 anos de idade, totalizando oitenta e quatro dentes que foram divididos aleatoriamente em dois grupos: grupo $\mathrm{F}$ - pulpotomia com formocresol (46 dentes) e grupo C - pulpotomia com hidróxido de cálcio (38 dentes). Após a pulpotomia os dentes eram restaurados com amálgama, cimento de ionômero de vidro ou compômero e avaliados, clínica e radiograficamente de 6 em 6 meses até 24 meses. Os autores confirmam a eficácia do formocresol Buckley diluído a 1/5, com 100\% de sucesso clínico e radiográfico, como agente utilizado em pulpotomia de dentes decíduos. O grupo hidróxido de cálcio apresentou taxa de 83\% de sucesso clínico e radiográfico e os autores relatam que o hidróxido 
de cálcio pode ser uma alternativa aceitável, desde que a seleção dos casos de pulpotomia seja criteriosa e a restauração do dente seja realizada da melhor maneira possível.

ROCHA et al., em 2000, realizaram 14 pulpotomias em molares decíduos de pacientes entre 4 e 7 anos de idade. Nove dentes receberam pulpotomias com hidróxido de cálcio e propilenoglicol e 5 dentes receberam pulpotomias com MTA e água destilada. Todos dentes foram restaurados com cimento de ionômero de vidro e resina. Os autores realizaram avaliações clínica e radiograficamente 3, 6, 9 e 12 meses após o tratamento. Foi considerado sucesso quando o dente não apresentava mobilidade, dor espontânea ou provocada, rarefação perirradicular, fístula e reabsorção interna. A reabsorção externa deveria estar ocorrendo na mesma velocidade que o dente contra-lateral. Dos nove casos realizados com hidróxido de cálcio, oito apresentaram sucesso e todos os dentes que foram tratados com MTA apresentaram sucesso.

ALCURE, em 2001, buscou avaliar a presença e as características morfológicas microscópicas da barreira dentinária formada após capeamento direto com hidróxido de cálcio em polpas de dentes permanentes humanos. As avaliações foram realizadas nos períodos de 45, 90 e 120 dias após a realização do tratamento. Os resultados permitiram constatar que a barreira de tecido mineralizado induzida pelo hidróxido de cálcio estava bem constituía aos 45 dias, possuindo estrutura dentinária em virtude de sua organização e padrão tubular, nas suas camadas mais profundas. As camada mais superficiais apresentaram um padrão de mineralização distrófica, comumente com padrão de osteodentina e em continuidade estrutural com a parede dentinária remanescente da parede cavitária. A autora concluiu que a barreira de tecido mineralizado induzida pelo hidróxido de cálcio após exposição pulpar em dentes permanentes humanos isola a polpa do material restaurador.

AEINEHCHI et al., em 2003, comparam a ação do MTA e do hidróxido de cálcio quando utilizados em capeamentos pulpares. Para a pesquisa foram realizadas exposições pulpares provocadas mecanicamente em 22 terceiros molares superiores de indivíduos entre 20 e 25 anos. As polpas expostas foram capeadas ou com MTA ou com hidróxido de cálcio, cobertas com uma base de OZE e os dentes restaurados com amálgama. Um total de 14 dentes foi extraído após: 1 semana - 2 molares; 2 meses - 3 molares; 3 meses - 5 molares; 4 meses 2 molares e 6 meses - 2 molares. A avaliação histológica demonstrou menos reação inflamatória, hiperemia e necrose, barreira dentinária mais espessa e formação mais freqüente 
de camada odontoblástica nos dentes capeados com MTA que os capeados com hidróxido de cálcio. Os autores concluíram que o MTA apresenta resultados favoráveis, porém sugerem mais estudos com amostras maiores.

No estudo de DOMINGUEZ et al., em 2003, foram realizados pulpotomias e capeamentos pulpares em 15 cães, nos quais, além de um grupo controle, três materiais foram usados: hidróxido de cálcio, adesivo dentinário e MTA. Seis cães foram sacrificados aos 50 dias e nove aos 150 dias para análise dos materiais. Onze cães foram usados para avaliação histológica e o restante para análise por microscopia eletrônica de varredura. A análise por microscopia eletrônica de varredura foi realizada, e a porcentagem de peso dos elementos encontrados na dentina de dentes controle (não tratados) versus a ponte de dentina formada nos espécimes tratados foi analisada. Pela avaliação da inflamação pulpar em tratamento de polpa vital, foi encontrado que o MTA não foi significativamente diferente do grupo controle, tanto em capeamentos pulpares como em pulpotomias aos 50 e 150 dias. Além disso, histologicamente, o MTA foi considerado melhor que o hidróxido de cálcio ou adesivo dentinário na manutenção da integridade pulpar, em avaliações de longo prazo, ou seja, o MTA com o tempo, apresenta melhores respostas pulpares que os outros materiais testados.

MENEZES, em 2004, realizou em estudo com objetivo de estabelecer, através da definição da dose $\mathrm{TD}_{50}$ (concentração que causa a morte de $50 \%$ das células) uma escala de toxicidade dentre diversas substâncias comumente utilizadas em pulpotomias de dentes decíduos. Foram utilizadas como substâncias-testes o formocresol concentrado (FC), formocresol diluído a 1/5 (FCD), solução de sulfato de ferro a 15,5\% (SF), hidróxido de cálcio P. A. (HC) e o agregado trióxido mineral (MTA). Fibroblastos Balb-c 3T3 foram semeados em placa de cultura de 24 poços. Diluições variadas dos extratos das substânciastestes foram colocadas em contato com as células por 24 horas para a determinação da $\mathrm{TD}_{50}$. Os ensaios colorimétricos de redução do MTT e captação do corante Vermelho Neutro (VN) foram realizados na $\mathrm{TD}_{50}$ das substâncias-testes. Baseado na definição da $\mathrm{TD}_{50}$ pode ser estabelecida uma escala de citotoxicidade em ordem decrescente, a saber: FC $>$ FCD $>$ SF $>$ HC $>$ MTA. Os ensaios para a determinação da capacidade de redução do MTT e incorporação do VN demonstraram que a citotoxicidade dos materiais testados afeta, primordialmente, a função mitocondrial em detrimento do efeito mais discreto na integridade da membrana. Além da determinação de uma escala de potência adequada para a ordenação 
de compostos terapêuticos em função de sua toxicidade, conclui-se que os materiais testados têm sua toxicidade mediada principalmente por alterações da função mitocondrial das células.

CENGIZ et al., em 2005, propôs avaliar o potêncial do alendronato de sódio na estimulação de tecido duro em molares pulpotomizados de ratos. O alendronato de sódio é um bifosfonato que tem potencial de inibir reabsorção óssea e é bastante empregado em medicina, principalmente no tratamento da osteoporose. Para o estudo foram utilizados 24 ratos machos de 3 a 5 meses de idade. Pulpotomias foram realizadas com 3 diferentes materiais: Formocresol (FC), hidróxido de cálcio (HC) e alendronato de sódio (ALN) e todos os dentes foram restaurados com amálgama. Nos períodos pós-operatórios de 7, 15, 30 e 60 dias os animais foram sacrificados e as maxilas e mandíbulas com os dentes tratados foram preparados para análise histológica, de acordo com os critérios de resposta celular inflamatória, desorganização tecidual e formação de tecido duro. Em todos os períodos avaliados, a deposição de tecido mineralizado foi evidente por toda a dentina radicular nos grupos ALN e HC, sendo que nos períodos de 30 e 60 dias esses dois grupos não apresentaram diferença significativa quanto à resposta inflamatória e deposição de tecido mineralizado. Os autores relatam que o ALN parece ser capaz de manter a vitalidade pulpar enquanto promove a formação de tecido duro, similar ao HC.

Devido a falta de evidências sobre qual a técnica mais apropriada para a realização de pulpotomia em dentes decíduos, HUTH et al., em 2005 compararam a efetividade do laser Er:YAG, do hidróxido de cálcio e do sulfato férrico (15,5\%) com o formocresol (solução diluída a 1/5) quando empregados neste procedimento. Duzentos molares decíduos de 107 crianças foram randomizadamente alocados em uma das técnicas. Os dentes tratados foram cegamente avaliados nos períodos de 6, 12, 18 e 24 após o tratamento. Decorridos os 24 meses, as taxas de sucesso clínico foram determinadas sendo: 96\% para o grupo do formocresol, 93\% para o laser, 87\% para o hidróxido de cálcio e 100\% para o grupo do sulfato férrico. Apenas os resultados do hidróxido de cálcio foram considerados significantemente piores do que os do formocresol. Assim, os autores concluíram que o hidróxido de cálcio é o menos apropriado para a realização de capeamento pulpar após pulpotomia de dentes decíduos, quando comparado ao formocresol.

ALBUQUERQUE, GOMINHO e SANTOS, em 2006, avaliaram os aspectos histológicos do complexo dentino-pulpar de cães submetidos a pulpotomias com etil- 
cianoacrilato (um adesivo com propriedade hemostática, bactericida e também pode induzir o reparo tecidual pela diminuição no grau e tempo de resposta inflamatória e hidróxido de cálcio. Trinta dentes permanentes de cães adultos foram divididos em 2 grupos: Grupo 1 pulpotomia com etil-cianoacrilato e grupo 2 - pulpotomia com hidróxido de cálcio. Após a pulpotomia, os dentes foram restaurados com amálgama. Depois de 30 dias do procedimento realizado os espécimes foram submetidos ao preparo histológico e logo após, foram avaliados de forma cega por um histologista e os resultados foram analisados estatisticamente, comparando os 2 grupos. Os aspectos analisados foram a formação de barreira de tecido duro e as condições do tecido pulpar. No grupo 1, 83,3\% e no grupo 2, $100 \%$ dos dentes apresentaram barreira de tecido duro. Barreira contínua foi observada em 50\% dos casos tratados com etil-cianoacrilato e em 75\% daqueles tratados com hidróxido de cálcio. Os autores concluíram que tanto o grupo 1 como o grupo 2 induziram a formação de barreira de tecido duro, porém o grupo 2 apresentou um percentual maior do que o grupo 1, não havendo diferença estatisticamente significante. Necrose pulpar não foi observada em nenhum grupo.

O objetivo do estudo de BRISO et al., em 2006, foi observar a resposta da polpa dentária de cães ao capeamento com MTA ou hidróxido de cálcio P.A. Para tanto, 37 dentes foram divididos em 2 grupos, de acordo com o material capeador utilizado. Dois cães foram anestesiados e após o isolamento absoluto do campo operatório, foram realizados exposições pulpares padronizadas, proteção com os materiais capeadores testados e selamento das cavidades com cimento de ionômero de vidro modificado por resina. Os dentes foram restaurados com resina composta. Após 60 dias, os animais foram sacrificados e as peças foram processadas para análise microscópica dos dentes. Os autores observaram maior índice de sucesso do MTA comparado ao hidróxido de cálcio, evidenciando menor ocorrência de infecção e necrose pulpar.

TUNÇ et al., em 2006, avaliaram o efeito do hipoclorito de sódio a 3\% usado como agente hemostático em pulpotomias com hidróxido de cálcio em dentes decíduos. Dezoito molares decíduos com cárie avançada e metade da raiz reabsorvida foram randomicamente divididos em 2 grupos. Pulpotomias convencionais com hidróxido de cálcio foram realizadas em ambos os grupos, porém o segundo grupo recebeu a aplicação uma bolinha de algodão embebida com solução de hipoclorito de sódio a 3\% por 30 segundos para controle da hemorragia, antes da colocação do material capeador. Os dentes foram avaliados clinica e radiograficamente 3 e 6 meses do pós-operatório. Após esse período, os dentes foram 
extraídos e preparados para avaliação histológica. Na avaliação de 6 meses, 1 dente do grupo tratamento mostrou falha radiográfica representada por reabsorção interna. A análise radiográfica mostrou que nenhum espécime do grupo controle apresentou necrose e 1 espécime do grupo tratamento apresentou necrose parcial. Os autores concluíram que o uso do hipoclorito de sódio a 3\% como agente hemostático não apresentou efeito nas pulpotomias com hidróxido de cálcio, na concentração e período de tempo estipulado nesse estudo.

A proposta do estudo de CHACKO e KURIKOSE, em 2006, foi avaliar as alterações histológicas na polpa dentária após pulpotomia com MTA ou hidróxido de cálcio. Foram feitas pulpotomias em pré-molares indicados para extração por razões ortodônticas. O remanescente pulpar foi coberto com MTA ou com hidróxido de cálcio e foram restaurados com IRM. Os dentes foram extraídos no intervalo de 4 a 8 semanas e preparados para análise microscópica. As polpas capeadas com MTA (no final de 4 e 8 semanas) mostraram formação de barreira dentinária, as quais se mostraram mais homogêneas e maior continuidade com a dentina original que as polpas capeadas com hidróxido de cálcio. Inflamação pulpar também foi menor no grupo MTA que no grupo hidróxido de cálcio no final de 4 e 8 semanas.

O objetivo do estudo de SARI, SONMEZ e CETINBAS, em 2007, foi comparar o efeito do formocresol (FC), sulfato férrico (SF), hidróxido de cálcio (HC) e agregado trióxido mineral (MTA) como agentes capeadores em pulpotomias de dentes decíduos. Oitenta dentes decíduos foram divididos em 4 grupos após a pulpotomia. Avaliações clínicas e radiográficas foram realizadas a cada 6 meses durante 2 anos e revelaram os seguintes resultados: 79,92\% para o grupo FC; 73,33 para o SF; 46,15\% para o HC e 66,66\% para o MTA. Os autores concluíram que o HC é o material menos apropriado para pulpotomias de dentes decíduos, enquanto que os outros agentes mostraram resultados superiores.

ACCORINTE et al., em 2008, avaliaram a resposta pulpar de dentes humanos após capeamento direto realizado com MTA ou com HC. Para tanto foram realizadas exposições pulpares de tamanho padronizado em 40 pré-molares sem cárie, com indicação para exodontia por motivos ortodônticos. Os dentes foram divididos em 4 grupos, grupo 1 (HC30) e 2 (HC60), estes receberam capeamento direto com cimento de hidróxido de cálcio e os grupos 3 (MTA30) e 4(MTA60) receberam capeamento direto com MTA. Após a inserção do material capeador, foi aplicada uma camada de cimento de ionômero de vidro forrador e os dentes foram restaurados com resina composta. Após 30 dias, os dentes dos grupos 1 e 3 foram 
extraídos e após 60 dias, os dentes dos grupos 2 e 4. Todos os dentes foram preparados para análise histomorfológica. Com relação à formação de barreira de tecido mineralizado, o MTA mostrou melhores resultados que o HC após 3 meses da realização dos capeamentos. No entanto, após 6 meses, não houve diferença entre os materiais.

MORETTI, em 2008, realizou um trabalho avaliando pulpotomias clínica, radiográfica e microscopicamente os efeitos do formocresol de Buckley diluído a 1/5, hidróxido de cálcio e do agregado trióxido mineral (MTA). Nesse estudo foram selecionados 45 dentes que foram divididos em 3 grupos separados conforme o material utilizado no capeamento pulpar após a pulpotomia. Os dentes foram avaliados clínica e radiograficamente aos 3, 6, 12, 18, 24 e 30 meses de pós-operatório. Decorrida a análise radiográfica de 30 meses os dentes foram extraídos e preparados para a análise microscópica. A autora concluiu que os materiais formocresol e MTA proporcionam uma resposta satisfatória do complexo dentino-pulpar, e o material hidróxido de cálcio não apresentou respostas satisfatórias.

\subsection{Antiinflamatório}

Um dos problemas que sempre preocupou aqueles que se dedicam ao estudo do tratamento conservador da polpa dental, diz respeito a indagações sobre a existência de uma possível relação entre o grau de inflamação e o tipo de tratamento e medicamento a ser ministrado (HOLLAND, 1971).

Na endodontia de dentes permanentes o uso de um “curativo de demora” empregando uma associação de corticosteróide e antibiótico é uma técnica já bastante consagrada na literatura e apresenta grande eficácia. O mesmo pode ser aplicado para a técnica da pulpotomia, mais especificamente na técnica mediata, realizada em duas sessões, onde essa associação medicamentosa é utilizada de 48 a 72 horas de forma tópica.

Porém alguns autores já sugerem o uso desse tipo de medicação tópica por 5 à 10 minutos nos casos de pulpotomia, funcionando como uma medicação antiinflamatória de reforço, atenuando a intensidade da reação inflamatória provocada devido à evolução da lesão de cárie e também pelo ato cirúrgico, reduzindo o aumento da pressão pulpar interna, o que poderia vir a prejudicar o reparo da polpa remanescente, pois a mesma se encontra contida por paredes inextensíveis (ESTRELA, 2004). 
A reação inflamatória é tida como um fenômeno necessário para o completo e normal desenvolvimento do processo de reparação. O que se espera da terapia com uso de corticosteróides é minimizar a reação inflamatória inicial de modo que a mesma não atinja níveis excessivos, capazes de provocar danos teciduais mais severos. Pois existe uma relação entre a intensidade da reação inflamatória e o resultado do tratamento, por haver uma menor possibilidade da polpa de se recuperar completamente deste processo inflamatório. Soma-se a isso o fato de que exames histológicos mostraram que, na maioria dos casos, a inflamação localiza-se na polpa coronária, permanecendo a polpa radicular normal ou pouco comprometida.

Os corticóides mais empregados em Endodontia são a hidrocortisona, a prednisolona e a dexametasona, sendo que a associação destes com outros medicamentos e alguns produtos comerciais tem sido sugeridos na terapia endodôntica. Entre eles o Otosporin ${ }^{\circledR}$ (Farmoquímica S/A) proposto por Holland em 1975, que consiste na associação da hidrocortisona com os antibióticos sulfato de polimixina B e sulfato de neomicina, em veículo aquoso, tem sido bastante empregado.

HOLLAND, et al., em 1971, realizou uma pesquisa empregando diferentes associações medicamentosas em polpas sãs, após pulpotomia e em seguida protegendo o remanescente pulpar com hidróxido de cálcio. Nessa pesquisa foram utilizados dentes anteriores de 16 cães com idade entre 1 e 2 anos, os dentes foram pulpotomizados e divididos em oito diferentes grupos, cada um com um tipo de curativos de demora aplicado por 48 horas, decorrido este período os dentes foram extraídos e analisados em cortes histológicos. Os melhores resultados foram obtidos com o emprego dos corticosteróides, mais especificamente a hidrocortisona, sendo que algumas associações com antibióticos também apresentaram bons resultados.

AYDOS, em 1985, em um estudo bastante amplo avaliou os diferentes tipos de diagnóstico e tratamentos para a polpa dental inflamada. Pacientes na faixa etária de 12 a 40 anos com necessidade de pulpotomia foram selecionados, sendo que um total de 52 dentes receberam pulpotomias pela técnica mediata com medicação por 48 horas, sendo os dentes divididos em 4 grupos de acordo com o medicamento utilizado. Na segunda sessão os remanescentes foram recobertos com hidróxido de cálcio e os dentes restaurados definitivamente. O controle pós-operatório foi realizado em dois momentos, imediatamente após a pulpotomia, obtendo $100 \%$ de alívio da dor, e 6 e 18 meses após a realização da 
pulpotomia de forma clínica e radiográfica. Os autores obtiveram 94,3\% de sucessos no grupo que recebeu a medicação antiinflamatória, o que comprova a eficácia do corticosteróide associado à pulpotomia.

Com o objetivo de avaliar diferentes tipos de medicamentos anti-inflamatórios utilizados em pulpotomias SAW e THONG, em 1993, selecionaram 9 cães, utilizando os incisivos e pré-molares dos mesmos em sua pesquisa. Os dentes foram pulpotomizados e divididos em 5 grupos segundo o tipo de medicamento utilizado, formocresol de Buckley, cimento Ledermix, corticoteróide, berbamine e tetradine. Decorridos os períodos de 3 dias e 6 semanas os animais foram sacrificados e aslâminas histológicas confeccionadas. Os cortes histológicos realizados com 3 dias de pós-operatório demonstraram um intenso infiltrado inflamatório para os grupos formocresol de Buckey e cimento Ledermix, os demais grupos apresentaram um infiltrado moderado ou fraco. Já para o controle de 6 semanas, os dentes que receberam medicação antiinflamatória apresentaram nenhum ou um infiltrado inflamatório bem fraco, e os demais grupos apresentaram um infiltrado moderado. Ao final os autores concluíram que as pulpotomias realizadas com medicamento antiinflamatório apresentam menos infiltrado inflamatório do que aquelas realizadas com formocresol e cimento Ledermix.

O objetivo do estudo de TEIXEIRA e TANCREDO, em 1994, foi de avaliar clínica e radiográficamente o índice de sucesso das pulpotomias realizadas de forma imediata e mediata, em ambas com a utilização de uma associação de corticosteróide-antibiótico $\left(\right.$ Otosporin $^{\circledR}$ ). Foram estabelecidos dois grupos, com 40 primeiros molares permanentes cada, de crianças comidade entre 7 e 14 anos, para o grupo I, da pulpotomia imediata o medicamento foi aplicado por 10 minutos e em seguida o remanescente foi recoberto com hidróxido de cálcio e no grupoII, pulpotomia em duas sessões o medicamento foi deixado por 7 dias e em seguida o mesmo foi realizado. Od dentes foram acompanhados clínica e radiograficamente nos períodos de 3 e 6 meses, e os autores obtiveram como resultados 92,3\% de sucesso para o grupo I com 63,8\% de formação de barreira dentinária e para o grupo II 89,1\% de sucesso e 45,4\% de formação de barreira dentinária. Os autores puderam concluir que a técnica imediata apresenta vantagens sobre a técnica mediata por se realizar em sessão única e que o uso de medicamento em ambos os grupos auxiliou no reparo da polpa. 
SOUZA, HOLLAND e SOUZA, em 1995, estudaram a influência do uso de curativos de demora no processo de reparo dos tecidos periapicais. Nessa pesquisa foram utilizaram-se 128 raízes de dentes de cães divididas em 4 grupos distintos, grupo I óxido de zinco e eugenol sem curativo de demora; grupo II hidróxido de cálcio sem curativo de demora; grupo III curativo de demora com corticosteróide-antibiótico e obturação com óxido de zinco e eugenol; grupo IV curativo de demora com hidróxido de cálcio e obturação com óxido de zinco e eugenol. As raízes foram analisados histologicamente 7 ou 180 dias após o tratamento. Decorridos os dois períodos de avaliação os autores puderam concluir que à curto prazo, no período de 7 dias o uso da associação corticosteróide-antibiótico como curativo de demora diminuiu de forma expressiva o processo inflamatório, e a médio prazo, no período de 180 dias não houve uma diferença estatisticamente significante entre os grupos, comprovando a eficácia do medicamento em curtos períodos.

A pesquisa realizada por LEONARDO, UTRILLA e SILVA, em 1996, teve como objetivo avaliar histologicamente o comportamento dos tecidos apicais e pericapicais, após a colocação de diferentes curativos de demora nos períodos de 7, 15 e 30 dias. Foram utilizados 120 raízes de dentes de cães, divididas em 5 grupos conforme o medicamento utilizado para o curativo de demora, sendo que o grupo IV foi o controle positivo, onde se esperava a ausência de inflamação, o canal foi preenchido com uma associação de corticosteróide-antibiótico $\left(\right.$ Otosporin $^{\circledR}$ ). Na analise histológica ficou comprovada a eficácia antiinflamatória do medicamento, pois nos três períodos de avaliação observou-se apenas uma discreta presença de células inflamatórias, normais ao processo de reparação da polpa, e nenhum infiltrado inflamatório.

HOLLAND, et al., em 1998, avaliaram o comportamento do hidróxido de cálcio e da associação corticosteróide-antibiótico (Otosporin ${ }^{\circledR}$ ) como curativo de demora e seus respectivos efeitos antiinflamatórios na região periapical. Sessenta canais de dentes de cães foram utilizados e divididos em 2 grupos conforme o medicamento do curativo de demora e em seguida em outros grupos conforme o material obturador usado na segunda sessão após a remoção do curativo. Os curativos permaneceram nos canais por um período de 7 dias, em seguida os dentes foram obturados, e após 180 dias foram realizados os cortes histológicos. Com a análise dos resultados os autores puderam observar que $80 \%$ dos canais que receberam o curativo de demora com o medicamento Otosporin ${ }^{\circledR}$ não apresentaram nenhuma reação inflamatória, nos casos onde se observou reação inflamatória, atribui-se a mesma ao 
extravasamento de material no ápice radicular, comprovando-se assim a eficácia antiinflamatória do medicamento utilizado.

Em um estudo realizado por PRECINOTO, CASTRO e PINTO, em 2006, todas as 90 pulpotomias realizadas em primeiros molares de crianças de 3 a 8 anos foram feitas em duas sessões, fazendo uso de uma associação de corticosteróide-antibiótico (Otosporin ${ }^{\circledR}$ ) por 48 horas como medicação de demora antes da colocação do material capeador a ser estudado. Tal metodologia foi aplicada, pois os autores comprovaram que além da correta indicação do material para o capeamento pulpar, a presença de um infiltrado inflamatório muito avançado pode influenciar negativamente no processo de reparo da polpa dental. Sendo assim a utilização de um curativo de demora reduz ou elimina a inflamação, aumentando a capacidade de reparo e prevenindo a irritação da polpa. 


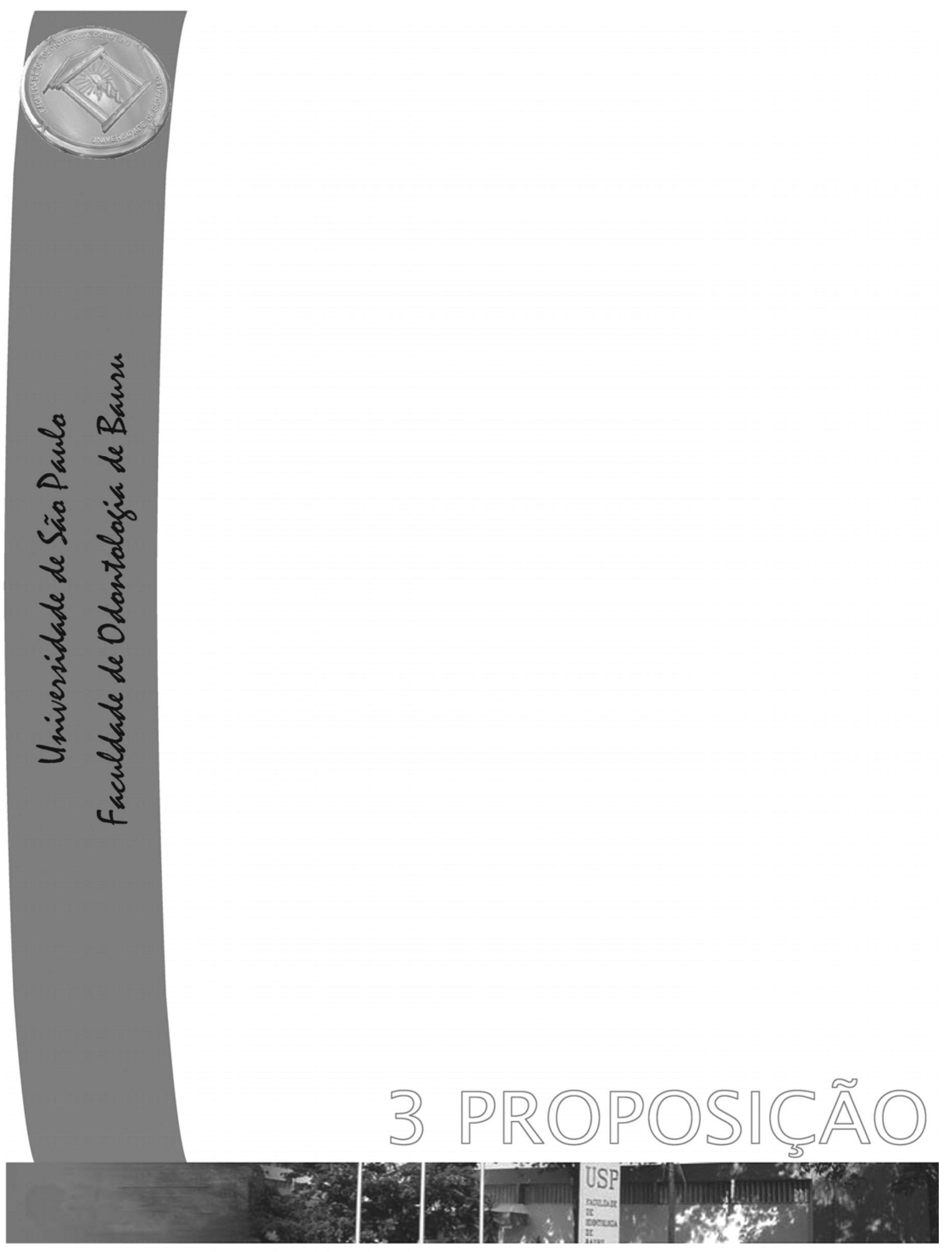




\section{PROPOSIÇণ̃̃ิO}

O propósito deste estudo foi verificar, in vivo, a resposta do complexo dentino-pulpar de dentes decíduos após pulpotomia com os materiais: formocresol de Buckley diluído a 1/5, hidróxido de cálcio PA, e hidróxido de cálcio PA precedido pelo antiinflamatório Otosporin ${ }^{\circledR}$.

Avaliar e comparar o procedimento de pulpotomia realizado nos diferentes grupos (materiais), através de exames clínicos e radiográficos, imediatamente após a realização da pulpotomia, 3, 6 e 12 meses.

\subsection{Hipóteses}

H0 - Não existe diferença estatisticamente significativa entre os grupos estudados.

H1 - Existe diferença estatisticamente significativa entre os grupos estudados. 


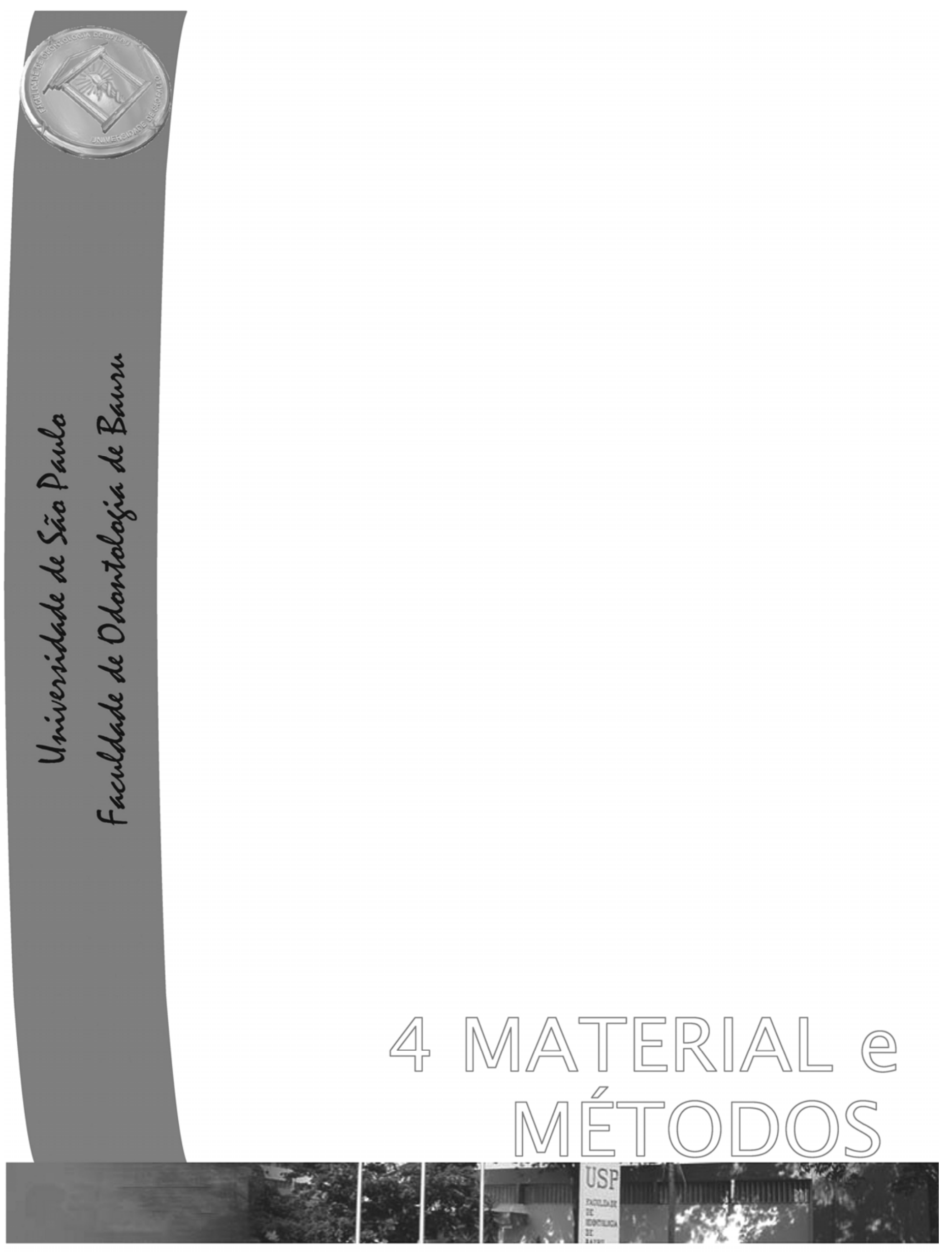




\section{MATERIALE MÉTODOS}

\subsection{Comitê de ética}

Seguindo princípios éticos e jurídicos, a realização deste trabalho foi avaliada e aprovada pelo Comitê de Ética em Pesquisa em Humanos da Faculdade de Odontologia de Bauru - Universidade de São Paulo, protocolo 62/2007 (Anexo 1)

\subsection{Seleção da amostra e determinação dos grupos}

Neste estudo, foram realizadas 45 pulpotomias em dentes decíduos de 35 crianças de 5 a 9 anos de idade - média de 6 anos e 6 meses (Quadro 1), de ambos os sexos.

\begin{tabular}{|c|c|c|c|c|c|c|c|c|}
\hline \multicolumn{3}{|c|}{ FC } & \multicolumn{3}{|c|}{$\mathrm{HC}$} & \multicolumn{3}{|c|}{ HC + Antiinflamatório } \\
\hline Paciente & dente & Idade & Paciente & dente & Idade & Paciente & dente & Idade \\
\hline 1 & 84 & 6a $8 m$ & 1 & 84 & 5a $9 \mathrm{~m}$ & 1 & 74 & $8 \mathrm{a} 1 \mathrm{~m}$ \\
\hline 2 & 74 & $8 \mathrm{a} 6 \mathrm{~m}$ & 2 & 84 & 6a $8 \mathrm{~m}$ & 2 & 84 & 7a $1 \mathrm{~m}$ \\
\hline 3 & 75 & 6a $2 \mathrm{~m}$ & 3 & 84 & $8 \mathrm{a} 4 \mathrm{~m}$ & 3 & 74 & 7a $4 \mathrm{~m}$ \\
\hline 4 & 75 & 6a $1 \mathrm{~m}$ & 4 & 74 & 8a 4m & 4 & 74 & 8a $7 \mathrm{~m}$ \\
\hline 5 & 85 & 5a $8 \mathrm{~m}$ & 5 & 74 & $6 a$ & 5 & 74 & 6a $11 \mathrm{~m}$ \\
\hline 6 & 85 & $8 \mathrm{a} 4 \mathrm{~m}$ & 6 & 84 & $6 a$ & 6 & 84 & 6a $11 \mathrm{~m}$ \\
\hline 7 & 74 & $8 \mathrm{a} 4 \mathrm{~m}$ & 7 & 85 & 9a 4m & 7 & 84 & 7a $2 \mathrm{~m}$ \\
\hline 8 & 75 & 6a $2 \mathrm{~m}$ & 8 & 85 & $5 a 8 m$ & 8 & 84 & 6a $5 \mathrm{~m}$ \\
\hline 9 & 84 & $6 a$ & 9 & 75 & 5a $8 \mathrm{~m}$ & 9 & 85 & 6a $6 \mathrm{~m}$ \\
\hline 10 & 85 & $6 a$ & 10 & 85 & $8 \mathrm{a} 6 \mathrm{~m}$ & 10 & 75 & $8 \mathrm{a} 8 \mathrm{~m}$ \\
\hline 11 & 84 & $6 a$ & 11 & 74 & 6a 3m & 11 & 84 & 7a $1 \mathrm{~m}$ \\
\hline 12 & 74 & 5a $10 \mathrm{~m}$ & 12 & 74 & 5a $5 \mathrm{~m}$ & 12 & 85 & 9a 3m \\
\hline 13 & 84 & 6a 3m & 13 & 74 & $5 a 8 m$ & 13 & 85 & 8a 4m \\
\hline 14 & 74 & 6a 3m & 14 & 74 & 5a $10 \mathrm{~m}$ & 14 & 75 & 6a $11 \mathrm{~m}$ \\
\hline 15 & 74 & 5a $8 \mathrm{~m}$ & & & & 15 & 85 & 6a $11 \mathrm{~m}$ \\
\hline \multicolumn{3}{|c|}{ Média de idade - 6a $\mathbf{6 m}$} & \multicolumn{3}{|c|}{ Média de idade - $\mathbf{6 a} \mathbf{7 m}$} & \multicolumn{3}{|c|}{ Média de idade - 7a 5m } \\
\hline
\end{tabular}

Quadro 1 - Distribuição dos dentes e idade dos pacientes no momento da realização das pulpotomias. 
A seleção da amostra foi mediada pela análise clínica e radiográfica dos dentes, seguindo os seguintes critérios:

- Primeiros ou segundos molares decíduos inferiores comprometidos por cárie profunda, sem qualquer sintomatologia

- Ausência de fístula ou abscesso

- Ausência radiográfica de reabsorção interna e externa de mais de 2/3 da raiz

- Ausência de lesão na região de furca e no periápice

- Possibilidade restauradora

Optamos por molares inferiores pela facilidade de visualização dos achados radiográficos, visto que molares decíduos superiores freqüentemente apresentam sobreposição de estruturas ósseas sobre o dente.

Os critérios de exclusão foram:

- Presença de patologias sistêmicas

- História de reação alérgica ao látex do isolamento absoluto

- História de reação alérgica ao anestésico local ou aos materiais usados na pulpotomia.

Os procedimentos clínicos e radiográficos foram realizados por 3 odontopediatras que já se encontravam familiarizados com a técnica, visto que participam de pesquisas padronizadas relacionadas ao tema. Todos os procedimentos foram executados na clínica de Odontopediatria da Faculdade de Odontologia de Bauru.

Cada responsável legal pela criança foi esclarecido quanto ao conteúdo da pesquisa obtendo-se por escrito o consentimento para a participação no estudo (Anexo 2). Os dentes foram randomicamente divididos por um sistema computadorizado (Programa Microsoft Excel) entre os 3 grupos:

GI - pulpotomia com formocresol de Buckley diluído a 1/5

GII - pulpotomia com hidróxido de cálcio PA

GIII - pulpotomia com hidróxido de cálcio PA, precedido de antiinflamatório (Otosporin ${ }^{\circledR}$ )

\subsection{Procedimentos clínicos}

Todo o instrumental utilizado nos procedimentos operatórios foi esterilizado em autoclave, bem como as compressas de gaze e bolinhas de algodão. Os passos da técnica clínica incluíram:- anestesia tópica, anestesia do nervo alveolar inferior com anestésico local 
Mepivacaína $^{1}$ a 3\%. Após realização do isolamento absoluto, a lesão de cárie foi removida com auxílio de curetas de dentina ${ }^{2}$. A abertura coronária, bem como a remoção do teto da câmara pulpar, foi realizada com ponta diamantada esférica ${ }^{3}$ (1014 - 1015) em alta rotação sob irrigação, sendo que a remoção da polpa coronária foi feita manualmente com curetas de dentina $^{4}$ estéreis adequadas para a pulpotomia.

Tomou-se o cuidado de não aplicar anestesia intra-pulpar. Após a remoção do teto da câmara pulpar e exame clínico direto, o tecido pulpar foi considerado macroscopicamente vital quando apresentava resistência ao corte, coloração vermelho-vivo e hemorragia suave que cessava entre 2 e 5 minutos após a remoção da polpa coronária. Em seguida, foram realizadas irrigações constantes com soro fisiológico, secagem com bolinhas de algodão estéril, hemostasia, aplicação do material capeador e do medicamento, de acordo com o grupo indicado.

Para o Grupo I, uma bolinha de algodão estéril umedecida com Formocresol de Buckley diluído a $1 / 5^{5}$, tomando-se o cuidado da remoção do excesso do material com uma gaze, foi depositada na câmara pulpar, levemente pressionada na entrada dos condutos radiculares, e então mantida por 5 minutos. Decorrido o tempo determinado, a bolinha de algodão foi removida para a observação da fixação do remanescente pulpar. Na ausência de sinal de sangramento, uma base de óxido de zinco $^{6}$ e eugenol ${ }^{7}$ (presa lenta), com aproximadamente 1 milímetro de espessura, foi acomodada na câmara pulpar.

Nos grupos II e III, os passos iniciais foram iguais, diferindo na colocação da base capeadora. No grupo II, com auxílio de um porta amálgama estéril, o pó do hidróxido de cálcio $\mathrm{PA}^{8}$ foi depositado, delicadamente, sobre o remanescente pulpar numa espessura de aproximadamente $1 \mathrm{~mm}$, de modo que cobrisse toda a embocadura da polpa radicular.

No Grupo III, foi colocada uma bolinha de algodão estéril umedecida com Otosporin ${ }^{\circledR}$ ${ }^{9}$, tomando-se o cuidado da remoção do excesso do material com uma gaze, foi depositada na câmara pulpar, levemente pressionada na entrada dos condutos radiculares, e então mantida por 5 minutos. Decorrido o tempo determinado, a bolinha de algodão foi removida e em

\footnotetext{
${ }^{1}$ Mepiadre 100 - DFL Indústria e Comércio S.A., Rio de Janeiro, RJ - Brasil

${ }^{2}$ SS White artigos dentários Ltda, Juiz de Fora, MG - Brasil

${ }^{3}$ KG Sorensen, SP, Brasil

${ }^{4}$ SS White artigos dentários Ltda, Juiz de Fora, MG, Brasil

${ }^{5}$ Biodinâmica química e farmacêutica Ltda, Ibiporã, PR - Brasil

${ }^{6}$ Iodontosul, Porto Alegre, RS - Brasil

${ }^{7}$ Biodinâmica química e farmacêutica Ltda, Ibiporã, PR - Brasil

${ }^{8}$ Biodinâmica química e farmacêutica Ltda, Ibiporã, PR - Brasil

${ }^{9}$ Farmoquímica S/A Rio de Janeiro, RJ - Brasil
} 
seguida com auxílio de um porta amálgama estéril, o pó do hidróxido de cálcio $\mathrm{PA}^{8}$ foi depositado, delicadamente, sobre o remanescente pulpar numa espessura de aproximadamente $1 \mathrm{~mm}$, de modo que cobrisse toda a embocadura da polpa radicular.

Para todos os grupos, uma base de óxido de zinco e eugenol (presa rápida- $\left.\operatorname{IRM}^{\circledR}\right)^{10}$, com aproximadamente $2 \mathrm{~mm}$ de espessura foi adaptada na câmara coronária e realizada a restauração definitiva com cimento de ionômero de vidro modificado por resina $\left(\text { Vitremer }^{\circledR}\right)^{11}$. Após a realização da pulpotomia, uma radiografia periapical foi realizada (pós-operatório imediato) e o paciente dispensado.

O fluxograma (Figura 1) ilustra a seqüência dos procedimentos clínicos da pulpotomia com FC diluído a 1/5, com Hidróxido de Cálcio PA e com hidróxido de cálcio PA, precedido de antiinflamatório (Otosporin ${ }^{\circledR}$ ).

\subsection{Análise clínica e radiográfica aos 3, 6 e 12 meses}

Os dentes pulpotomizados foram avaliados clínica e radiograficamente aos 3, 6 e 12 meses após o procedimento para análise da resposta pulpar frente aos diferentes materiais capeadores utilizados.

Todos os cuidados quanto aos riscos relacionados às tomadas radiográficas foram criteriosamente controlados através da utilização de avental e protetor de tireóide revestidos por borracha plumbífera, posicionadores infantis para execução da técnica radiográfica e filme radiográfico ultra-rápido, possibilitando um baixo tempo de exposição às radiações.

As radiografias foram obtidas de forma padronizada, com o uso de posicionadores para técnica radiográfica periapical, do tipo Han-Shin, com distância foco/filme de aproximadamente $20 \mathrm{~cm}$ em aparelho de raios $\mathrm{X}$ odontológico com $70 \mathrm{kV}$ e $10 \mathrm{~mA}$, com tempos de exposição de 0,5 segundos. Foram utilizados filmes Insight de sensibilidade E-F da Marca $\operatorname{Kodak}^{12}$, tamanho $n^{\circ} 1$. A revelação das radiografias foi realizada utilizando-se processamento manual pelo método temperatura/tempo em soluções da Marca Exsil $\mathrm{Mx}^{13}$ (Silpa Chem - Fotoquímica) seguida de lavagem intermediária em tanque com água corrente por 20 segundos, fixação por 10 minutos, lavagem final em tanque com água corrente por 10

\footnotetext{
${ }^{10}$ Dentisply Indústria e Comércio Ltda, Petrópolis, RJ - Brasil

11 3M ESPE AG Dental Products, Saint Paul, MN, USA.

12 Kodak IP-01 Insight Infantil

${ }^{13}$ Fotoquímica
} 
minutos e posterior secagem das radiografias em meio ambiente, permitindo assim que a imagem final fosse obtida com controle de qualidade da imagem.

Foi considerado sucesso clínico aqueles dentes com ausência de dor, abscesso/fístula, sensibilidade à percussão, odor fétido e mobilidade patológica. O sucesso radiográfico foi considerado quando da ausência de reabsorção radicular interna, reabsorção radicular externa patológica, radiolucidez na área de furca e destruição do osso inter-radicular.

Todos os dados coletados durante os exames clínico e radiográfico foram anotados em uma ficha de avaliação previamente elaborada para posterior análise dos resultados (Anexo 4).

Durante todo o período deste estudo, 2 avaliadores previamente calibrados (Kappa>0,8) realizaram as avaliações. Quando havia dúvidas, um consenso foi estabelecido.

\subsection{Análise estatística}

Após a coleta, os dados foram analisados estatisticamente pelo Teste Qui-quadrado seguido do Teste de comparação em 3 proporções. Durante todo o período deste estudo, 2 avaliadores previamente calibrados (Kappa>0,8) realizaram as avaliações. Quando havia dúvidas, um consenso foi estabelecido. 



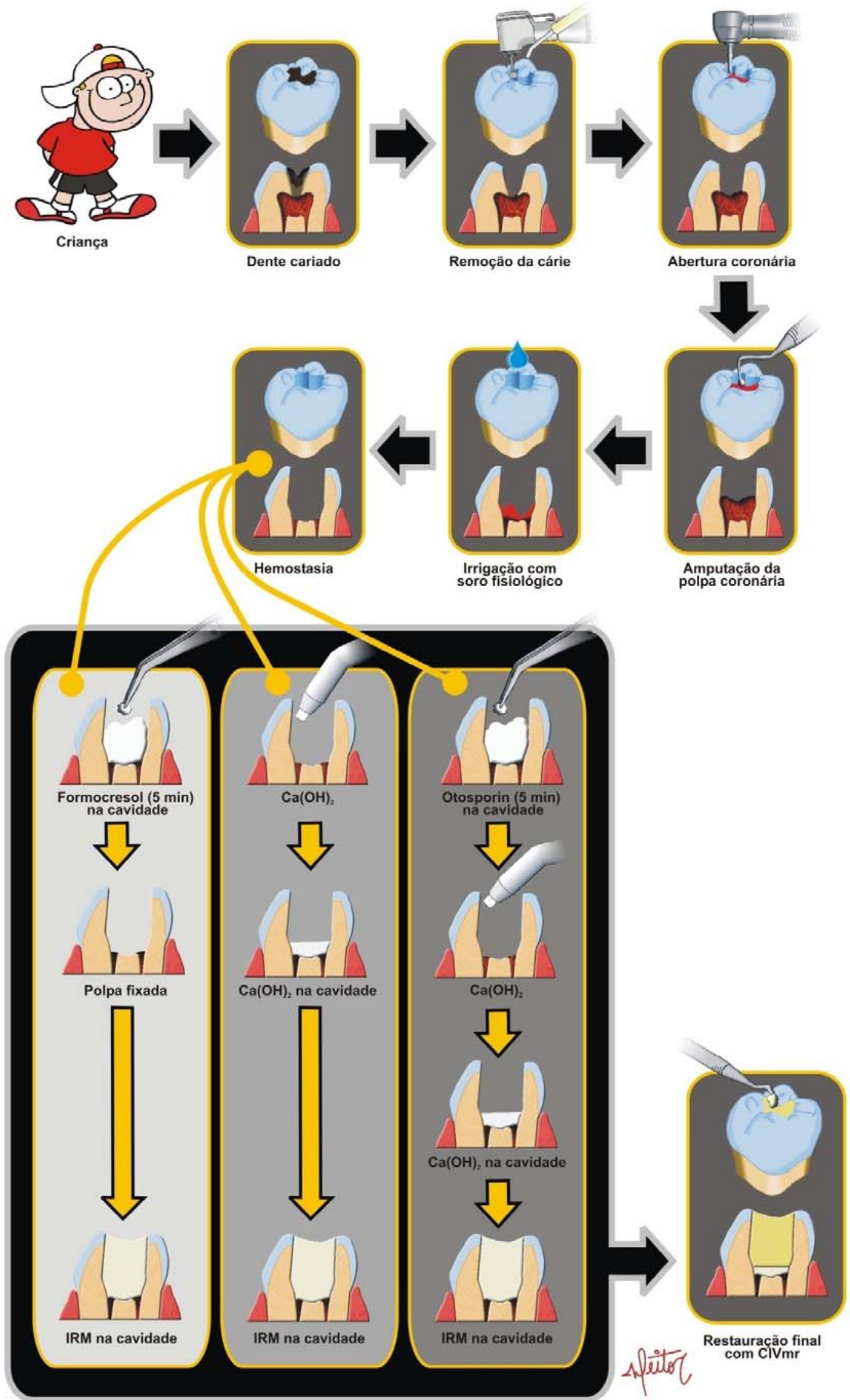

Figura 1 - Fluxograma com a seqüência de procedimentos clínicos realizados. 


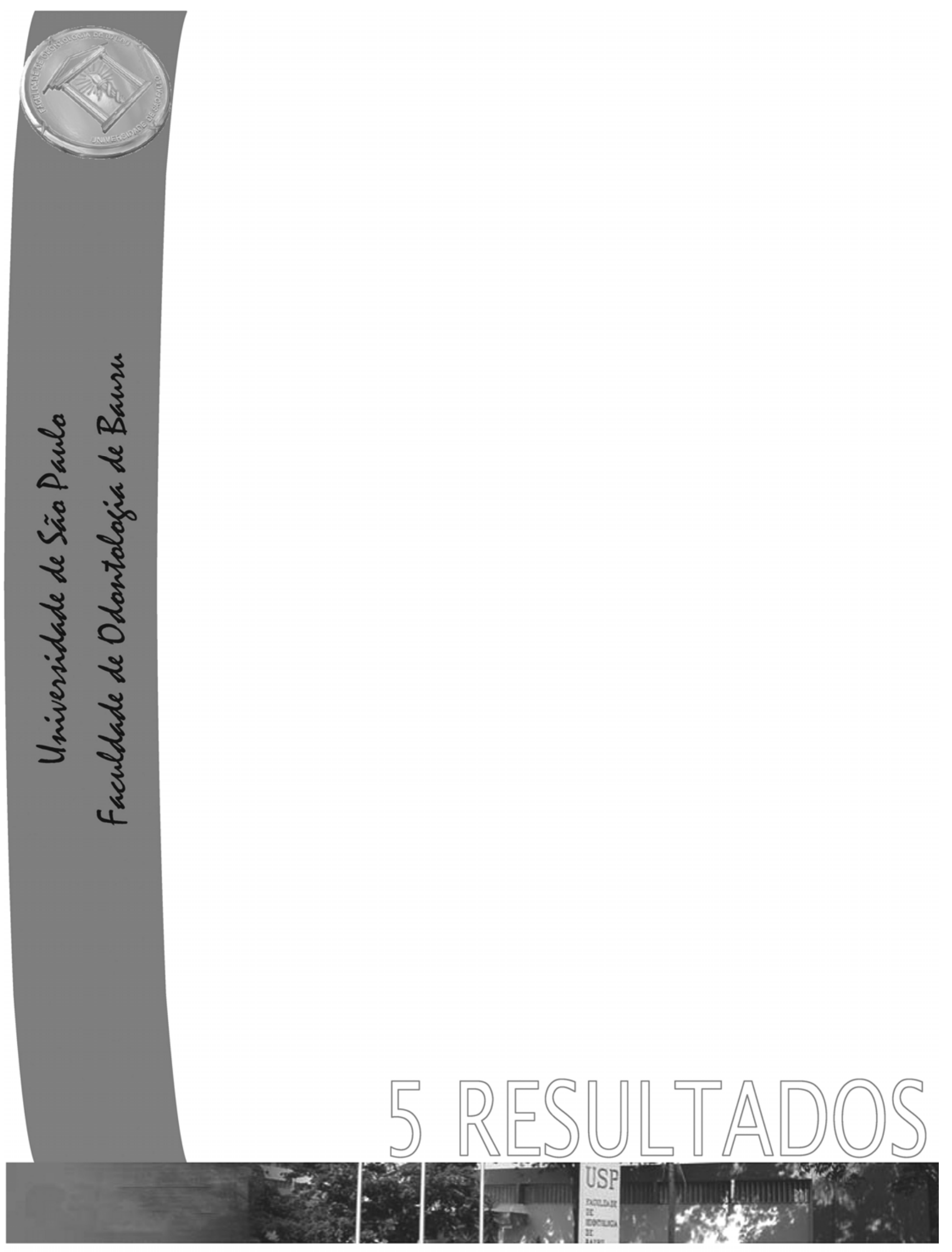




\section{RESULTTAOS}

Neste estudo, foram realizadas 45 pulpotomias em dentes decíduos de 35 crianças de 5 a 9 anos de idade - média de 6 anos e 6 meses, foram divididos entre os 3 grupos de tratamento (15 dentes por grupo) segundo o material aplicada na pulpotomia. Houve duas desistências aos 3 meses, uma para o grupo hidróxido de cálcio, onde a criança mudou-se de cidade, e outra no grupo hidróxido de cálcio precedido de antiinflamatório, onde a criança desistiu porque conseguiu tratamento na escola em que estudava. Ao final obtivemos 43 dentes avaliados clínica e radiograficamente nos períodos de 3, 6 e 12 meses.

No grupo Formocresol, $100 \%$ dos dentes tratados foram avaliados como sucesso clínico e radiográfico em todas as avaliações. Nenhum dente mostrou sinais de mobilidade, fístula, inflamação ou inchaço nos tecidos gengivais ao redor do dente pulpotomizado.

No grupo Hidróxido de cálcio, foi detectada radiograficamente reabsorção interna em 37,5\% (5 dentes) da amostra aos 3 meses de proservação. Na avaliação de 6 meses mais um caso de insucesso radiográfico, totalizando 42,9\% (6 dentes). Destes 6 casos, 2 dentes apresentaram também sinais clínicos de fracasso do tratamento, tais como: lesão na área interradicular, dor, mobilidade e abscesso, e foram extraídos.

No grupo Hidróxido de cálcio precedido de antiinflamatório (Otosporin ${ }^{\circledR}$ ), observamos radiograficamente 14,3\% (2 dentes) 3 meses após a realização das pulpotomias. No controle radiográfico de 6 meses detectamos 3 novos casos de reabsorção interna, totalizando 35,7\% (5 dentes). Destes 5 casos, 2 dentes esfoliaram naturalmente quando do controle de 12 meses, e nenhum dos dentes que apresentaram falha radiográfica apresentaram falhas clínicas, apenas um dente aos 6 meses apresentou ligeira mobilidade. 


\section{5 molares decíduos inferiores foram randomicamente divididos entre os 3 grupos}

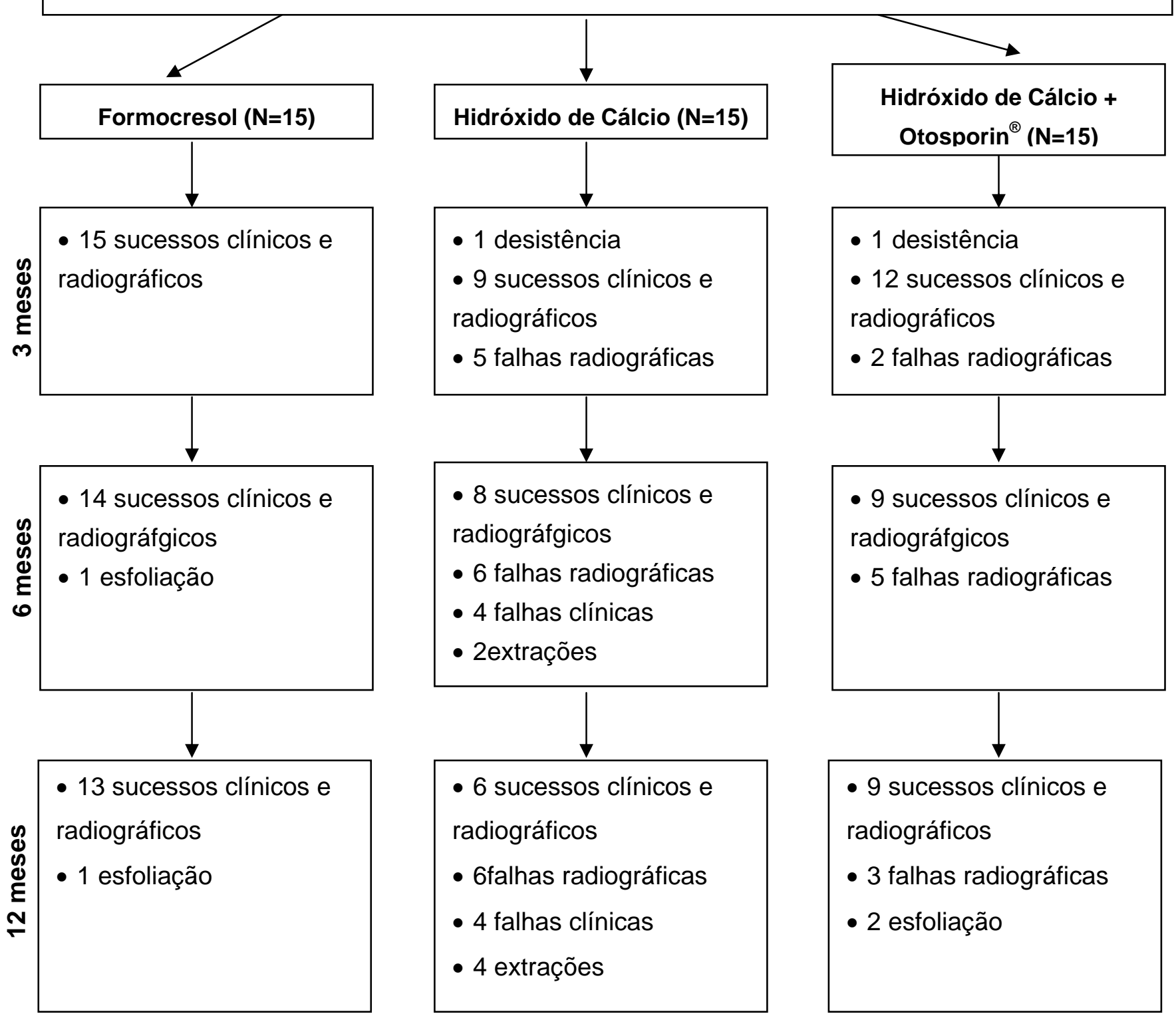

Figura 2 - Fluxograma dos pacientes e dentes pulpotomizados até 12 meses. 


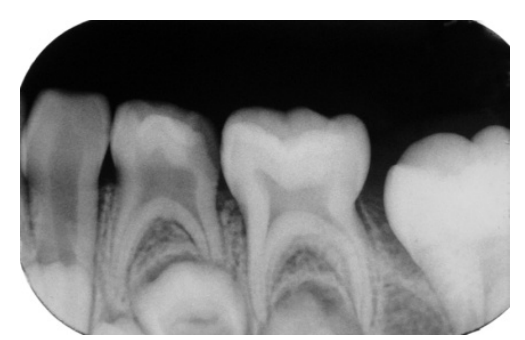

A

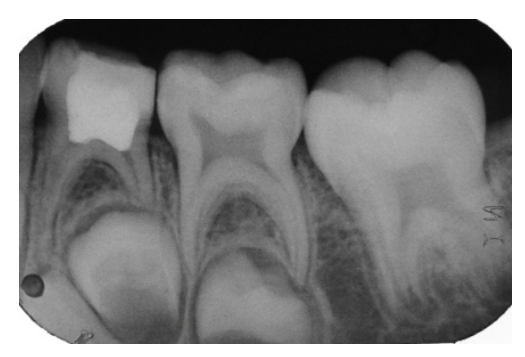

C

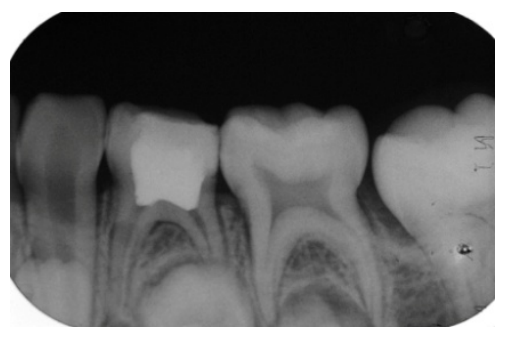

B

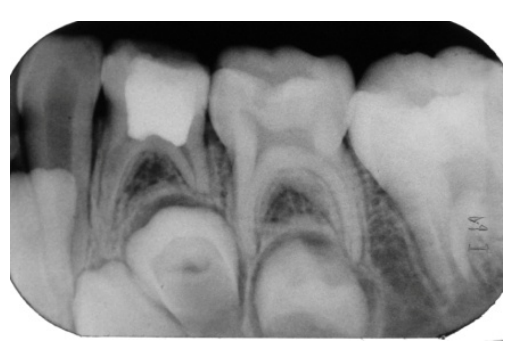

D

Figura 3 - Pulpotomia do dente 84 com Formocresol (sucesso radiográfico)
A - Radiografia inicial
B - Radiografia pós-operatório 3 meses
C - Radiografia pós-operatório 6 meses
D - Radiografia pós-operatório 12 meses 



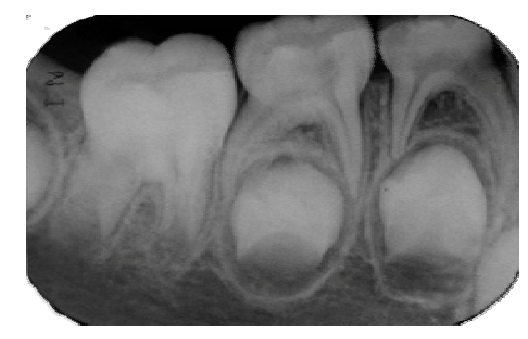

A

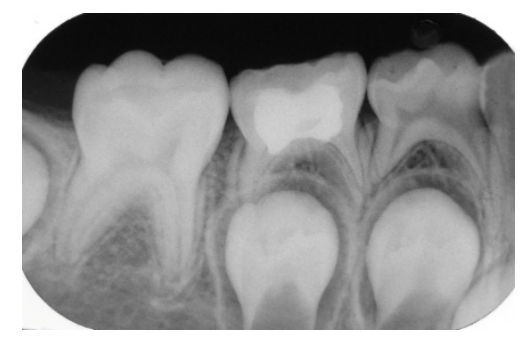

C

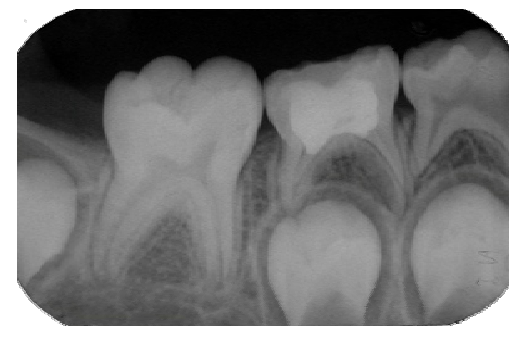

B

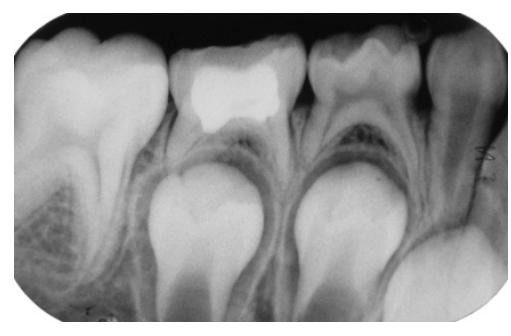

D

Figura 4 - Pulpotomia do dente 75 com Formocresol (sucesso radiográfico)
A - Radiografia inicial
B - Radiografia pós-operatório 3 meses
C - Radiografia pós-operatório 6 meses
D - Radiografia pós-operatório 12 meses 



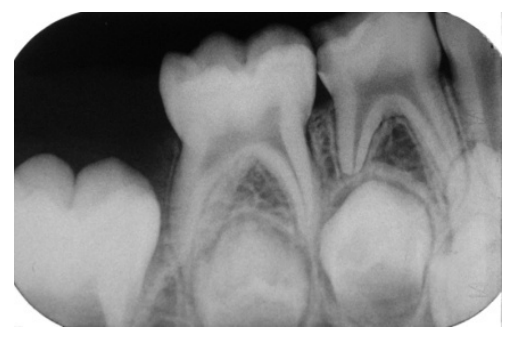

A

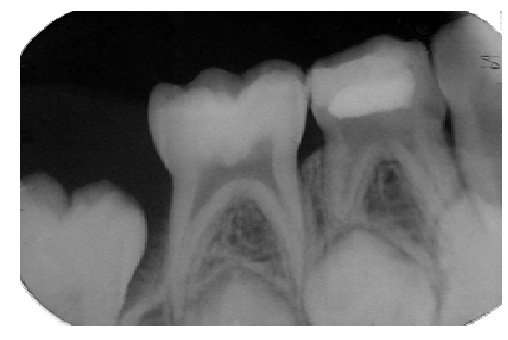

C

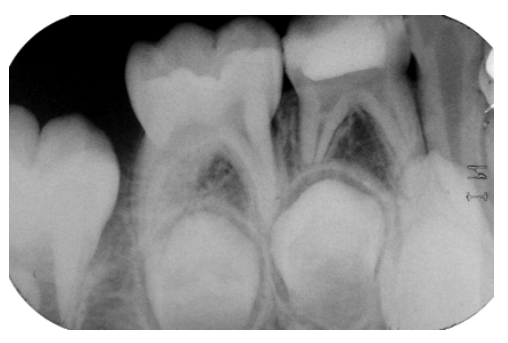

B

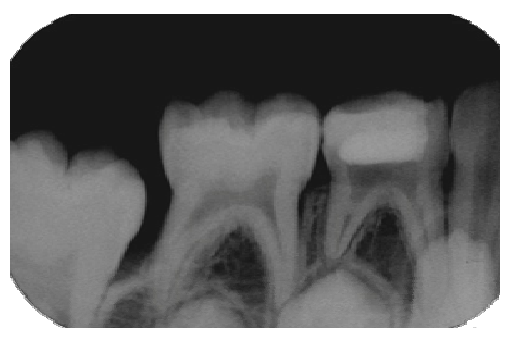

D

Figura 5 - Pulpotomia do dente 74 com Hidróxido de cálcio (sucesso radiográfico)
A - Radiografia inicial
B - Radiografia pós-operatório 3 meses
C - Radiografia pós-operatório 6 meses
D - Radiografia pós-operatório 12 meses 



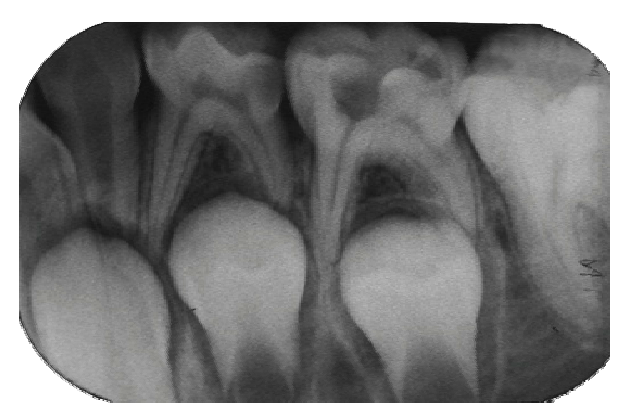

A

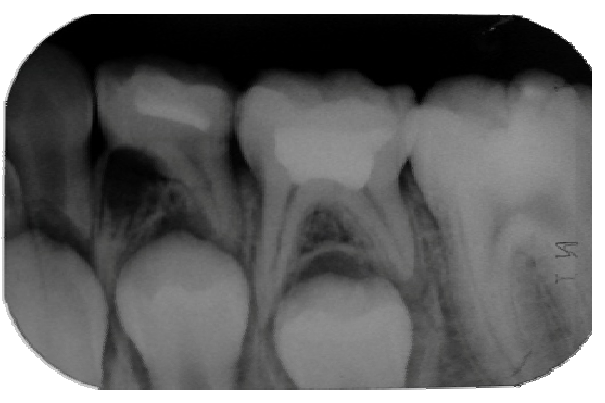

B

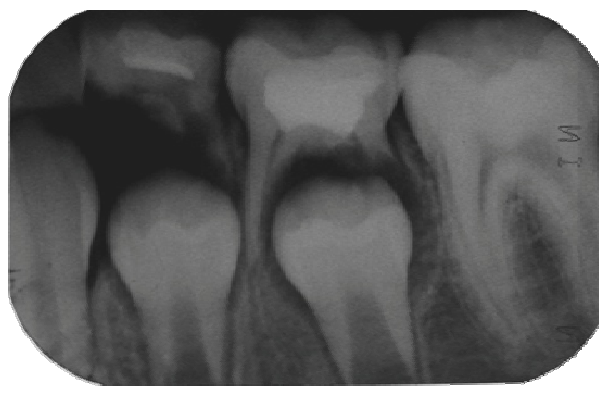

C

Figura 6 - Pulpotomia do dente 84 com Hidróxido de cálcio (insucesso radiográfico) Pulpotomia do dente 85 com Formocresol (sucesso radiográfico)
A - Radiografia inicial
B - Radiografia pós-operatório 3 meses
C - Radiografia pós-operatório 6 meses 



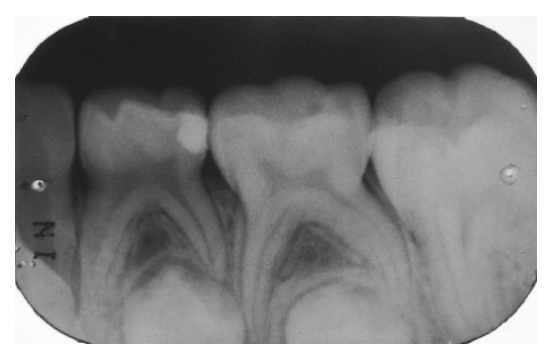

A

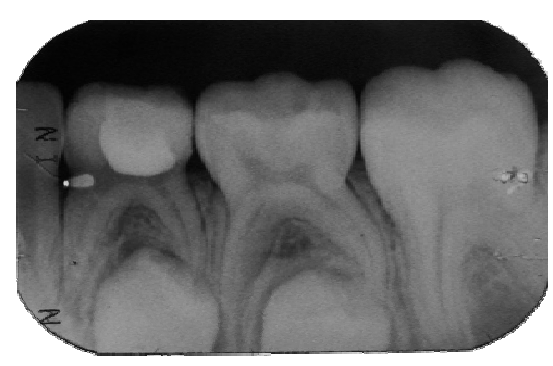

C

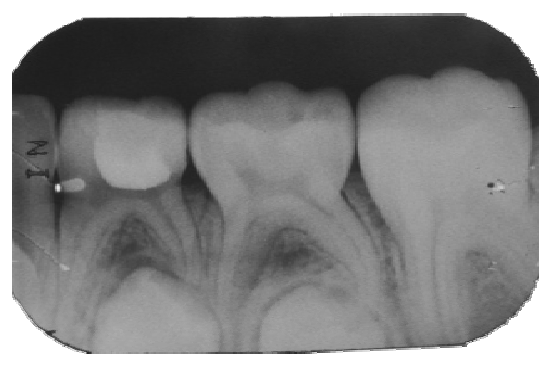

B

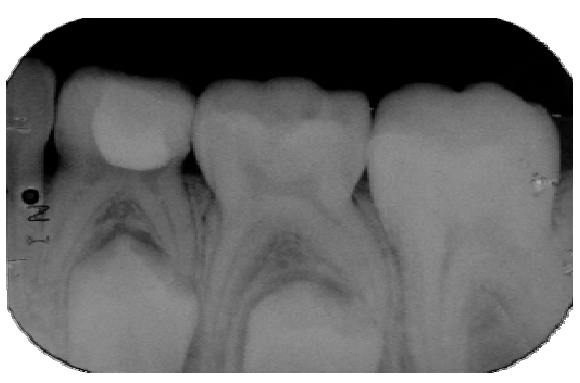

D

Figura 7 - Pulpotomia do dente 74 com Hidróxido de cálcio precedido de antiinflamatório - Otosporin ${ }^{\circledR}$ (sucesso radiográfico)
A - Radiografia inicial
B - Radiografia pós-operatório 3 meses
C - Radiografia pós-operatório 6 meses
D - Radiografia pós-operatório 12 meses 



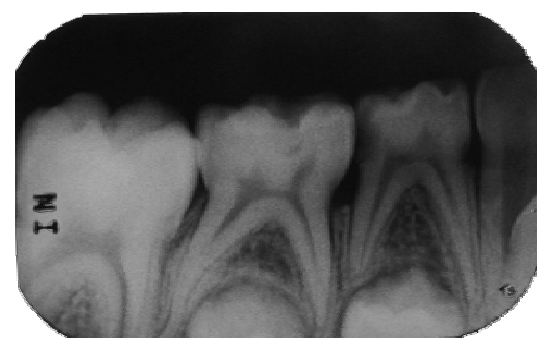

A

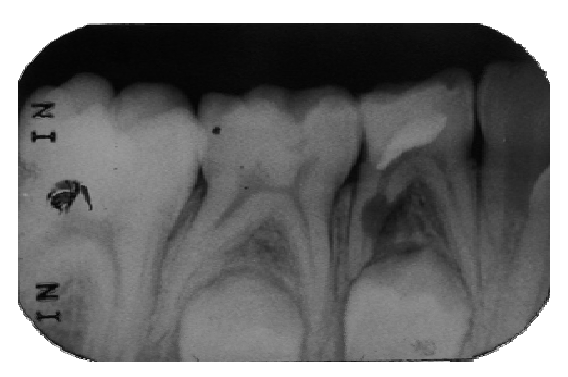

C

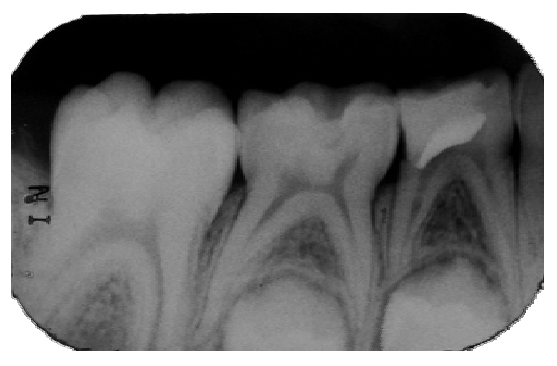

B

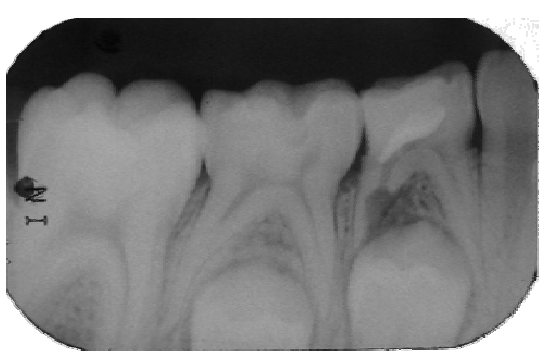

D

Figura 8 - Pulpotomia do dente 84 com Hidróxido de cálcio precedido de antiinflamatório - Otosporin ${ }^{\circledR}$ (insucesso radiográfico)
A - Radiografia inicial
B - Radiografia pós-operatório 3 meses
C - Radiografia pós-operatório 6 meses
D - Radiografia pós-operatório 12 meses 

Tabela 1 - Porcentagem de sucesso (S) e falha (F), observados clínica e radiograficamente para os grupos Formocresol, Hidróxido de cálcio e Hidróxido de cálcio precedido de antiinflamatório $\left(\right.$ Otosporin $^{\circledR}$ ), aos 3, 6 e 12 meses.

\begin{tabular}{lllllll} 
Tratamento & \multicolumn{3}{c}{ 3meses } & 6meses & 12meses \\
& $\mathrm{S}$ & $\mathrm{F}$ & $\mathrm{S}$ & $\mathrm{F}$ & $\mathrm{S}$ & $\mathrm{F}$ \\
\hline Grupo FC & 15 & 0 & 15 & 0 & 15 & 0 \\
\hline & $(100 \%)$ & & $(100 \%)$ & & $(100 \%)$ & \\
Grupo HC & 9 & 5 & 8 & 6 & 6 & 8 \\
\hline & $(64,3 \%)$ & $(35,7 \%)$ & $(57,1 \%)$ & $(42,9 \%)$ & $(42,9 \%)$ & $(57,1 \%)$ \\
Grupo HC + & $(12$ & 2 & 9 & 5 & 9 & $3 *$ \\
Otosporin ${ }^{*}$ & $(85,7 \%)$ & $(14,3 \%)$ & $(64,3 \%)$ & $(35,7 \%)$ & $(64,3 \%)$ & $(21,4 \%)$ \\
\hline
\end{tabular}

Comparando-se os três grupos estudados, apenas o grupo Formocresol apresentou diferença estatísticamente significante com relação aos demais grupos por ter apresentado 100\% de sucesso em todos os períodos de proservação.

Tabela 2 - Média geral de sucesso e insucesso dos medicamentos.

\begin{tabular}{ccc} 
& SUCESSO & INSUCESSO \\
\hline Grupo FC & $100 \%$ & 0 \\
\hline Grupo HC & $54,7 \%$ & $45,2 \%$ \\
\hline Grupo HC + & $71,4 \%$ & $23,8 \%$ \\
Otosporin ${ }^{\circledR}$ & & \\
\hline
\end{tabular}

A tabela das médias nos mostra um maior índice de sucesso das pulpotomias quando do uso do antiinflamatório (Otosporin ${ }^{\circledR}$ ) precedendo o Hidróxido de cálcio.

Com relação à reabsorção interna, uma diferença estatisticamente significativa foi observada quando comparado o grupo Hidróxido de cálcio com o grupo Formocresol ao longo dos meses estudados. Com relação à comparação do grupo Hidróxido de cálcio precedido de antiinflamatório (Otosporin ${ }^{\circledR}$ ) com o grupo Formocresol observou-se diferença estatisticamente significativa apenas no controle de 6 meses. Aos 12 meses de proservação devido às esfoliações naturais tidas como sucesso, esses grupos voltam a apresentar-se estatisticamente insignificantes. Quando da comparação entre os grupos Hidróxido de cálcio e Hidróxido de cálcio precedido de antiinflamatório (Otosporin®) não existe diferença estatisticamente significativa entre estes ao longo dos meses de controle (Tabela 3 , $p<0,05$ ). 
Tabela 3 - Reabsorção interna observada radiograficamente para pulpotomias com Formocresol, Hidróxido de cálcio e Hidróxido de cálcio precedido de antiinflamatório $\left(\right.$ Otosporin $^{\circledR}$ ), aos 3, 6 e 12 meses de acompanhamento.

\begin{tabular}{cccc} 
GRUPO & $\mathbf{3}$ meses & $\mathbf{6}$ meses & $\mathbf{1 2}$ meses \\
FC & 0 & 0 & 0 \\
\hline HC & $5^{\dagger}$ & $6^{\dagger}$ & $6^{\dagger}$ \\
\hline HC + Otosporin $\AA$ & 2 & $5^{\dagger}$ & 3 \\
\hline
\end{tabular}

${ }^{\dagger}$ Diferença estatisticamente significativa $(p<0,05)$

As tabelas 4, 5 e 6 mostram as falhas com relação à lesão na região de furca, mobilidade e fistula/abscesso, respectivamente, detectadas clínica e radiograficamente para os dentes tratados nos 3 grupos.

Tabela 4 - Lesão de furca observada radiograficamente para pulpotomias com Formocresol, Hidróxido de cálcio e Hidróxido de cálcio precedido de antiinflamatório (Otosporin ${ }^{\circledR}$ ), aos 3, 6 e 12 meses de acompanhamento.

\begin{tabular}{cccc} 
GRUPO & $\mathbf{3}$ meses & $\mathbf{6}$ meses & $\mathbf{1 2}$ meses \\
FC & 0 & 0 & 0 \\
\hline HC & 0 & 3 & 4 \\
\hline HC + Otosporin $\AA$ & 1 & 1 & 1 \\
\hline
\end{tabular}

${ }^{\dagger}$ Diferença estatisticamente significativa $(p<0,05)$

Tabela 5 - Mobilidade observada clinicamente para pulpotomias com Formocresol, Hidróxido de cálcio e Hidróxido de cálcio precedido de antiinflamatório (Otosporin ${ }^{\circledR}$ ), aos 3, 6 e 12 meses de acompanhamento.

\begin{tabular}{cccc} 
GRUPO & $\mathbf{3}$ meses & $\mathbf{6}$ meses & $\mathbf{1 2}$ meses \\
FC & 0 & 0 & 0 \\
\hline HC & 0 & 2 & 4 \\
\hline HC + Otosporin ${ }^{2}$ & 0 & 1 & 1
\end{tabular}

${ }^{\dagger}$ Diferença estatisticamente significativa $(p<0,05)$

Tabela 6 - Fistula/abscesso observados clinicamente para pulpotomias com Formocresol, Hidróxido de cálcio e Hidróxido de cálcio precedido de antiinflamatório (Otosporin ${ }^{\circledR}$ ), aos 3, 6 e 12 meses de acompanhamento.

\begin{tabular}{cccc} 
GRUPO & $\mathbf{3}$ meses & $\mathbf{6}$ meses & $\mathbf{1 2}$ meses \\
\hline FC & 0 & 0 & 0 \\
\hline HC & 0 & 2 & 4 \\
\hline HC + Otosporin ${ }^{\circ}$ & 0 & 0 & 0 \\
\hline
\end{tabular}

${ }^{\dagger}$ Diferença estatisticamente significativa $(p<0,05)$ 
Para o quesito formação de barreira dentinária, nenhuma formação de barreira foi observada no grupo Formocresol durante os períodos de estudo, fazendo com que houvesse uma diferença estatisticamente significante quando comparado com os outros dois grupos do estudo. Os grupos Hidróxido de cálcio e Hidróxido de cálcio precedido de antiinflamatório $\left(\right.$ Otosporin $^{\circledR}$ ) já apresentaram formação de barreira dentinária logo aos 3 meses de proservação, sendo que na comparação direta entre os grupos não houve diferença diretamente significante (Tabela 7, $\mathrm{p}<0,05$ ).

Tabela 7 - Barreira dentinária observada radiograficamente para pulpotomias com Formocresol, Hidróxido de cálcio e Hidróxido de cálcio precedido de antiinflamatório $\left(\right.$ Otosporin ${ }^{\circledR}$ ), aos 3, 6 e 12 meses de acompanhamento.

\begin{tabular}{cccc} 
GRUPO & $\mathbf{3}$ meses & $\mathbf{6}$ meses & $\mathbf{1 2}$ meses \\
FC & 0 & 0 & 0 \\
\hline HC & 3 & $7^{\dagger}$ & $6^{\dagger}$ \\
\hline HC + Otosporin ${ }^{\dagger}$ & 3 & $4^{\dagger}$ & $4^{\dagger}$ \\
\hline
\end{tabular}

${ }^{\dagger}$ Diferença estatisticamente significativa $(p<0,05)$ 


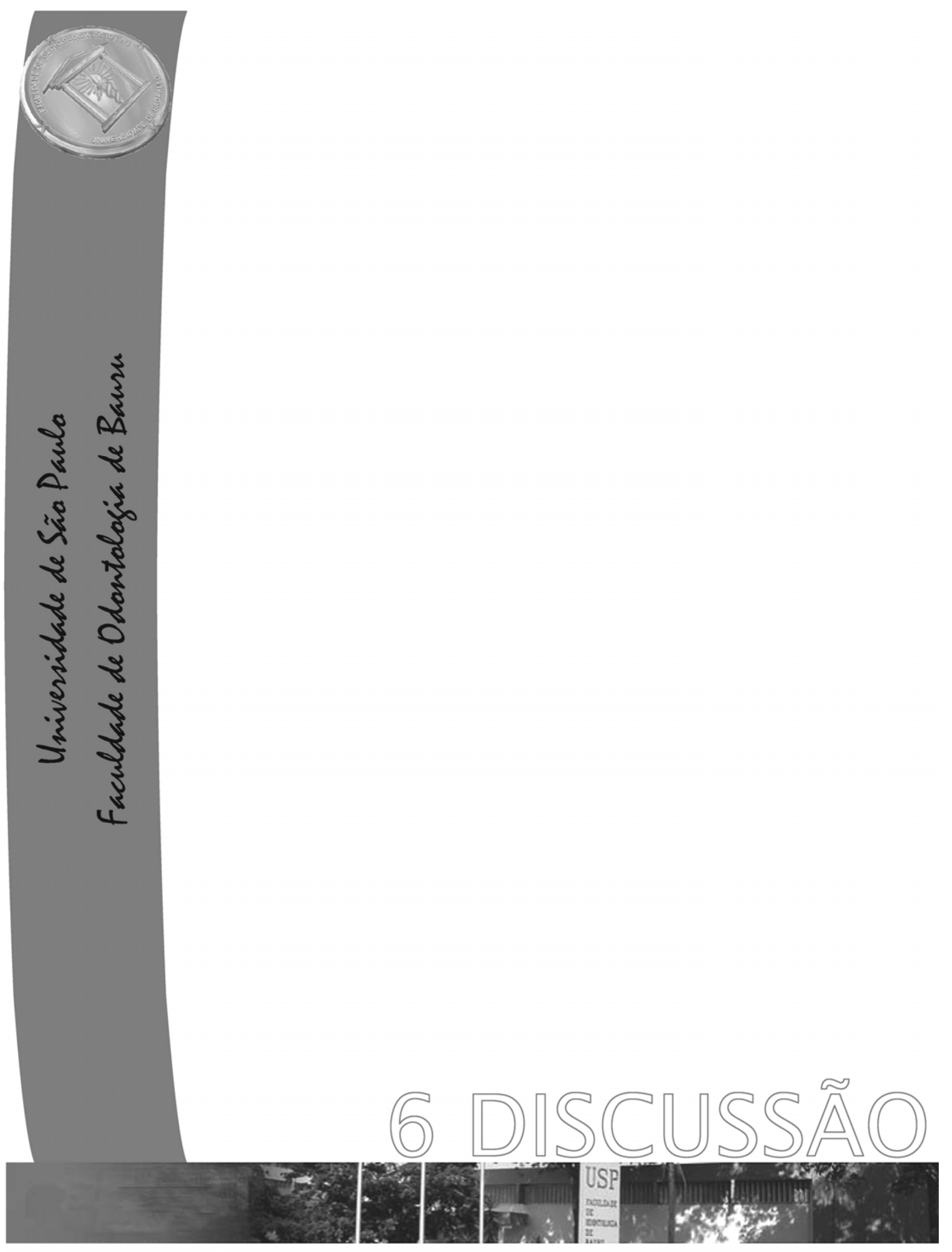




\section{6 ФISCUऽऽส̃ก}

A pulpotomia em dentes decíduos tem sido amplamente aplicada, como uma técnica conservadora de terapia pulpar, e também muito discutida nas ultimas décadas (HUNTER, HUNTER 2003; ARAÚJO et al. 2004). Este procedimento baseia-se no princípio de que a polpa radicular saudável é capaz de cicatrização após sua amputação cirúrgica na porção coronária. A finalidade da amputação da polpa coronária inflamada e o selamento dos remanescentes pulpares é permitir que o ciclo biológico de reabsorção radicular se processe naturalmente nos dentes decíduos (KRAMER, FARACO JUNIOR, FELDENS 2000; FARSI et al. 2005)

Quando bem indicada, esta técnica pode evitar entre outros transtornos o tratamento endodôntico radical e a perda prematura do dente decíduo, dessa forma auxilia na manutenção da vitalidade do elemento dentário e a preservação de suas funções (FERNANDES et al. 2003; SAYÃO-MAIA, RIBEIRO, MARCHIORI 2004; CASTRO 2005).

Alguns fatores como a presença de edema, fístula, mobilidade patológica, reabsorção interna, reabsorção externa de mais de $2 / 3$ da raiz, radiolucidez na região de furca e sangramento excessivo do coto pulpar radicular após a amputação da polpa radicular podem contra-indicar que o procedimento da pulpotomia seja aplicado nesses casos. Ainda podemos somar a estes a presença de dor espontânea ou noturna e sensibilidade a percussão como outros sinais que contra-indicam a realização da pulpotomia.

O procedimento de pulpotomia está indicado em dentes decíduos com ou sem exposição pulpar e lesões de cárie profunda de dentina (ARAÚJO et al. 2004; PENG et al 2006). O sucesso da técnica é determinado por uma cadeia de procedimentos, que vão desde o correto diagnóstico da condição pulpar, realização da técnica corretamente, até o tratamento restaurador e proservação.

Considera-se um fator muito importante para o sucesso da pulpotomia, a biocompatibilidade dos materiais utilizados, a assepsia do campo operatório, a execução com técnicas atraumáticas, além do correto diagnóstico da condição pulpar. Esta analise é de fundamental importância, principalmente quando do emprego de materiais regeneradores, pois o reparo depende da polpa apresentar-se em boas condições (WATERHOUSE, NUNN, WITHWORTH 2000; CHIBINSKI e CZLUSNIAK 2005).

Entretanto o correto diagnóstico da condição pulpar torna-se um desafio para o cirurgião dentista, principalmente pela dificuldade em se estabelecer com precisão a extensão 
do processo inflamatório instalado na polpa devido à cárie, e as possibilidades de reparação do tecido pulpar (ESTRELA et al. 1996; GUELMANN et al. 2002), tendo sempre em mente que nem sempre o diagnóstico clínico revela com exatidão o real estado histopatológico da polpa dentária (ESTRELA et al. 1996; MENEZES 2003).

É importante também lembrar que os dentes decíduos apresentam um ciclo vital característico, e este pode ser dividido em: rizogênese incompleta, rizogênese completa e rizólise. Em cada uma destas etapas o dente sofre intensas variações morfológicas e metabólicas (ARAÚJO 1982). Com relação à polpa dos dentes decíduos, durante o processo de rizólise, esta não apresenta alterações significantes em suas características estruturais e fisiológicas, do início até a metade da reabsorção radicular (CONSOLARO 2005). Vale salientar que após 2/3 de rizólise, ou seja, no estágio final de reabsorção do dente, nenhum tratamento endodôntico deve ser efetuado, incluindo a pulpotomia (ASSED 2005).

Nesta pesquisa os dentes foram criteriosamente selecionados segundo critérios clínicos e radiográficos previamente estabelecidos (PASTOR et al. 1986; EIDELMAN, HOLAN, FUKS 2001). O diagnóstico da condição pulpar seguiu critérios rigorosos como a avaliação minúciosa dos dados da anamnese e do exame radiográfico, somado a uma cuidadosa avaliação do tecido conjuntivo pulpar durante a exposição e curetagem da polpa coronária. Realizada a abertura coronária, a polpa foi macroscopicamente avaliada e considerada vital e favorável ao procedimento, quando apresentou-se com uma coloração vermelho vivo, resistência ao corte e uma suave hemorragia, onde a hemostasia foi facilmente alcançada em até 5 minutos (MASSARA et al. 1996; RALSTRON 1999; FUKS 2000; ROCHA et al. 2000; EIDELMAN, HOLAN, FUKS 2001; ARAÚJO et al. 2004; CASTRO 2005).

O controle da hemorragia pulpar após o seu corte na técnica da pulpotomia é considerado uma variável significante nos resultados da pulpotomia (WATERHOUSE, NUNN, WITHWORTH 2000; TUNÇ et al. 2006). Levando em consideração este fato, para todos os grupos deste estudo, foi tomado cuidado com relação ao controle da hemorragia, assim como para que não houvesse coágulo sanguíneo entre o remanescente pulpar e o material capeador empregado.

Nenhuma anestesia intrapulpar foi realizada nesta pesquisa visando minimizar sintomatologia dolorosa ou conter a hemorragia, uma vez que a quantidade e a qualidade do sangramento foi um indicador clínico do estado da polpa radicular. Portanto pode ser descartada a possibilidade de qualquer associação entre a ocorrência de alterações e falhas no diagnóstico para os 3 grupos estudados. 
Mesmo sendo uma técnica há bastante tempo empregada na Odontologia, a pulpotomia de dentes decíduos ainda causa muitos questionamentos e discussões, principalmente nos dias de hoje, onde a tendência das pesquisas odontológicas está voltada para a busca de técnicas e tratamentos que favoreçam as reações de defesa do organismo, assim como a busca por medicamentos mais biocompatíves para serem empregados, visando manter a polpa radicular vital e em plenas condições funcionais (AGAMY et al. 2004; AEINEHCHI et al. 2007; MORETTI et. al 2008).

Esta pesquisa avaliou por meio de avaliações clínicas e radiográficas, nos períodos de 3, 6 e 12 meses, a resposta pulpar de 45 dentes decíduos humanos submetidos à pulpotomia, utilizando-se três agentes capeadores: Formocresol (FC) de Buckley diluído a 1/5; Hidróxido de cálcio PA; Hidróxido de cálcio PA precedido de antiinflamatório (Otosporin ${ }^{\circledR}$ ).

No presente estudo 15 dentes foram tratados pela técnica da pulpotomia com formocresol de Buckley diluído a 1/5 como agente capeador, o mesmo foi selecionado como grupo controle por ser ainda hoje considerado um agente terapêutico padrão ouro ("gold standard”) em estudos envolvendo pulpotomias de dentes decíduos (WATERHOUSE 1995; EIDELMAN, HOLAN, FUKS 2001; AGAMY et al. 2004; NAIK e HEDGE 2005; HOLAN, EIDELMAN, FUKS 2005; NEAMATOLLAHI e TAJIK 2006; KAAREN 2006; PERCINOTO et al. 2006).

Mesmo com todas as adversidades que existem à respeito da utilização do formocresol, muitas pesquisas comprovam que a técnica da pulpotomia com o uso deste agente capeador é bastante empregada pela grande maioria dos odontopediatras (KING, McWHORTER, SEALE, 2001; HUNTER e HUNTER, 2003). Na revisão de literatura realizada por Avram e Pulver (1989), pode-se constatar que 76\% das escolas de Odontologia do mundo preconizam o uso do formocresol em pulpotomias de dentes decíduos. Em nosso país 63\% das instituições de ensino de Odontologia indicam a utilização do formocresol em dentes decíduos, havendo uma preferência pela fórmula diluída a 1/5 (KRAMER, FARACO JÚNIOR, FELDENS, 2000), assim como no serviço público, devido ao seu baixo custo.

Em nosso estudo optamos pelo emprego do formocresol diluído a 1/5 pois vários estudos como o de Morawa (1975), Abdo (1976), Abdo et al. (1981), Vono et al. (1991), Burnett e Walker (2002) e Rivera et al. (2003) comprovaram que a solução de FC diluída a 1/5 é tão efetiva quanto a concentrada original, possuindo as mesmas propriedades bactericidas e de fixação tecidual, com o diferencial de ser menos tóxica e agressiva aos tecidos pulpares e periapicais. 
Enquanto inúmeras pesquisas clínicas e radiográficas ainda fazem uso, com sucesso, do formocresol em pulpotomias de dentes decíduos (BENGTSON, GUEDES-PINTO, BENGTSON, 1986; VONO et al., 1991; FUKS et al., 1997a; FUKS et al., 1997b; WATERHOUSE, NUNN, WHITWORHT, 2000; IBRICEVIC, AL-JAME, 2000; DEAN et al., 2002; HUTH, et al., 2005), pois o mesmo apresenta capacidade de fixar e desvitalizar, aliviar a dor mesmo em polpa inflamada. Porém grande parte dos estudos microscópicos questiona sua utilização (ABDO, 1976; ABDO et al., 1981; SALAKO et al., 2003; AGAMY et al., 2004; MORETTI, 2008).

Pode-se dizer que embora o formocresol tenha propriedades bactericidas, também tem propriedades irritantes ao tecido pulpar. Este medicamento promove a fixação do tecido tornando-o, portanto, “fibrótico" (morto), e reconhecido pelo organismo como um corpo estranho. Os altos índices de sucesso alcançados com a técnica da pulpotomia utilizando formocresol podem, possivelmente esconder uma inflamação crônica silenciosa no remanescente pulpar radicular, o que mais tarde pode ocasionar algum tipo de insucesso (WATERHOUSE, NUNN, WHITWORTH, 2000; CHIBINSKI e CZLUSNIAK, 2003; AGAMY et al., 2004).

Mesmo com todas as pesquisas realizadas e os dados obtidos inúmeros países, incluindo o Brasil, ainda preconizam o uso do formocresol em suas faculdades de Odontologia. E mesmo pesquisas avaliando a toxicidade e potencial carcinogênico deste medicamento apresentam resultados controversos, alguns afirmam haver risco a saúde humana devido a absorção sistêmica (PASHLEY et al., 1980; RANLY, 1985), e outros relatam que a dose utilizada em pulpotomias é inofensiva ao organismo humano (LEWIS, 1998; MILNES, 2006). A observação histológica mais constante nos dentes tratados com formocresol é a permanência de um processo inflamatório na zona pulpar abaixo do tecido que entrou em contato com o fármaco, além da ausência de sinais de reparo, o que caracteriza o formocresol como um material não biológico (FAROOQ et al., 2000; KRAMER, FARACO JUNIOR; FELDENS, 2000; FERNANDES et al., 2003; MORETTI, 2008).

A Agência Internacional de Pesquisas sobre Câncer - IARC (2004) da Organização Mundial de Saúde determinou que o formaldeído causa câncer nasofaríngeo e reclassificou-o como um conhecido carcinogênico humano. Relatos de Hingston, Parmar e Hunter (2007) mostram que mesmo após a liberação do documento da IARC, dentistas da cidade de Wales (Inglaterra) continuaram utilizando o formocresol como medicamento de pulpotomia em dentes decíduos. Documentos da Sociedade Britânica de Odontopediatria foram divulgados em 2000 e 2003 com conteúdos que, segundo os autores, promovem um conflito entre os 
dentistas: enquanto o documento de 2000 defendia o uso do FC diluído a 1/5, o documento de 2003 acrescenta o sulfato férrico, o MTA e o hidróxido de cálcio como opções de tratamento.

Zarzar et al. (2003) investigou a mutagenicidade do formocresol de Buckley, na concentração original, em cultura de linfócitos obtidos do sangue de crianças com idades entre 5 a 10 anos que receberam pulpotomia com este medicamento, nas amostras analisadas o formocresol foi mutagênico para um paciente, levantando dúvidas sobre o emprego do medicamento em pulpotomias, em vista desses resultados os autores sugerem que mais pesquisas devam ser realizadas, principalmente em crianças que necessitem de mais de uma pulpotomia, uma vez que o aumento da quantidade da droga também aumentaria as aberrações cromossômicas.

Milnes (2006) relata a necessidade de maiores esclarecimentos em relação aos efeitos adversos do formocresol, antes que esse medicamento seja abandonado pela classe odontológica. O autor acrescenta que a quantidade de formocresol na fórmula diluída usada em pulpotomias é pequena e, portanto, não causa efeitos como toxicidade e mutagenicidade. Existe, portanto, a necessidade de se estabelecer um consenso na Odontologia com relação ao uso do formocresol.

A luz de todos esses fatos, muito ainda se discute e muito continua sendo pesquisado sobre os efeitos adversos do formocresol e sobre as taxas de sucesso e insucesso do mesmo clínica e radiograficamente. Os resultados encontrados por Pastor et al. (1896), Vono et al. (1991), Ibricevic, Al - Jame (2000), Dean et al. (2002), Rivera et al. (2003), Fernandes et al. (2003), Aeinehchi, et al. (2007), Fornetti (2007) e Moreti (2008), relatam o sucesso clínico e radiográfico do formocresol em pulpotomias quando da proservação de 12 meses, havendo uma tendência de que os índices de sucesso diminuam à medida que aumenta o tempo de proservação dos dentes tratados com FC (FAROOQ et al., 2000; FUKS, 2000; HOLAN, FUKS, KELTZ, 2002; AGAMY et al., 2004).

Neste estudo verificamos que todos os dentes tratados com FC apresentaram 100\% de sucesso clínico e radiográfico ao final do período estudado, que foi de 12 meses, o que é condizente com os estudos citados anteriormente.

Embora a literatura apresente resultados clínicos e radiográficoas de sucesso quando do uso do formocresol em pulpotomias de dentes decíduos, ainda permanece um dilema entre odontopediatras no mundo inteiro: usar ou não o formocresol como medicamento em pulpotomias de dentes decíduos (CORTÉS et al. 2007). Por isso torna-se imprescindível a busca por novos materiais que demonstrem além de um sucesso clínico e radiográfico idêntico 
ou superior ao formocresol, mas também um potencial biológico que favoreça o restabelecimento da saúde pulpar.

No segundo grupo de nosso estudo utilizamos o hidróxido de cálcio, sob a justificativa deste ser considerado um material biológico, bastante empregado na Odontologia, principalmente em dentes permanentes, devido às suas propriedades antibacterianas e biocompatibilidade (ACCORINET et al., 2008). Este agente capeador tem o potencial de manter a vitalidade do remanescente pulpar radicular, com formação de barreira de tecido mineralizado na região onde a polpa foi amputada, podendo ser aplicado diretamente sobre o remanescente pulpar, ocorrida a hemostasia (EIDELMAN, HOLAN, FUKS, 2001).

Ao ser aplicado sobre a polpa exposta, o HC, em decorrência do seu $\mathrm{pH}$ altamente alcalino, promove a formação de uma zona limitada de necrose por coagulação nas duas primeiras horas (ALCURE, 2001). A área de necrose limita-se à superfície da polpa e não impede os mecanismos de reparo, pelo contrário, atua como estímulo para a migração e a diferenciação celular, participando do mecanismo de reparo (ALCURE, 2001; DOMINGUEZ et al. 2003; CHACKO e KURIKOSE, 2006). Após esse período inicial, o tecido pulpar se reorganiza e uma nova camada de odontoblastos é formada.

Existem muitas controvérsias em relação ao seu uso em pulpotomias de dentes decíduos (RANLY, 1994; WATERHOUSE et., 2000; CAICEDO et al. 2006; TUNÇ et al., 2006; PERCINOTO et al., 2006). Este material que já foi considerado o preferido dentre os materiais regeneradores para pulpotomias em dentes decíduos, hoje apresenta uma limitada taxa de sucesso e alguns bons sucessores como o Agregado Trióxido Mineral (MTA) e o cimento Portland. Além disso, a pulpotomia com HC mostra ser uma técnica mais sensível, na qual a condição pulpar é um fator crucial quando comparado a outras técnicas de pulpotomia (HUTH et al., 2005).

O insucesso mais freqüente em nossa pesquisa, no grupo de dentes tratados com o hidróxido de cálcio, foi a falha radiográfica, caracterizada pela reabsorção interna, o que posteriormente levou a falha clínica. Na pesquisa realizada por Moretti (2008) os cortes microscópicos dos dentes tratados com hidróxido de cálcio, que apresentaram falhas ao tratamento revelaram presença de extensa necrose pulpar. Em alguns espécimes, havia presença de biofilme microbiano e células vegetais em toda extensão do canal radicular e câmara pulpar. Estes achados estão em concordância com os nossos achados clínicos e radiográficos dos referidos dentes. Sendo que a presença de biofilme microbiano e células vegetais indicam a contaminação do tecido pulpar por microrganismos e restos alimentares. 
Associou-se o insucesso da pulpotomia quando do uso de hidróxido de cálcio também devido à idade do paciente, ou seja, a rizólise seria fator decisivo para se determinar o uso do hidróxido de cálcio em dentes decíduos. No entanto, sabe-se que essa afirmação é errônea e pôde ser confirmada em nosso estudo. No grupo hidróxido de cálcio, crianças com idade entre 5 e 7 anos com dentes decíduos apresentando pouca reabsorção radicular fisiológica, mostraram insucesso clínico e radiográfico caracterizado por sensibilidade, abscesso, mobilidade e reabsorção interna. No entanto, no mesmo grupo, dentes com reabsorção radicular fisiológica entre 1/3 e 2/3 apresentaram sucesso clínico e radiográfico com formação de barreira de tecido mineralizado. A idade não foi fator de insucesso para os grupos estudados, independente da idade da criança, sucessos clínicos e radiográficos foram observados em todos os casos tratados e em todos os períodos de avaliação, dados em concordância com Ritwik et al. (2003).

Outro fator ao qual pode ser associada à reabsorção interna é o contato do hidróxido de cálcio com um coágulo (CURZON et al., 2000), mas em nosso estudo foi tomado um cuidado especial com relação ao controle da hemorragia para que não houvessem coágulos, porém não descartamos essa possibilidade já que uma incisão em tecido vital produz hemorragia e exsudação (WATERHOUSE et al., 2000b).

Ao final de nosso estudo a taxa de insucesso encontrada no grupo hidróxido de cálcio foi de 57,1\%, se assemelhando aos estudos de Gruythuysen e Weerheijm (1997), Waterhouse et al. (2000), Huth et al. (2005) e Sari, Sonmez e Cetinbas (2007) relatam taxas de insucesso para pulpotomias com hidróxido de cálcio de 20, 23, 47 e 53.85\% respectivamente. Este grupo apresentou 5 casos de reabsorção interna aos 3 meses e mais 1 aos 6 meses, os quais foram considerados fracassos.

Veja que a reabsorção interna confinada ao dente, sem alterações radiográficas no osso ao redor do dente envolvido e sem comprometimento do germe do sucessor permanente é considerado por Smith et al. (2000) apenas como insucesso radiográfico. Em nosso estudo, as reabsorções internas foram observadas no controle radiográfico de 3 meses de pós-operatório, sendo que na avaliação de 6 meses, as reabsorções haviam progredido muito, e os dentes apresentaram abscesso dento alveolar e mobilidade, necessitando de exodontia e colocação de mantenedor de espaço.

Estes achados estão de acordo com outros já relatados na literatura por Watherhouse, Nunn e Whitworth (2000); Vargas e Packham (2005). Estes autores confirmam que o fracasso da técnica leva a alterações patológicas no dente decíduo tratado tais como lesão periapical, 
lesão interradicular, presença de abscesso e/ou fístula, reabsorção interna, mobilidade e odor fétido, ocasionando a necessidade da exodontia precoce do elemento dentário.

Outro fator importante em relação ao hidróxido de cálcio é a sua relativa solubilidade, a dissolução deste material quando em contato com fluido intersticial introduzido via coroa, tecidos necróticos e até mesmo a respiração normal das células, pode ter prejudicado o potencial de reparo do mesmo, segundo Yates (1988) o hidróxido de cálcio é rapidamente absorvido durante os estágios iniciais de tratamento, sendo que essa taxa de absorção diminui à medida que a barreira é formada e devido essa dissolução do material houve pouco contato deste com o tecido pulpar. Em um segundo momento essa dissolução também pode ter permitido um contato mais íntimo com o eugenol da base de óxido de zinco e eugenol colocada sobre os materiais capeadores. É conhecido que o eugenol, quando em contato com tecidos vitais pode causar moderada à severa resposta inflamatória, resultando em inflamação crônica e necrose (GRUYTHUYSEN e SMITS, 1995; GRUYTHUYSEN, 1997). Independente do material capeador, uma sobre-base de óxido de zinco e eugenol é rotineiramente colocada sobre os materiais capeadores em pulpotomias de dentes decíduos.

A reabsorção interna pode ser atribuída à presença de grânulos ou partículas de hidróxido de cálcio que se desprendem do material capeador, iniciando uma resposta fagocitária na polpa radicular remanescente (HEILIG et al., 1984). Somado a isso ainda podemos citar alguns estudos microscópicos relatam número maior de reação inflamatória, hiperemia e necrose e menor freqüência de formação de barreira de tecido mineralizado para dentes que receberam pulpotomia com HC, além de reabsorção deste material, proporcionando infiltração de microrganismos (FADAVI e ANDERSON, 1996; FARACO JÚNIOR, e HOLLAND, 2001; AEINEHCHI et al., 2003; MORETTI, 2008).

Nos casos de insucesso das pulpotomias com hidróxido de cálcio observados no estudo de Moretti (2008), os cortes microscópicos revelaram presença de extensa necrose pulpar, podendo assim levantar a hipótese de que talvez a irritação ao tecido pulpar, levando a uma zona de necrose superficial, possa ter evoluído para uma necrose do restante do tecido pulpar remanescente, pelo fato da polpa sucumbir ao processo de reparo. A causa para a ocorrência de reabsorção interna de dentes decíduos tratados com a técnica de pulpotomia hidróxido de cálcio ainda não está bem esclarecida.

Em se tratando de um material biológico, o ideal quando da utilização do hidróxido de cálcio é manter a vitalidade do remanescente pulpar radicular com formação de barreira de tecido mineralizado na região onde a polpa foi amputada. Nesse pesquisa, para o grupo onde a pulpotomia foi realizada com hidróxido de cálcio, foi observada a formação de barreira 
dentinária em 3 dentes aos 3 meses de proservação e 4 novos casos de barreira aos 6 meses de pós-operatório, porém nenhuma nova barreira foi observada após este período. É importante ressaltar que são comuns os casos de barreira de tecido mineralizado não observadas radiograficamente, pois devido à incidência dos feixes de raios X e localização da barreira, essa pode ficar sobreposta a outras estruturas e não estar aparente no exame radiográfico, sendo possível sua confirmação somente através de microscopia, quando possível a exodontia do dente envolvido.

O conceito de barreira de tecido mineralizado é um assunto controverso no meio científico atual, uma vez que a presença de barreira pode ser vista como resposta de reparação ou como reação da polpa a uma irritação (DOMINGUEZ et al. 2003; CHACKO e KURIKOSE, 2006). Veja que somente a formação de barreira de tecido mineralizado não pode ser considerado indicativo de saúde pulpar (WATERHOUSE, NUNN e WHITWORTH, 2000; PARIROKH et al., 2005; CHACKO e KURIKOSE, 2006; CAICEDO et al., 2006), outros fatores como a presença ou ausência de inflamação pulpar, necrose, reabsorção interna, além dos indicativos do sucesso clínico como a ausência de mobilidade, fístula e odor fétido. Por fim é importante citar que a formação de barreira não indica que a polpa esteja totalmente selada do ambiente bucal (SCHUURS et al. 2000; WATERHOUSE et al., 2000; CHACKO e KURIKOSE, 2006). Waterhouse, Nunn e Whitworth (2000) observaram em radiografias pósextrações e em secções microscópicas, a presença de barreira de tecido mineralizado em dentes que apresentaram sinais clínicos de insucesso após pulpotomias com hidróxido de cálcio.

O hidróxido de cálcio forma barreira de tecido mineralizado quando colocado em contato com o tecido pulpar (RASMUSSEN e MJÖR, 1971; WITHERSPOON et al., 2006). Porém, sabe-se que o efeito inicial do hidróxido de cálcio sobre o tecido pulpar não é bom (BRISO et al., 2006), pois este material libera íons hidroxila causando inicialmente uma injúria ao tecido pulpar levando a uma necrose superficial. Uma barreira de tecido mineralizado pode ser formada contra esta zona de necrose, ou esta zona pode ser reabsorvida e substituída pela barreira (WITHERSPOON et al., 2006). No estudo de Moretti (2008) os cortes microscópicos revelaram a presença de extensa barreira de dentina reacional obliterando a abertura coronária do canal radicular. Subjacente notou-se, tecido conjuntivo colagenizado com aspecto de normalidade. Em um dos dentes os cortes microscópicos revelaram, na região de um dos cornos pulpares, discreta área de desorganização do tecido conjuntivo, aumento de infiltrado inflamatório e pequena área de necrose tecidual. Os 
resultados deste estudo confirmam que o hidróxido de cálcio pode formar barreira de tecido mineralizado como conseqüência de uma necrose de coagulação inicial.

No terceiro grupo do nosso estudo utilizamos novamente o hidróxido de cálcio, porém desta vez fizemos uso de uma associação de corticosteróide-antibiótico previamente à colocação do mesmo na cavidade. Nosso medicamento de escolha foi o Otosporin ${ }^{\circledR}$ (Farmoquímica S/A), visto sua grande utilização em clínica e pesquisas dentro da Odontologia, sendo sua composição básica hidrocortisona, um conhecido agente antiinflamatório da família dos glicocorticóides, e duas sulfas o sulfato de neomicina e o sulfato de polimixina $\mathrm{B}$, ambos antibióticos de amplo espectro.

A maioria dos relatos encontrados na literatura preconiza a utilização de um curativo de demora por 48 horas, ou seja, quando da utilização desta técnica a pulpotomia deve ser realizada em duas sessões (HOLLAND et al, 1971; SOUZA, HOLLAND e SOUZA, 1995; PERCINOTO, CASTRO e PINTO, 2006). Porém nessa pesquisa fizemos uso do medicamento por 5 minutos sobre o remanescente pulpar, se assemelhando a técnica preconizada quando do uso do formocresol, finalizando a pulpotomia em uma única sessão, o que é de fundamental importância em Odontopediatria. Esse procedimento já havia sido brevemente citado por Estrela (2004), que sugere que o uso de uma medicação tópica por 5 à 10 minutos sobre o remanescente pulpar nos casos de pulpotomia funciona como uma medicação antiinflamatória de reforço, não trazendo malefícios ao dente tratado.

A lesão de cárie constitui um fator de irritação, provocando na polpa um processo inflamatório e, posteriormente, uma alteração degenerativa. Na ausência do tratamento adequado, a inflamação pode progredir a alcançar os tecidos periapicais (ARAÚJO et al., 2004). Compreende-se então que a pulpotomia está indicada nos casos em que o processo inflamatório está limitado à polpa coronária e, a polpa radicular possui ainda condições para estabelecer reparo (ARAÚJO et al., 2004). Soma-se a esse quadro ainda o fato de que o ato cirúrgico do corte da polpa coronária quando da pulpotomia intensifica este processo inflamatório que por fim encontra-se contido por paredes inextensíveis (ESTRELA, 2004).

O componente antiinflamatório do Otosporin $^{\circledR}$ (Farmoquímica S/A) é a hidrocortizona, que apresenta grande eficácia quando empregada nos curativos de demora, auxiliando no reparo da polpa dental (AYDOS, 1985; SAW e THONG, 1993). A hidrocortisona é um glicocosticóide, estes são fármacos antiinflamatórios por excelência, inibindo manifestações precoces e tardias da inflamação como a dor e o edema inicial. Reverte inflamações causadas por agente patógenos, estímulos químicos e estímulos físicos 
(RANG e DALE, 2007), se encaixando corretamente com os estímulos recebidos pela polpa quando da pulpotomia.

O medicamento emprega dois antibióticos da família das sulfas, o primeiro o sulfato de neomicina, um aminoglicosídeo que inibe a síntese protéica bacteriana, atuando contra microorganismos gram-positivos e gram-negativos (GOLDMAN e GILMAN, 2006), estes geralmente encontrados na lesão de cárie e também causadores de posteriores lesões endodônticas como fístulas e abscessos.

A segunda sulfa presente no medicamento é o sulfato de polimixina $\mathrm{B}$, um antibiótico polimixinico com propriedades detergentes, com ação antibacteriana principalmente sobre bacilos gram-negativos (GOLDMAN e GILMAN, 2006), auxiliando a polpa de forma semelhante ao antibiótico anterior no combate das lesões endodonticas causadas por bactérias.

Essa associação de antibióticos tem sua eficácia comprovada em diversas pesquisas clínicas que fizeram uso destas e obtiveram resultados semelhantes aos encontrados em nossa pesquisa de 71,4\% condiz com outros resultados encontrados por Teixeira e Tancredo (1994) e Holland et al. (1998) que obtiveram $89,1 \%$ e $80 \%$ de sucessos clínicos respectivamente. Sendo que em nosso estudo fizemos uso do curativo por 5 minutos, preconizando a pulpotomia em sessão única, o que em odontopediatria é mais indicado, visto que não há necessidade de uma segunda sessão, com nova anestesia e outros procedimentos que podem ser traumáticos à criança.

Portanto o uso da medicação prévia apresenta-se de forma positiva para a pulpotomia de dentes decíduos, pois acarreta um maior índice de sucessos clínicos, havendo uma diminuição das fístulas e abscessos tidos como insucesso, ajudados pela associação antibiótica e somado também ao correto diagnóstico e execução da técnica de pulpotomia.

Estudos de pulpotomias com diferentes materiais capeadores mostram uma variedade de tipos de restaurações dos dentes envolvidos nas pesquisas. Estas restaurações variam de restaurações com cimento à base de óxido de zinco e eugenol reforçado - IRM ${ }^{\circledR}$ (GUELMANN et al., 2002; CHACKO e KURIKOSE, 2006), restaurações com amálgama (PITT FORD et al.,1996; HOLLAND et al., 2001; TZIAFAS et al., 2002; SALAKO et al. 2003; MENEZES et al., 2004; AEINEHCHI et al., 2007), restaurações com resina composta (CHIBINSKI e CZLUSNIAK, 2003; MAROTO et al., 2005; PERCINOTO et al., 2006), restaurações com cimento de ionômero de vidro (DOMINGUEZ et al., 2003; AEINEHCHI et al., 2007; MORETTI et al. 2007; FORNETTI, 2007; MORETTI, 2008) e coroas de aço (EIDELMAN, HOLAN e FUKS, 2001; DEAN et al., 2002;; AGAMY et al., 2004; 
JABBARIFAR, KHADEMI e GHASEMI, 2004; MAROTO et al., 2005; NAIK e HEGDE, 2005; FARSI et al., 2005).

Holan, Fuks e Keltz (2002) relatam que a região cervical de dentes decíduos pulpotomizados apresenta dentina desprovida de prolongamentos odontoblásticos, tornando essa região mais friável e sujeita a trincas e fraturas. Por essa razão, os autores aconselham a colocação de coroa de aço, para que essa região não fique desprotegida. Entretanto, Waterhouse et al. (2000) e Dean et al. (2002) relataram casos de fracasso em pulpotomias associadas a falhas nas coroas de aço. Acreditamos que quando o material restaurador é bem indicado (avaliando quantidade de remanescente dentário, número de faces dentárias envolvidas e higiene bucal da criança) e a técnica realizada de forma adequada, a restauração final apresentará resultado satisfatório. Croll e Killian (1992) recomendam o uso de coroas de aço em todos os dentes decíduos que receberam pulpotomia, independente da quantidade de remanescente dentário e do tempo que esse dente deverá permanecer na cavidade bucal até sua esfoliação. Consideramos essa recomendação excessiva, já que existem no mercado odontológico, materiais adesivos de boa qualidade, fácil manipulação e que proporcionam uma atitude mais conservadora em relação à estrutura dentária.

Neste estudo, realizamos a restauração definitiva na mesma consulta da pulpotomia. Estudos têm demonstrado que restaurações provisórias podem levar a insucessos clínicos e radiográficos, devido a uma possível microinfiltração causada pelo material (GUELMANN et al., 2002). Optamos pela restauração definitiva com cimento de ionômero de vidro modificado por resina - CIVmr (Vitremer ${ }^{\circledR}$ ) por vários fatores: 1 - barreiras dentinárias são mais facilmente visualizadas com CIVmr comparados a coroa de aço; 2 - a realização da pulpotomia e da restauração definitiva em uma única sessão agrada aos responsáveis pela criança, visto que as crianças da amostra, neste estudo, são de nível sócio-econômico baixo, o que dificultaria o retorno das crianças e seus responsáveis para várias consultas; 3 - O CIVmr apresenta propriedades restauradoras muito boas, principalmente para restaurações envolvendo as faces proximais de dentes decíduos, além de atuar de forma preventiva através da liberação de flúor (PEREIRA JÚNIOR, 1997; FORNETTI, 2007, MORETTI, 2008). A opção por um outro material restaurador parece estar relacionada com a cultura dos países e com as filosofias de trabalho de cada instituição de ensino odontológico (FORNETTI, 2007).

Em relação ao quesito restauração adequada, apenas 1 dente do grupo FC e 2 dentes do grupo Hidróxido de cálcio mais antiinflamatório necessitaram de reparo, porém sem interferir no resultado da pulpotomia, sendo que os demais dentes apresentaram sucesso restaurador durante todo o período de avaliação. Acreditamos que a pequena quantidade de 
restaurações reparadas tenha sido decorrência da criteriosa seleção dos casos e do cuidadoso emprego da técnica restauradora, em concordância com estudo de Fornetti (2007) e Moretti (2008). Observando os resultados do presente estudo, no qual as restaurações foram devidamente executadas acreditamos que o uso da medicação antecedendo o hidróxido de cálcio auxiliou no sucesso clínico. Não podemos associar as falhas das pulpotomias com HC ao material restaurador, pois todos os dentes dos 3 grupos avaliados receberam restaurações de Vitremer $^{\circledR}$. Neamatollahi e Tajik (2006) observaram que não se pode atribuir às restaurações, os fracos resultados de um determinado medicamento para pulpotomia, principalmente se essas forem padronizadas e realizadas da mesma maneira nos diferentes grupos.

Com base nos resultados desta pesquisa, propomos a realização de futuros trabalhos utilizando este modelo de estudo, para que possamos ter novas indicações para os diferentes materiais disponíveis no mercado, preconizando as melhores qualidades de cada um, para cada uma de suas indicações, não visando substituir um antigo por um novo, e sim buscando as corretas indicações desses diversos materiais, visando o sucesso da técnica para o melhor conforto do paciente. Sabemos que a procura por soluções e materiais ideais para qualquer área de conhecimento dentro da Odontologia, atualmente deve estar direcionada ao conhecimento e indicação de medicamentos biocompatíveis, visando à ocorrência do processo de reparo e proporcionando regeneração natural e biológica da polpa.

\section{CONSIDERAÇÕES FINAIS}

- O monitoramento radiográfico é essencial após a realização de terapias pulpares, bem como a análise periódica das restaurações dos dentes pulpotomizados.

- Durante a amputação da polpa coronária, se a hemostasia do remanescente pulpar não for alcançada, está indicada pulpectomia do dente.

- Apesar de ser um medicamento de baixo custo e amplamente utilizado em Odontologia com sucesso, diante todos os efeitos adversos, locais e sistêmicos, o emprego do formocresol em pulpotomia deve ser repensado.

- O uso de uma medicação prévia, mesmo que por um curto período de tempo, apresenta bons resultados clínicos, auxiliando a polpa dental no reparo. 


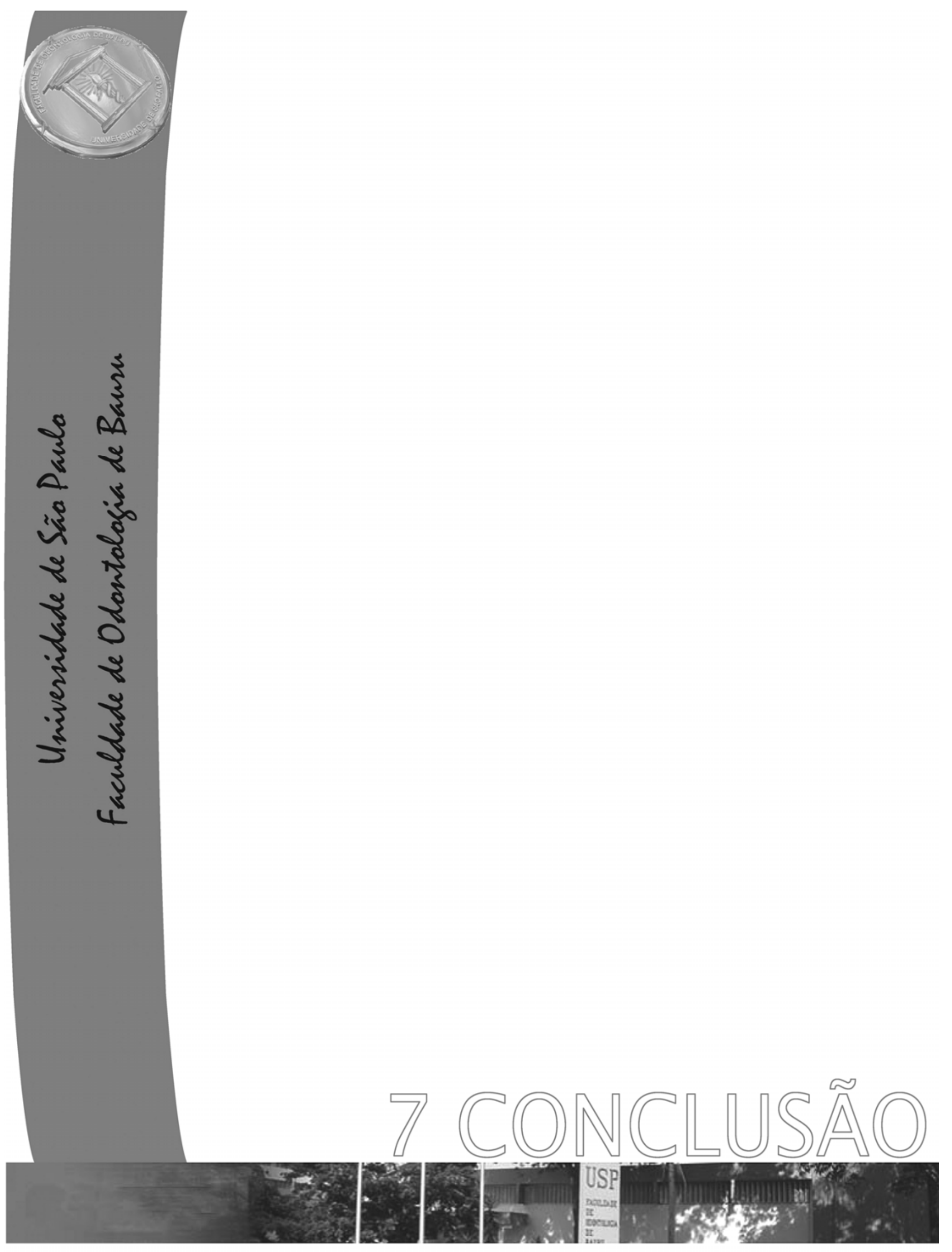




\section{CONCLUIS $\tilde{A} O$}

A análise dos resultados, de acordo com a metodologia proposta, permitiu constatar que comparando os grupos Formocresol com os grupos Hidróxido de cálcio e Hidróxido de cálcio precedido de antiinflamatório, permite que aceitemos a hipótese H1, que existe diferença estatisticamente significante entre os grupos.

Comparando-se os grupos Hidróxido de cálcio e Hidróxido de cálcio precedido de antiinflamatório, a análise dos resultados permite que aceitemos a hipótese nula H0, que não existe diferença estatisticamente significante entre os grupos. 


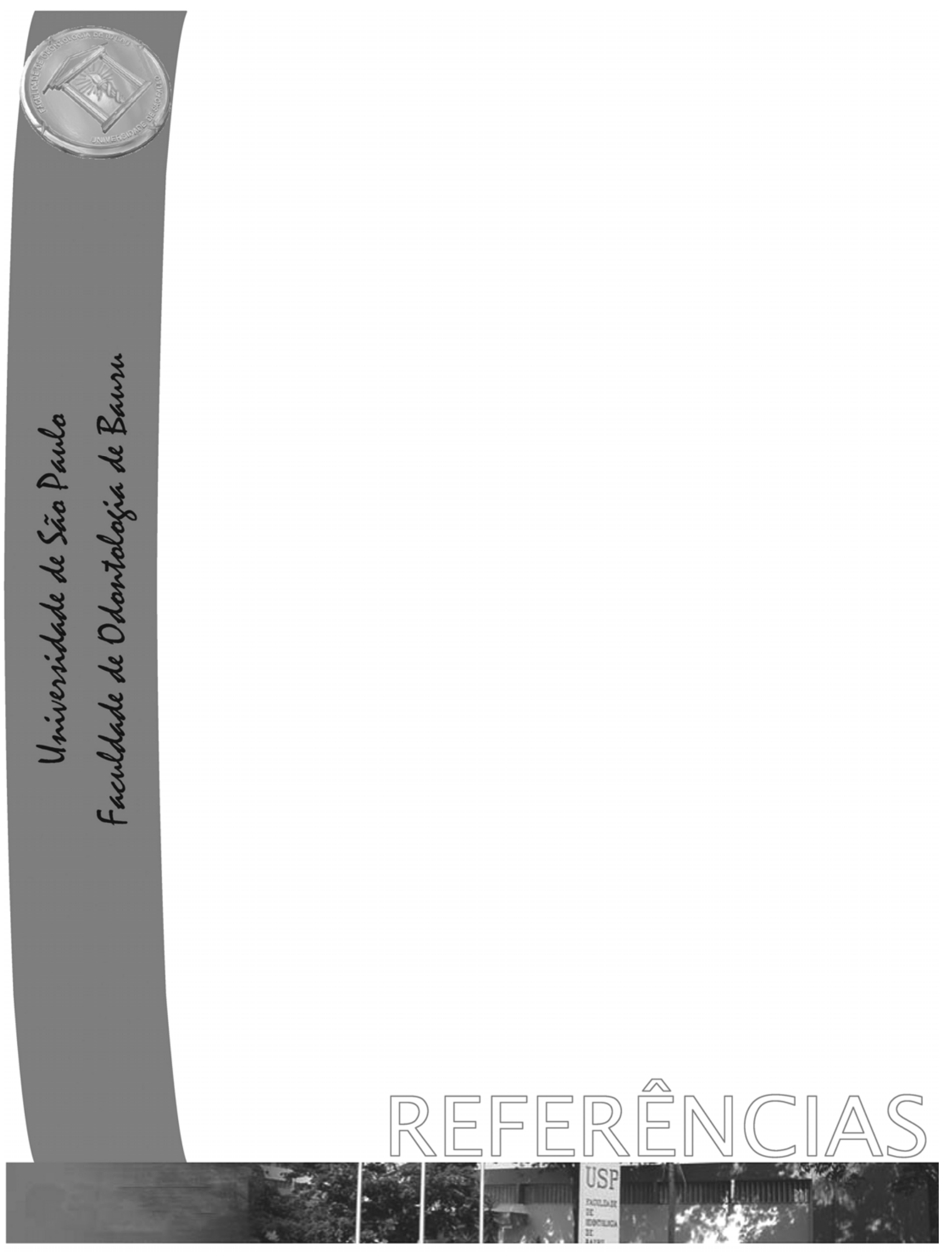




\section{REFEREANCIAS}

AAPD Reference Manual 2005-2006. Guidelines on Pulp Therapy for primary and young permanent teeth. Pediatric Dent 2006;27(7):130-34.

Abdo RCC. Efeitos do formocresol sobre o tecido pulpar e periapical em dentes decíduos de cão (estudo histológico) [dissertação]. Bauru (SP): Faculdade de Odontologia de Bauru, Universidade de São Paulo; 1976.

Aeinehchi M, Dadvand S, Fayazi S, Bayat-Movahed S. Randomized controlled trial of mineral trioxide aggregate and formocresol for pulpotomy in primary molar teeth. Int Endod J. 2007;40(4):261-67.

Aeinehchi M, Eslami B, Ghambariha M, Saffar AS. Mineral trioxide aggregate (MTA) and calcium hydroxide as pulp-capping agents in human teeth: a preliminary report. . Int Endod J. 2003,36:225-231.

Agamy HA, Bakry NS, Mounir MM, Avery DR. Comparison of mineral trioxide aggregate and formocresol as pulp-capping agents in pulpotomized primary teeth. Pediatr Dent. 2004;26(4);302-9.

Albuquerque DS, Gominho LF, Santos RA. Histologic evaluation of pulpotomy performed with ethyl-cyanoacrylate and calcium hydroxide. Braz Oral Res. 2006;20(3):226-30.

Alcure ML. Análise morfológica microscópica da barreira dentinária formada após aplicação do hidróxido de cálcio em polpas dentárias humanas [dissertação]. Bauru (SP): Faculdade de Odontologia de Bauru, Universidade de São Paulo; 2001.

Araújo OMB, Pavarini A, Pinheiro CE, Lima JEO, Abdo RCC. Efeitos do ácido sulfossalicílico-cresol e do formocresol sobre os tecidos pulpar e periapical em dentes decíduos de cão. Odontol Mod. 1987;14(4):6-16.

Assed S. Odontopediatria : bases científicas para a prática clínica. São Paulo : Artes Médicas, 2005

Aydos JH. Tratamento dental da polpa inflamada. Rev. Fac. Odontol. Porto Alegre. 1985;27:153-171.

Briso ALF, Rahal V, Mestrener SR, Dezan Jr E. Biological response of pulps submitted to different capping materials. Braz Oral Res. 2006;20(3):219-25. 
Burnett S, Walker J. Comparison of ferric sulfate, formocresol, and a combination of ferric sulfate/formocresol in primary tooth vital pulpotomies: a retrospective radiographic survey. ASDC J Dent Child. 2002;69(1/2):44-8.

Caicedo R, Abbott PV, Alongi DJ, Alarcon MY. Clinical, radiographic and histological analysis of the effects of mineral trioxide aggregate used in direct pulp capping and pulpotomies of primary teeth. Aust Dent J. 2006;51(4):297-305.

Casas MJ, Kenny DJ, Judd PL, Johnston DH. Do we still need formocresol in pediatric dentistry? J Can Dent Assoc. 2005;71(10):749-51.

Castro A. Current concepts in vital pulpotomies in primary teeth. J Mich Dent Assoc. 2005;87(1):26-8.

Cengiz SB, Batirbaygil Y, Onur MA, Atilla P, Asan E, Altay N, Cehreli ZC. Histological comparison of alendronate, calcium hydroxide and formocresol in amputated rat molar. Dent Traumatol. 2005;21:281-88.

Consolaro A. Reabsorções dentárias nas especialidades clínicas. 2ed. Maringá: Dental Press; 2005.

Cortés O, Fernández J, Boj JR, Canalda C. Effect of Formaldehyde on rat liver in doses used in pulpotomies. J Clin Pediatr Dent 2007;31(3):181-4.

Croll TP, Killian CM. Zinc oxide-eugenol pulpotomy and stainless steel crown restoration of a primary molar. Quintessence Int. 1992;23:383-88.

Curzon MSJ, Duggal MS, Fayle SA, Toumba KJ. Primary pulpotomies. Br Dent J. 2000;189(5):235.

Dean JA, Mack B, Fulkerson BT, Sanders BJ. Comparison of electrosurgical and formocresol pulpotomy procedures in children. Int J Paediatr Dent. 2005;12:177-82.

Dominguez, M.S., Witherspoon, D.E., Gutmann, J.L., Opperman, L.A. Histological and scanning eletron microscopy assessment of various vital pulp-teraphy materials. J Endod. 2003;29(5):324-33.

Eidelman E, Holan G, Fuks AB. Mineral trioxide aggregate vs. formocresol in pulpotomized primary molars: a preliminary report. Pediatr Dent. 2001;23(1):15-8 
Estrela C, Bammann LL, Estrela CRA, Silva RS, Pécora JD. A ntimicrobial and chemical study of MTA, Portland cement, calcium hydroxide paste, sealapex and dycal. Braz Dent J. 2000;11(1):3-9.

Estrela C, Sydney GB, Bammann LL, Felippe Júnior O. Mechanism of action of calcium hydroxide on tissue and bacteria. Braz Dent J. 1995;6(2):85-90.

Estrela C. Ciência Endodôntica - Volume 1 São Paulo : Editora Artes Médicas, 2004

Fadavi S, Anderson AW. A comparison of the pulpal response to freeze-dried bone, calcium hydroxide, and zinc oxide-eugenol in primary teeth in two cynomolgus monkeys. Pediatr Dent. 1996;18(1):52-6.

Faraco Junior IM, Holland R. Response of the pulp of dogs capping with mineral trioxide aggregate or a calcium hydroxide cement. Dent Traumatol.2001;17(4):163-66.

Farooq NS, Coll JA, Kuwabara A, Shelton P. Success rates of formocresol pulpotomy and indirect pulp therapy in the treatment of deep dentinal caries in primary teeth. Pediatr Dent. 2000;22(4):278-86.

Fernandes DSC, Faraco Júnior IM, Kramer PF, Ulian J. Pulpotomias com formocresol em dentes decíduos: avaliação clínica e radiográfica. Rev Gauch Odontol. 2003;51(3):154-61.

Foreman PC, Barnes IE. Review of calcium hydroxide. Int Endod J. 1990;23:283-97

Fornetti APC. Estudo clínico e radiográfico do formocresol de Buckley diluído a 1/5 e do cimento Portland utilizados para pulpotomia em dentes decíduos humanos. [dissertação]. Bauru (SP): Faculdade de Odontologia de Bauru, Universidade de São Paulo; 2007.

Fuks AB, Eidelman E, Cleaton-Jones P, Michaeli Y. Pulp response to ferric sulfate, diluted formocresol and IRM in pulpotomized primary baboon teeth. ASDC J Dent Child. 1997b;64,(4):254-59.

Fuks AB, Holan G, Davis JM, Eidelman E. Ferric sulfate versus dilute formocresol in pulpotomized primary molars: long-term follow-up. Pediatr Dent. 1997a;19(5):327-30.

Fuks AB. Pulp therapy for the primary and young permanent dentitions. Dent Clin North Am. 2000;44(3):571-96. 
Giro EMA, Bausells HII, Percinoto C. Estudo histopatológico em molares decíduos de cães, com polpas vitais, submetidos à pulpotomia e proteção com hidróxido de cálcio, formocresol e glutaraldeído. Rev Odonto UNESP. 1991;20(1):51-62.

Goodman LS, Gilman A. Bases farmacológicas da terapêutica. Rio de Janeiro : Guanabara Koogan, 5 ed. 2006.

Gruythuysen RJM, Smits MFG. Policarboxylate cement as a cavity-sealing material for the calcium hydroxide pulpotomy: A retrospective study. ASDC J Dent Child. 1995;22-4.

Gruythuysen RJM, Weerheijm KL. Calcium hydroxide pulpotomy with a light-cured cavitysealing material after two years. ASDC J Dent Child. 1997;64:251-53.

Guelmann M, Fair J, Turner C, Courts FJ. The success of emergency pulpotomies in primary molars. Pediatr Dent. 2002;24(3):217-20.

Heilig J, Yates J, Siskin, M, McKnight J, Turner J. Calcium hydroxide pulpotomy for primary teeth: a clinical study. J Am Dent Assoc. 1984;108:775-78.

Hingston EJ, Parmar S, Hunter ML. Vital pulpotomy in the primary dentition: attitudes and practices of community dental staff in Wales. Int Endod J. 2007;17:186-91.

Holan G, Eidelman E, Fuks AB. Long-term evaluation of pulpotomy in primary molars using mineral trioxide aggregate or formocresol. Pediatr Dent 2005;27(2):129-35.

Holan G, Fuks AB, Keltz N. Success rate of formocresol pulpotomy in primary molars restored with stainless steel crow vs amalgam. Pediatr Dent. 2002;24(3):212-16.

Holland R, Otoboni Filho JA, Souza V, Nery MJ, Bernabé PFE, Dezan Junior E. Calcium Hydroxide and corticosteroid-antibiotic association as dressings in cases of biopulpectomy. A comparative study in dog's teeth. Bras. Dent. J. 1998;9(2):67-76.

Holland R, Souza V, Milanezi LA, Mello W. Comportamento da polpa após pulpotomia e aplicação tópica de alguns fármacos empregados na terapêutica conservadora. Rev. Bras. Odontol. 1971;167(28):33-36.

Holland R, Souza V, Nery MJ, Otoboni Filho JA, Bernabe PF, Dezan E Jr. Rection of a rat connective tissue to implanted dentin tubes filled with mineral trioxide aggregate or calcium hydroxide. J Endod. 1999;25:161-66. 
Hunter ML, Hunter B. Vital pulpotomy in the primary dentition: attitudes and pratices of specialists in paediatric dentistry practicing in the United Kingdom. Int J Paediatr Dent. 2003;13(4):246-50.

Hunter ML. Premature exfoliation of primary molars related to the use of formocresol in a multivisit pulpotomy technique: a case report. Int J Paediatr Dent. 2003;13(5):362-64.

Huth KC, Paschos E, Hajek-Al-Khatar N, Hollweck R, Crispin A, Hickel R, et al. Effectiveness of 4 pulpotomy techniques - randomized controlled trial. J Dent Res. 2005;84(12):1144-48.

IARC Classifies Formaldheyde as Carcinogenic to Humans. International Agency for Research on Cancer (2004) at:http://www.iarc.fr/ENG/Press_Releases/archives/pr153a.html, accessed on 15 june 2004.

Ibricevic $\mathrm{H}, \mathrm{Al}$-Jame Q. Ferric sulfate as pulpotomy agent in primary teeth: twenty month clinical follow-up. J Clin Pediatr Dent. 2000;24(4):269-72.

Jabbarifar SE, Khademi AA, Ghasemi D. Success rate of formocresol pulpotomy versus mineral trioxide aggregate in human primary molar tooth. J Res Med Sci. 2004;6:55-8.

King SRA, McWhorter AG, Sue Seale N. Concentration of formocresol used by pediatric dentistry in primary tooth pulpotomy. Pediatr Dent. 2002;24(2):157-59.

Kramer PF, Faraco Júnior IM, Feldens CA. Estado atual da terapia pulpar nas universidades brasileiras: pulpotomia e pulpectomia em dentes decíduos. J Bras Odontopediatr Odontol Bebê. 2000;3(13):222-30.

Law DB. An evaluation of vital pulpotomy techinique. J Dent Child. 1956;23:40-4.

Leonardo MR, Utrilla LS, Silva LAB. Avaliação histopatológica dos tecidos periapicais de dentes de cães após biopulpectomia e utilização de diferentes curativos de demora. Rev. Bras. Odontol. 1996;53(5):14-19.

Lewis B. Formaldehyde in dentistry: a review for the millennium. J Clin Pediatr Dent. 1998;22(2):167-77.

Loh A, O’Hoy P, Tran X, Charles R, Hughes A, Kubo K, Messer LB. Evidence-based assessment: Evaluation of the formocresol versus ferric sulfate primary molar pulpotomy. Pediatr Dent. 2004;26:401-9. 
Massara MLA, Noronha JC, Souki BQ, Diniz APV, Navarro CF, Alencar MCB, Reis SAB. A utilização do hidróxido de cálcio em pulpotomias de dentes decíduos. Rev Gauch Odontol.1996;44(5):300-304.

Milnes AR. Persuasive evidence that formocresol use in pediatric dentistry is safe. J Can Dent Assoc. 2006;72(3):247-8f.

Morawa AP, Straffon LH, Han SS, Corpron RE. Clinical evaluation of pulpotomias using dilute formocresol. ASDC J Dent Child. 1975;42(5):360-63.

Moretti AB, Fornetti APC, Oliveira TM, Sakai VT, Santos CF, Machado MA, Abdo RC. The effectiveness of MTA, calcium hydroxide and formocresol for pulpotomies in primary teeth. Int Endod J. 2008

Moretti AB. Estudo clínico, radiográfico e microscópico do formocresol de Buckley diluído a 1/5, hidróxido de cálcio PA e mineral trióxido agregado (MTA) em pulpotomia em dentes decíduos humanos. [dissertação]. Bauru (SP): Faculdade de Odontologia de Bauru, Universidade de São Paulo; 2008.

Myers DR, Shoaf HK, Dirksen TR, Pashley DH, Whitford GM, Reynolds KE. Distribution of ${ }^{14} \mathrm{C}$-formaldehyde after pulpotomy with formocresol. J Am Dent Assoc. 1978;96(5):805-13.

Nadin G, Goel BR, Yeung CA, Glenny AM. Pulp treatment for extensive decay in primary teeth. Cochrane Database Syst Rev. 2003;(1):CD003220.

Neamatollahi H, Tajik A. Comparison of clinical Comparison of clinical and radiographic success rates of pulpotomy molars using Formocresol, Ferric Sulfate and Mineral Trioxide Agregate (MTA). J Dent. 2006; 3, 6-14.

Pashley EL, Myers DR, Pashley DH, Withford GM. Systemic distribuition of $\mathrm{C}^{14}$ formaldehyde from formocresol treated pulpotomy sites. J Dent Res. 1980;59:603-8.

Pastor IMO, Rocha MCBS, Oliveira AMC, Fonseca EA, Pozza WDC. Avaliação clínica e radiográfica da terapia pulpar em molares decíduos. Rev Fac Odontol Univ Fed Bahia. 1986;6:86-101.

Peng L, Ye L, Guo X, Tan H, Zhou X, Wang C, Li R. Evaluation of formocresol versus ferric sulphate primary molar pulpotomy: a systematic review and meta-analysis. Int Endod J. 2007;40:751-57. 
Peng L, Ye L, Tan H, Zhou X. Evaluation of the formocresol versus mineral trioxide aggregate primary molar pulpotomy: a meta-analysis. Oral Surg Oral Med Oral Pathol Oral Radiol Endod. 2006;102(6):40-4.

Percinoto C, Castro AM, Pinto, LMCP. Clinical and radiographic evaluation of pulpotomies employing calcium hydroxide and trioxide mineral aggregate. Gen Dent. 2006;54(4):258-61.

Pereira JC. Tratamentos conservadores da vitalidade pulpar: princípios biológicos e clínicos. Biodonto. 2004;2(3):1-105.

Pereira Júnior ES. Avaliação in vitro da microinfiltração marginal em restaurações de amálgama adesivo tipo Classe II com adesivo dentinário e com cimento de ionômero de vidro. [dissertação]. Bauru (SP): Faculdade de Odontologia de Bauru, Universidade de São Paulo; 1997.

Ralstrom CS. The vital pulpotomy in primary molars. J Mich Dent Assoc. 1999;81(2):40-44.

Rang HP, Dale MM. Farmacologia : H.P. Rang, M.M. Dale, J.M. Ritter. Rio de Janeiro : Guanabara Koogan, 2001

Ranly DM, Garcia-Godoy F. Current and potential pulp therapies for primary and young permanent teeth. J Dent. 2000;28(1):153-61.

Ranly DM. Assessment of the systemic distribution and toxicity of formaldehyde following pulpotomy treatment: part one. ASDC J Dent Child. 1985;52(6):431-34.

Ranly DM. Pulpotomy therapy in primary teeth: new modalities for old rationales. Pediatr Dent. 1994;16(6):403-9.

Rasmussen P, Mjör IA. Calcium hydroxide as an ectopic bone inductor in rats. Scand J Dent Res. 1971;79(1):24-30.

Rivera N, Reyes E, Mazzaoui S, Morón A. Pulpal therapy for primary teeth: formocresol vs electrosurgery - a clinical study. ASDC J Dent Child. 2003;70(1):71-3.

Rocha MJC. O uso do hidróxido de cálcio e do agregado trióxido mineral (MTA) em pulpotomias de dentes decíduos. U F E S Rev Odontol. 2000;2:38-44.

S'Gavenmade EJ. Some biochemical considerations of fixation in endodontics. J Endod. 1975;1:233-7. 
Salako N, Joseph B, Ritwik P, Salonen J, John P, Junaid TA. Comparison of bioactive glass, mineral trioxide aggregate, ferric sulfate and formocresol as pulpotomy agents in rat molars. Dent Traumatol. 2003;19(6):314-20.

Sari S, Aras S, Günhan Ö. The effect of physiological root resorption on the histological structure of primary tooth pulp. J Clin Pediatr Dent. 1999;23:221-25.

Sari S, Sonmez D, Cetinbas T. Comparison of 4 pulpotomy techniques in primary molars: long-term follow-up. Int J Paediatri Dent. 2007;17suppl 1:2.

Scheere SQ, Steinman HR, Cohen JA. A comparative evaluation of three root-end filling materials: an in vitro leakage using Prevotella nigrescens. J Endodon. 2001;27:40-2.

Schröder U. A 2-year follow-up of primary molars pulpotomized with a agente technique and capped with calcium hydroxide. Scand J Dent Res. 1978;86:273-78.

Schuurs AHB, Gruythuysen, RJM, Wesselink PR. Pulp capping with adhesive, resin based composite versus calcium hydroxide: a review. Endod Dent Traumatol. 2000;16:240-50.

Seow WK, Thong YH. Evaluation of the novel anti-inflammatory agent tetradine as a pulpotomy medicament in a canine model. Pediatr. Dent. 1993;15(4):258-266

Smith NL, Seale NS, Nunn ME. Ferric sulfate pulpotomy in primary molars: a retrospective study. Pediatr Dent. 2000;22(3):192-99.

Soares IML. Resposta pulpar ao MTA - Agregado trióxido mineral - comparada ao Hidróxido de cálcio, em pulpotomias. Histológico em cães. [Concurso de Professor Titular] Universidade Federal de Santa Catarina - UFSC;1996).

Souza V, Holland R, Souza RS. Tratamento endodôntico de dentes de cães com polpas vitais em uma ou duas sessões. Influência dos curativos de demora coritcosteróide-antibiótico e hidróxido de cálcio. Rev. Odontol. UNESP. 1995;24(1):47-59

Soviero VM, Souza IPR, Gama FFA. Proteínas dentinogênicas: uma nova tendência para realização de pulpotomias. Rev Bras Odontol. 1998;55(6):314-17.

Srinivasan V, Patchett CL, Waterhouse PJ. Is there life after Buckley's formocresol? Part I - a narrative review of alternative interventions and materials. Int $\mathrm{J}$ Paediatr Dent. 2006;16(2):117-27. 
Strange DM, Seale NS, Nunn ME, Strange M. Outcome of formocresol/ZOE sub-base pulpotomies utilizing alternative radiographic success criteria. Pediatr Dent. 2001;23(4):33136.

Stroppa SC. Analise microscópica da resposta do complexo dentino-pulpar em pulpotomia de dentes decíduos de cães com uso da proteína morfogenética óssea (BMP). [Dissertação] Bauru (SP): Faculdade de Odontologia de Bauru, Universidade de São Paulo;2003.

Teixeira LL, Tancredo N. Aspectos clínicos e radiográficos nas pulpotomias quando do uso de uma associação corticosteróide-antibióticos. Rev. Odontol. Cien. 1994;9(18):57-66.

Tunç ES, Sraloglu I, Sari Saziye, Ömer G. The effect of sodium hypochlorite application on the success of calcium hydroxide pulpotomy in primary teeth. Oral Surg Oral Med Oral Pathol Oral Radiol Endod. 2006;102:e22-e26.

Vargas KG, Packham B. Radiographic success of ferric sulfate and formocresol pulpotomies in relation to early exfoliation. Pediatr Dent. 2005;27(3):233-37.

Vono AZ, Costa AA, Boamorte DC, Keine KC. Avaliação de pulpotomias com formocresol diluído (1:5). Rev Gauch Odontol. 1991;39(2):147-50.

Waterhouse PJ, Nunn JH, Withworth JM. An investigation of the relative efficacy of Buckley's Formocresol and calcium hydroxide in primary molar vital pulp therapy. Br Dent J. 2000a;188(1):32-6.

Waterhouse PJ, Nunn JH, Withworth JM. Primary molars pulp therapy: histological evaluation of failure. Int J Paediatr Dent. 2000b;10(4):313-21.

Waterhouse PJ. Formocresol and alternative primary molar pulpotomy medicaments: a review. Endod Dent Traumatol. 1995;11:157-62.

Yates JA. Barrier formation time in non-vital teeth with open apices. Int Endod J. 1988; 21(5):313-9.

Zarzar PA, Rosenblatt A, Takahashi CS, Takeuchi PL, Costa Júnior LA. Formocresol mutagenicity following primary tooth pulp therapy: an in vivo study. J Dent. 2003;31(7):47985. 


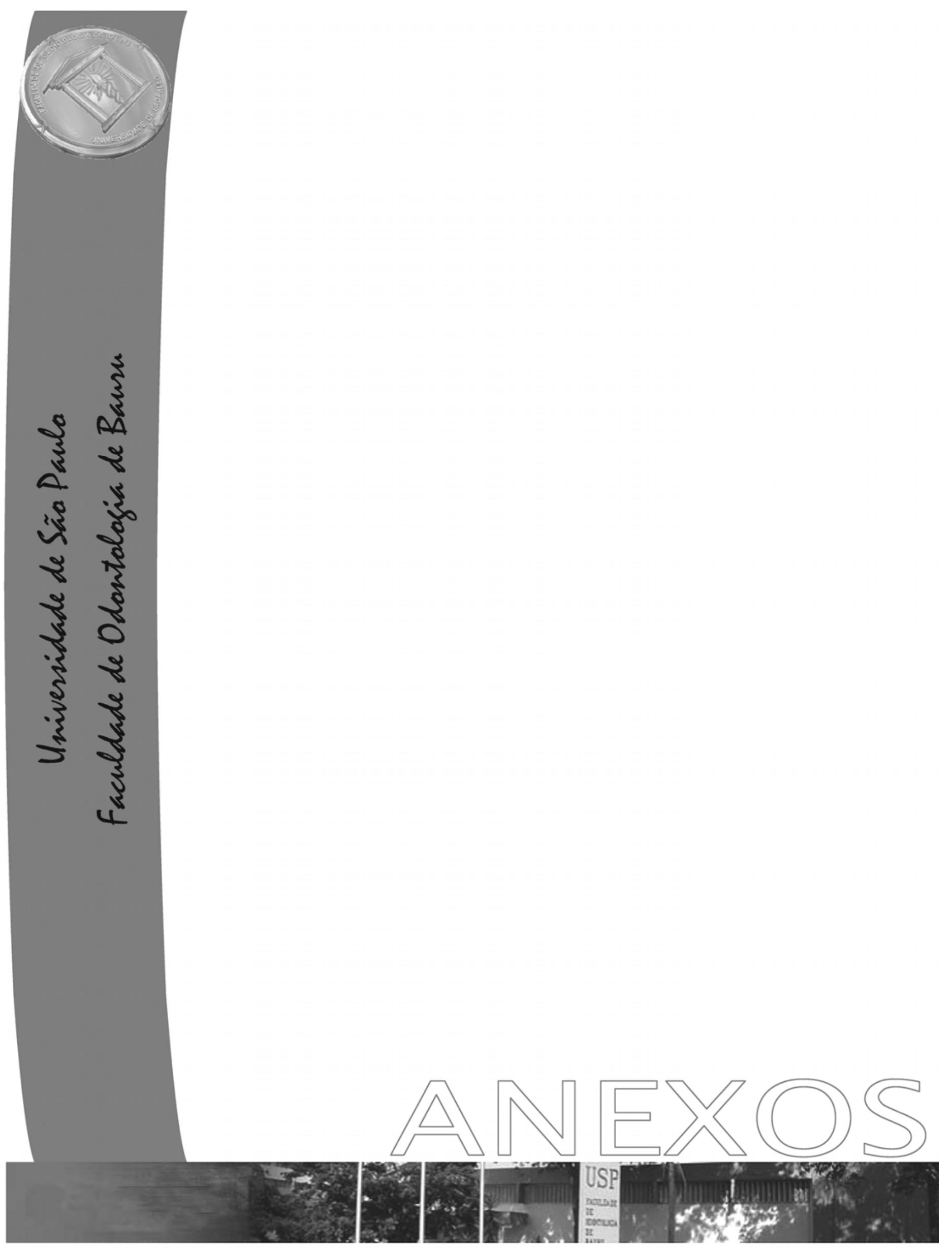




\section{ANEXO 1}

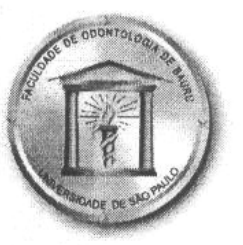

Processo $n^{\circ}$ 62/2007

Bauru, 4 de junho de 2007

\section{Universidade de São Paulo Faculdade de Odontologia de Bauru}

Al. Dr. Octávio Pinheiro Brisolla, 9-75 - Bauru-SP - CEP 17012-901 - C.P. 73 PABX (0XX14)3235-8000 - FAX (0XX14)3223-4679

Comitê de Ética em Pesquisa (14)3235-8356

e-mail: mferrari@,fob.usp.br

Senhor Professor,

O projeto de pesquisa encaminhado a este Comitê de Ética em Pesquisa em Seres Humanos, denominado "Estudo clínico e radiográfico comparativo entre o Formocresol de Buckley a 1/5, Hidróxido de cálcio P.A. e Hidróxido de cálcio P.A. precedido por antiinflamatório para pulpotomia em dentes decíduos humanos.", de autoria de Natalino Lourenço Neto, que será desenvolvido sob sua orientaçăo, foi enviado ao relator para avaliaçăo.

Na reunião de $\mathbf{3 0}$ de maio de 2007 o parecer do relator, aprovando o projeto, foi aceito pelo Comitê, considerando que năo existem infrações éticas pendentes.

Informamos que após o envio do trabalho concluído, este Comitê enviará o parecer final, que será utilizado para publicação do trabalho.

Atenciosamente,

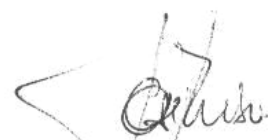

Prof. Dr. José Henrique Rubo Coordenador

Prof. Dr. Ruy César Camargo Abdo

Docente do Departamento de Odontopediatria, Ortodontia e Saúde Coletiva 


\section{ANEXO 2 \\ UNIVERSIDADE DE SÃO PAULO FACULDADE DE ODONTOLOGIA DE BAURU \\ Al.Dr. Octávio Pinheiro Brisolla, 9-75 - Bauru-SP - CEP 17012-901 C.P. 73 \\ PABX (0XX14) 3235-8000- FAX 3223-4679}

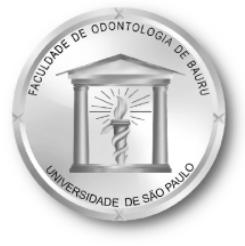

\section{TERMO DE CONSENTIMENTO LIVRE E ESCLARECIDO}

Vimos por meio desta, dar informações e convidá-lo (a) a participar da pesquisa "Estudo clínico e radiográfico comparativo entre o Formocresol de Buckley a 1/5, Hidróxido de cálcio P.A. e Hidróxido de cálcio P.A. precedido por atiinflamatório utilizados para pulpotomia em dentes decíduos humanos." A pulpotomia é um método conservador utilizado para o tratamento de problemas da polpa de dentes de leite. Este tratamento, quando não realizado, pode trazer alguns problemas, como perda precoce do dente, mau posicionamento, além de dificuldade de mastigação e perda de estética. Em decorrência da alta incidência de cárie dentária e da grande possibilidade de contaminação da polpa dos dentes afetados, a pulpotomia, quando corretamente indicada, contribui para a manutenção do dente de leite na cavidade bucal até o aparecimento do dente permanente, mantendo assim suas funções.

Após exame clínico e radiográfico inicial dos dentes indicados para execução do tratamento (podendo ser os primeiros e/ou segundos molares decíduos inferiores, lado direito e/ou esquerdo, de acordo com as necessidades individuais de cada criança), será executado procedimento da pulpotomia, utilizando o medicamento formocresol ou hidróxido de cálcio ou hidróxido de cálcio P.A. precedido de atiinflamatório tópico e em seguida o dente em questão será devidamente restaurado. Em seqüência, a criança será acompanhada durante 6 meses, com controles clínicos e radiográficos nos períodos de três e seis meses após o tratamento. A criança será submetida a 4 tomadas radiográficas se o tratamento for realizado somente em dentes de um dos lados inferiores da face, ou 8 tomadas radiográficas, caso o tratamento seja realizado em dentes nos lados direito e esquerdo inferiores da face.

A seleção do material que será utilizado para realização das pulpotomias ocorrerá de forma aleatória em cada criança. O formocresol será utilizado por ser um medicamento bastante consagrado e de efeito comprovado na literatura científica e o hidróxido de cálcio, precedido ou não por antiinflamatório que apresentam bons resultados em pesquisas de laboratório, necessitam de mais comprovações para que possa trazer os benefícios esperados no tratamento conservador da polpa dos dentes de leite.

Durante o período de realização da pesquisa, caso o tratamento não apresente bons resultados, a criança poderá sentir dor ou então poderá apresentar fístula ou abscesso. Caso isso ocorra o responsável deverá entrar em contato com a clínica de odontopediatria da Universidade de São Paulo pelo telefone 3235-8225, ou então, entrar em contato com o pesquisador, Natalino 
Lourenço Neto através do telefone (14) 3234-4319. Nestes casos, a criança será submetida ao procedimento de pulpectomia (tratamento endodôntico radical) e se este não apresentar resultado satisfatório, será realizada a remoção do dente em questão e, se necessário, colocação de aparelho para manter o espaço até que o dente permanente esteja pronto para nascer.

Caso o responsável pelo voluntário queira apresentar reclamações em relação a sua participação na pesquisa, poderá entrar em contato com o Comitê de Ética em Pesquisa em Seres Humanos, da FOB-USP, pelo endereço Al Octávio Pinheiro Brisolla, nº 9-75 (Sala no prédio da biblioteca, FOB/USP) ou pelo telefone (14) 3235-8356. Além disso, a qualquer momento o responsável pelo voluntário poderá negar-se a continuar participando desta pesquisa, sem quaisquer penalidades.

Pelo presente instrumento que atende às exigências legais, o (a) Sr. (a)

portador (a) da cédula de identidade , responsável pelo (a) menor após leitura minuciosa do TERMO DE

CONSENTIMENTO LIVRE E ESCLARECIDO, devidamente explicada pelos profissionais em seus mínimos detalhes, ciente dos serviços e procedimentos aos quais o (a) menor será submetido (a), não restando quaisquer dúvidas a respeito do lido e explicado, firma seu CONSENTIMENTO LIVRE E ESCLARECIDO concordando em participar da pesquisa proposta.

Fica claro que o sujeito da pesquisa ou seu representante legal, pode a qualquer momento retirar seu CONSENTIMENTO LIVRE E ESCLARECIDO e deixar de participar desta pesquisa e ciente de que todas as informações prestadas tornarão-se confidenciais e guardadas por força de sigilo profissional (Art. $9^{\circ}$ do Código de Ética Odontológica).

Por estar entendido e de acordo assinam o presente termo.

Bauru, de de 20

Natalino Lourenço Neto

Pesquisador 


\section{ANEXO 3}

Estudo clínico e radiográfico comparativo entre o Formocresol de Buckley a 1/5, Hidróxido de cálcio P.A. e Hidróxido de cálcio P.A. precedido por antiinflamatório para pulpotomia em dentes decíduos humanos.

\section{Avaliação Clínica e Radiográfica}

Nome do paciente:-

Data de nascimento: / /

Data do procedimento:-

Dente:-

Material:-

1 a Avaliação - $\underline{3}$ meses

\begin{tabular}{|l|l|l|l|}
\hline Clínico & Sim ou não & Radiográfico & Sim ou não \\
\hline Sintomatologia & & Reabsorção interna & \\
\hline Mobilidade & & Comprometimento de furca & \\
\hline Sensibilidade à percussão & & $\begin{array}{l}\text { Áreas inter-radiculares } \\
\text { radiolúcidas }\end{array}$ & \\
\hline Presença de fístula/abscesso & & Calcificações pulpares & \\
\hline Odor fétido & & Formação de Barreira Dentinaria & \\
\hline Alteração de cor & & Lesão Periapical & \\
\hline
\end{tabular}

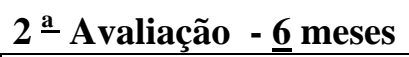

\begin{tabular}{|l|l|l|l|}
\hline Clínico & Sim ou não & Radiográfico & Sim ou não \\
\hline Sintomatologia & & Reabsorção interna & \\
\hline Mobilidade & & Comprometimento de furca & \\
\hline Sensibilidade à percussão & & $\begin{array}{l}\text { Áreas inter-radiculares } \\
\text { radiolúcidas }\end{array}$ & \\
\hline Presença de fístula & Calcificações pulpares & \\
\hline Odor fétido & & Formação de Barreira Dentinaria & \\
\hline Alteração de cor & & Lesão Perapical & \\
\hline
\end{tabular}

3 a Avaliação - $\underline{12}$ meses

\begin{tabular}{|l|l|l|l|}
\hline Clínico & Sim ou não & Radiográfico & Sim ou não \\
\hline Sintomatologia & & Reabsorção interna & \\
\hline Mobilidade & & Comprometimento de furca & \\
\hline Sensibilidade à percussão & & $\begin{array}{l}\text { Áreas inter-radiculares } \\
\text { radiolúcidas }\end{array}$ & \\
\hline Presença de fístula & & Calcificações pulpares & \\
\hline Odor fétido & & Formação de Barreira Dentinaria & \\
\hline Alteração de cor & & Lesão Perapical & \\
\hline
\end{tabular}

